HARVARD UNIVERSITY.

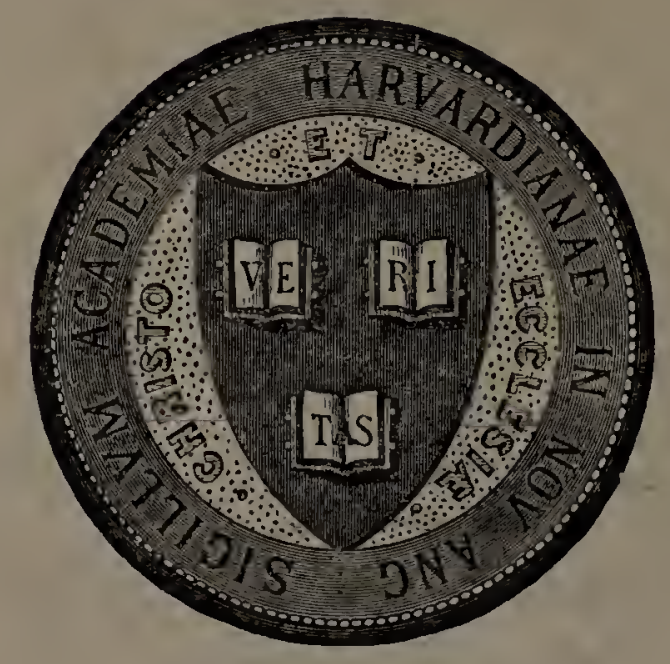

LIBRARY

OF THE

MUSEUM OF COMPARATIVE ZOÖLOGY. 39982

GIFT OF

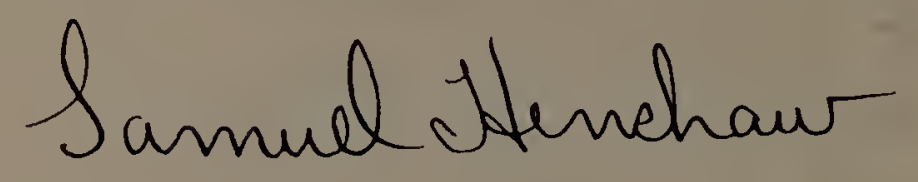

August 2, 1913 . 
39,982

\section{SOME OHIO BIRDS}

\section{OHIO}

\section{Agricultural Experiment Station}

WOOSTER, OHIO, U. S. A., AUGUS'r, $191 z$.

\section{BULLETIN 250}

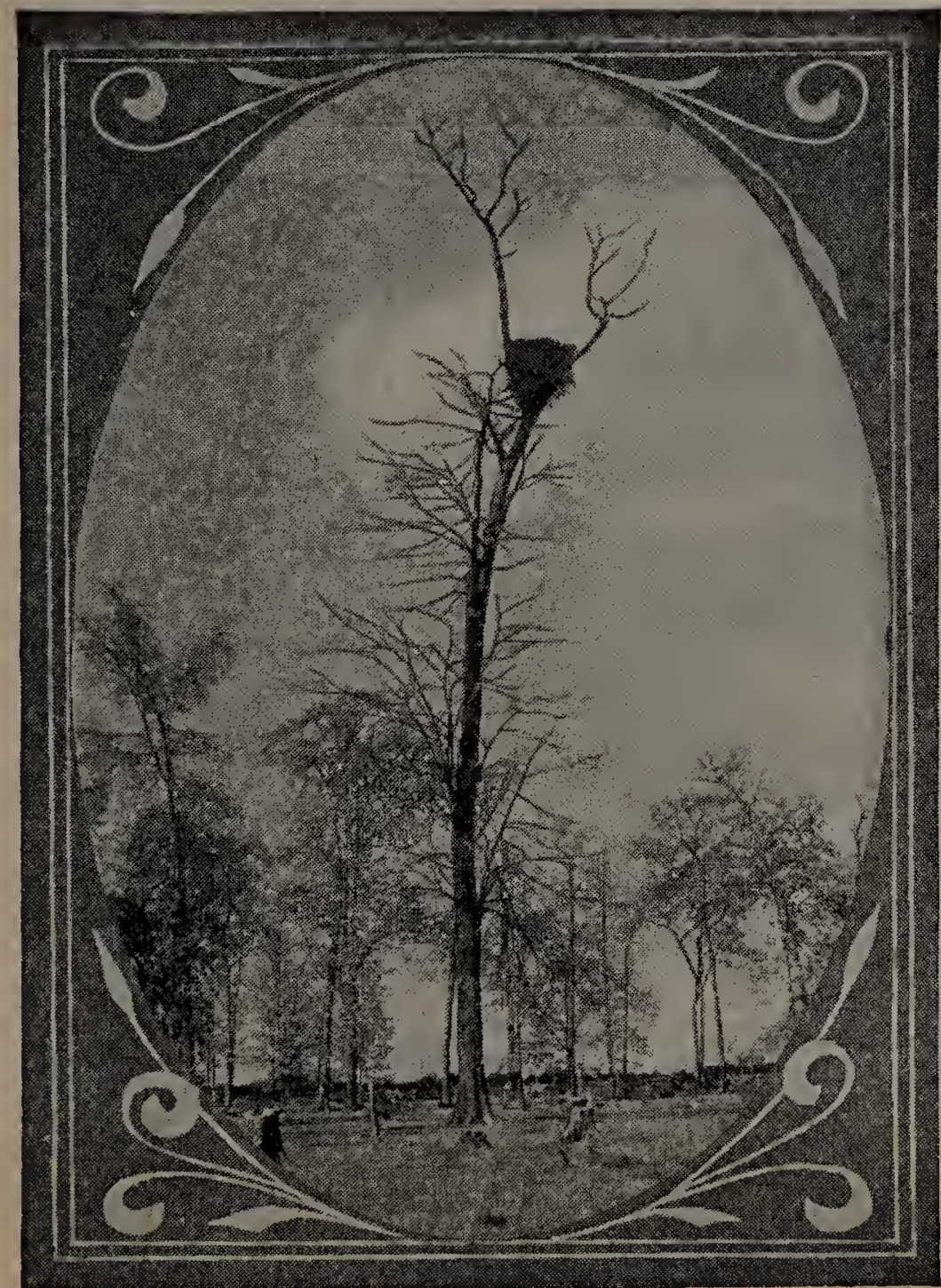

EAGLE'S NEST; GYPSUM, 0.

Photo by $\mathcal{F} . L$. King.

The Bulletins of this Station are sent free to all residents of the State who request them. When a change of address is desired, both the old and the new address should be given. All correspondence should be addressed to EXPERIMENT STATION, Wooster, Ohio 


\section{OHIO AGRICULTURAL EXPERIMENT STATION}

\section{BOARD OF CONTROL}

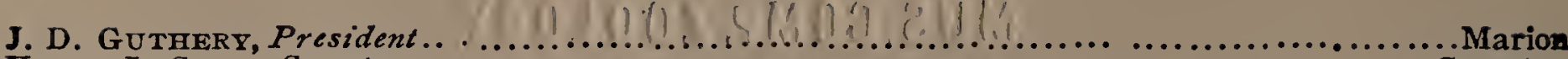

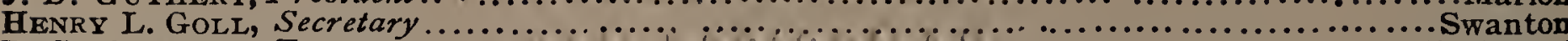

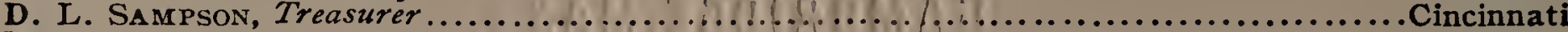

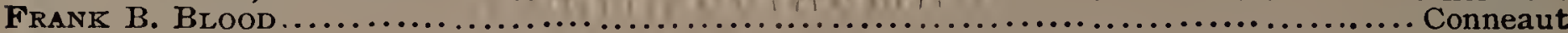

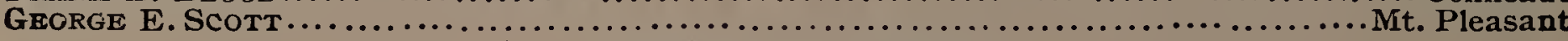

\section{STATION STAFF}

Charles E. Thorne, M. S. A., Director

\section{DEPARTMENTAL ORGANIZATION}

\section{Administration}

The Director, Chzef

WILliam H. KRAMER, Bursar

D. W. Galehouse, Assistant

DORA Ellis, Mailing Clerk

GLENN HALL, Engineer

W. P. BeEching, Photographer

W. K. GREenBANK, Librarian

Agronomy

C. G. WILliams, Chief

F. A. Welton, B. S., Assistant

Wrlliam Holmes, Farm Manager

C. A. Patton, Assistant

E. C. Morr, Office Assistant

C. H. LeBold, Asst. For eman

Animal Husbandry

B. E. Carmichael, B. S., Chief

J. W. HAM MOND, M. S., Assistant .

GEO. R. EASTwOOD, B. S., Assistant

DoN C. Mote, M. S., Assistant

Anthony RUSS, Herdsman

E. C. Schwan, Shepherd (Carpenter)

W. J. Buss, Office Assistant

Botany

A. D. Selbr, B. S., Chief

TRUE HoUSER, B.S., Assistant (Germantown)

F. K. MathIs, Office Assistant

E. L. NrxoN, B. S., Assistant

Chemistry

J. W. A mes, M. S., Chief

E. W. GAITHER, B. S., Assistant

GEO. E. BOLTZ, B. S., Assistant

J. A. Stenrus, B. S., Assistant

GeORge MCClure, Assistant

Climatology

J. WARREN SMrTH, Chief 1

C. A. Patton, Observer

Cooperation 2

L. H. GODDARD, C. E., Chref

M. O. BugBy, B. S., Assistant

W. A. Lloyd, B. S., Assistant

W. M. CooK, A. B., Assistant

W. L. Elser, B. S., Assistant

C. W. Montgomery, Assistant

F. N. Meeker, B. S., Assistant

G. B. Maynadrer, Assistant

A. L. Hrggrns, B. S. Assistant

H. W. HAWTHORNE, Assistant

H. P. Mrller, B. S., County Agent

ORPHA M. KOONTZ, Office Assistant

Dairying

C. C. HAYDEN, M. S., Chief

A. E. Pekrins, M. S., Assistant

T. R. MrDDAUGH, Office Assistant

R. D. GEORGE, Herdsman

W. N. MCMrLLAN, Herdsman (Lancaster)

M. C. MeEkER, Herdsman (Miansfield) 4

Thomas Bayes, Herdsmam (Orient) 5
Entomology

H. A. Gossard, M. S., Chief

J. S. HouSER, M. S. A., Associate

W. H. GoodwrN, B. S., Assistant

R. D. Whitmarsh, M. S., Assistant

J. L. Krng, Assistant

Forestry

EdMund Secrest, B. S., Chief

J. J. CR UMLEY, Ph. D., Assistant

A. E. TAYLOR, Assistant

D. E. SNYDER, Office Assistant

Horticulture

W. J: Green, Vice Director, Chref

F. H. Ballou, Assistant

E. J. RigGs, B. S., Assistant

PaUl Thayer, B. S., Assistant

Victor Herron, Assistant

C. W. Ellenwood, Office Assistant

ORA Flack, Foreman of Orchards

W. E. BONTRAGer, Foreman of Grounds

C. G. LAPER, Foreman of Greenhouses

Nutrition

E. B. Forbes, Ph. D., Chief

A. F. D. W Ussow, M. S., Assistant

M. HeLen KeITH, A. M., Assistant

F. M. BEEgLE, B. S., Assistant

J. E. Mensching, Assistant

Charles M. Frrtz, B. S., Assistant

Soils

The Director, Chief

GEORGe N. Coffer, Ph. D., Assoczate

Charles McIntire, Assistant

E. R. Allen, M. S., Assistant

H. Foley Tuttle, M. S., Assistant

\section{DISTRICT EXPERIMENT FARMS}

Northeastern Test-Farm, Strongsville. EDWARD MohN, Resident Manager

Southwestern Test-Farm, Germantown. HeNRy M. WACHTER, Resident Manager

Southeastern Test-Farm, Carpenter. H. D. LEWIS, Resident Manager Lewis Schultz, Horticultural Foreman

Northwestern Test-Farm, Findlay. JoHN A. Sutton, Resident Manager

\section{COUNTY EXPERIMENT FARMS}

Western District

Charles McInTIRe, Agent in charge

Troy

Victor Herron, Hort. Assisianı College Hill

Miami County Experiment Farm, Troy JOSEPH BRown, Resident Manager

Paulding County Experiment Farm, Paulding A. E. Smith, Resident Manager

Clermont County Experiment Farm, Owensville Howard ElliotT, Resident Manager

Hamilton County Experiment Farm, Mt. Healthy P. C. Herron, Resident Manager

IIn cooperation with U. S. Weather Service.

In cooperation with Bureau of Plant Industry, U. S. Department of Agriculture.

'In cooperation with Boys' Indust.ial School. '4In cooperation with Ohio State Reformatory.

In cooperation with Ohio Institution for Feeble Minded Youth. 


\section{BULLETIN}

OF THE

\section{Ohio Agricultural Experiment Station}

NUMBER 250

Adgust, 1912

\section{SONE OHIO BIRDS}

BY H. A. GOSSARD AND SCOTT G. HARRY

\section{INTRODUCTION}

In 1896 the Ohio Agricultural Experiment Station published a technical bulletin "The Birdr of Wayne County" by Mr. H. C. Oberholser. In this pamphlet atiention was given to all the species that had, up to that time, been recorded as having been seen in the county. Notes upon food and nesting habits, together with descriptive matter and migration records were also included in the work. Subsequent to this publication nothing regarding birds has been distributed by the Station, except some compiled notes in Bulletins 164 and 198, also some migration records collected by the junior author and by Mr. A. I. Good for a series of seasons preceding 1908, these also being included in Bulletin 198. These few and abbreviated papers were sufficient, however, to start a stream of inquiries for information, which stili continue, and which, for convenience sake, both for our constituents and for ourselves, the Station authorities bave deemed best sho:1ld be answered in the present paper. When the senior arthor was requested to become responsible for the preparation of this work, he was much gratified to be able to enlist at the time of its inception the help of the junior writer who, while employed for the past several years in the Departments of Horticulture and Forestry, has, as a diversion, made a special study of bird habits and of bird migration. The heavier part of the work in getting ready the manuscript has devolved upon the latter, and the migration records for a period of eleven years have been collected by him, working independently of any direction save his own initiative. While, 
therefore, much of the matter contained in the general portion of the bulletin is to be found in substance in the writings of others, there is also a considerable part of this which summarizes the results of original observation.

Careful scrutiny of the migration records discloses that twentyone species have been added to the preliminary Oberholser list, classified as follows:

Casual or accidental*

Double-crested Cormorant

Snowy Egret

Hoyt's Horned Lark

Pine Grosbeak

Winter Visitors

Pine Siskin

Summer Residents

Lark Sparrow

Northern Parula Warbler

Kentucky Warbler

Bewick's Wren

Transient Visitors

Holboell's Grebe

Ringed-billed Gull

Black-crowned Night Heron

Least Sand piper

Blue-headed Vireo

Golden-winged Warbler

Nashville Warbler

Prairie Warbler

Hooded Warbler

Palm Warbler

Water Thrush

Canada Warbler

Practically all of these were identified in life with a prisn binocular glass by the junior author, or else the skins of killed specimens were used for identification. The locality from which such dead specimens came was in every case established by an interview with the parties who shot them. Hoyt's Horned Lark was admitted

*We have not included in this list a somewhat uncertain record of the Yellow-throated Warble r. What certainly appeared to be this species was observed by the junior author in an orchard north of Wooster, May 13, 1902. The examination was made through a binocular glass at a distance not to exceed 20 feet. While the observer was quite certain of the idenitification, it has not been included in the list since the skin was not secured. 
to the list upon authority of Oberholser, (Proceedings of U. S. National Museum, Vol. XXIV, No. 1271, 812.) The Palm Warbler was admitted upon the authority of Mr. A. I. Good. This species was observed by the junior writer to be plentiful in Ashland county very near to the boundary line of Wayne in the spring of 1903. Holboell's Grebe is admitted upon authority of Mr. R. W. Glenn, who examined and identified a specimen shot on Wooster Reservoir in 1904. The Nashville Warbler is likewise listed upon authority of Mr. Glenn, who shot and identified the specimen. To these and others who have assisted with various data we hereby express our thanks.

The migration dates or resident periods have been extended either earlier or later than former records for about sixty species.

\section{ECONOMIC FUNCTIONS OF BIRDS}

The character of the food eaten by birds, insects, or animals decides their economic status. When the food of a bird consists of insects or mammals injurious to crops, forest trees, or to other. property, that bird is of service to man and, therefore, beneficial. A bird, animal, or insect, is beneficial or injurious to the degree that harmful or useful forms are eaten or destroyed by it.

Their mode of locomotion, together with their structural fitness for their natural functions, make birds a very important economic factor in the animal kingdom, especially from the standpoint of their usefulness to man. Endowed with the power of flight, they speedily cover great distances, thus controlling outbreaks of insects or rodents in widely separated sections of country.

Aside from their destruction of noxious insects and animals, birds are useful as weed-seed destroyers, also as scavengers, and again are instrumental in the dissemination of the seeds of trees and other plants. The place of birds in nature is entirely unique. Each species performs a service which no other can so well accomplish; each is structurally modified for the particular work nature demands of it. These modifications, in such species as the Cross-bill, Wry-bill, Spoon-bill, and others are very marked, giving them an unnatural and grotesque appearance, even to the point of deformity. In other species, various structural modifications in feet, legs, wings, necks, or other parts are found, but always for the purpose of facilitating the specific task which each must perform.

So complex are the food habits of birds, that they are little understood, and probably never will be fully known. A species may be useful part of the year, and harmful at certain other times; an active destroyer of insects within the breeding range may become a pillager 
of grain during migrations. Certain species, highly beneficial in normal numbers, become destructive when their numbers are greatly increased. The whole economic problem hinges on the balance that can be preserved in nature. An increased food supply would tend to increase the number of birds feeding thereon; when the supply is materially decreased, the birds must look elsewhere for food, and this may result in their becoming destructive.

From the beginning of time, the organic forces of nature have been engaged in constant conflict, each against the other, but maintaining, on the average, a stable balance until the advent of civilized man. In our own country this equilibrium was preserved until the Pilgrim Fathers began to hew homes out of the virgin forest. Fields of maize and wheat supplanted the forest, affording an abundant supply of juicy, tender food to many insects that formerly were dependent upon the forest. The destruction of the forest has caused a steady decrease in the numbers of birds, dependent thereon for protection, food, and nesting sites; this, with the destruction of many birds for food or other purposes, has greatly reduced this natural check on insect life. Many species have adapted their manner of living to the changed conditions, some of which find present conditions even more favorable than those prevailing formerly. Other species, native to the western plains have, since the settling of the country, extended their ranges eastward.

\section{AS DESTROYERS OF INSECTS}

The loss to cultivated crops, through insect ravages, is stupendous. Such loss to cereal crops, animal products, and farm woodlots has been estimated at ten percent of the value, and twenty percent has been computed for truck crops and fruits. (Marlatt).

Of the Field. A few of the important insects detrimental to Ohio field crops are the Colorado potato beetle, the white grub of the May beetle, chinch bug, army worm, wire worm, grasshoppers, crickets, and various cutworms. In normal numbers, their injury is not so apparent, but when conditions are favorable for their increase, any one of these may become a serious pest. Spraying is practicable for but few field crops, so help must be looked for from other sources. At such times, birds must be rated as among man's most important allies.

Cutworms are among the most destructive of larvae, sometimes almost totally destroying a crop, Many species of birds aid in their destruction, and for a few species these insects, when obtainable, constitute a large part of their food. The white grub of the May beetle, on account of its subterranean habits. is difficult to combat. 
It is very destructive to strawberries, grass lands, cereal crops, and root crops; in fact, no plant is safe against its attacks. It is for this grub that the despised Blackbird or Bronzed Grackle is looking, when walking in the freshly turned furrow. Several species of birds feed upon either the larvae or the adults, or both. The Colorado potato beetle exacts a heavy toll from the potato growers each season. But few birds eat this pest, the most important being the Rosebreasted Grosbeak, Night Hawk, and Bob-white, all of which destroy them in larger or smaller numbers. Chinch bugs, army worms, wire worms, grasshoppers, and crickets are all more or less destructive to grass and to cereal crops, and are included in the diet of birds feeding among these crops. Crows, some of the Hawks, the Blackbirds, Finches and Sparrows, Doves, Bob-whites, and some of the Plovers and Sandpipers are essentially birds of the field; some resort thither to feed, while others both feed and nest in grain and grass lands.

In Orchard. There is no well defined line of distinction between birds of the field and those of the orchard, or between these and the woodland dwellers. Certain families may be represented in one or all of these three groups. Certain species are never found except in woodland while others occur in open fields only.

The more important among injurious insects of the orchard are plant lice, caterpillars, codling worms, bark and wood-boring beetles and scale insects. The beginner in fruit growing soon learns to know these forms through the opposition they offer to the successful culture of fruit. Some species among the Thrushes, Warblers, Vireos, Finches, Sparrows, Fly-catchers and Woodpeckers constitute a principal check on insect life in orchard and garden. So inseparable has the association become between the Robin, Bluebird, Chippy and Wren with the orchard and garden, that the mention of the one brings the memory of the other.

Of the Woodland. Many insects are to be found in or on our native trees, but comparatively few of them are of great economic importance. Among the most destructive are some of the saw-flies, bark-beetles, bark or wood borers, caterpillars, plant lice and a few of the scale insects. Any of these insects may become a menace to native trees or shrubs, used as ornamentals.

Man may be able to control insect life in gat den and field by spraying, fall ploughing and subjecting the land to freezing, by rotation of crops, and in various other ways; or, by spraying, fumigating, and similar methods he may hold in check the insect enemies of orchard, park and shade trees. Our forests are, however, in the main, dependent upon natural means of protection against injurious 
insects, and except for the birds, it may be doubted if there would be any forests. The benefit is mutual; the forest furnishes for the birds food, nesting sites and shelter from the elements and gets its recompense through their destruction of noxious animals and insects.

\section{PLANTING SEEDS}

Birds play an important part in the distributing of plants. Water fowl, such as herons and shore birds, may carry small seeds for long distances embedded in mud which adheres to their feet. Barren islands which of necessity must remain such, without outside intervention, are, through the agency of birds, fertilized and planted.

The fruit-eating birds are among the most valuable of the tree planters, distributing seeds far and wide. Crows, Jays, Woodpeckers, and other birds, as well as squirrels, lay up a store of nuts, acorns and tree seeds for use during winter, many of which are dropped, forgotten, or otherwise escape from their owners. These seeds germinate and if the conditions are favorable, will grow in to sturdy seedlings. Wherever hardwood trees succeed pines, or vice versa, the birds are very instrumental in bringing about the succession or rotation.

\section{AS DESTROYERS OF RODENTS AND NOXIOUS ANIMALS CHARACTER OF BIRDLESS COUNTRIES}

Field mice, moles, shrews, squirrels, rabbits, marmots, and many other rodents add to the destruction caused by insects. They abound in forest, field, and orchard, and about the abodes of man, even seeking the shelter and protection of his roof and living upon the fruits of his labor. Probably through no means that human ingenuity is or will be able to devise can the scourge of noxious rodents be effectually checked. The Raptors-the Hawks and Owls, constitute a natural and probably the most important check on the abnormal increase of these devastating animals. Plagues of rodents have been recorded from ancient times to the present day. At whatever time or place these have occurred, investigation has disclosed that they followed a reduction in the numbers of the rapacious birds that normally ranged over the stricken areas. Nevada suffered such a plague during 1907-1908 which resulted in great loss to the ranchmen. Among the birds that flocked to the infested region to feed on the animals were Hawks, Owls, Gulls, Crows, Ravens, Herons, and Shrikes. Such food habits indicate not only an emergency value for these species, but with almost equal certainty prove their constant, though unrecognized worth. Thus, many of the hawks were shot by men who were trying to suppress the plague by means of poison.*

*Farmers Bulletin U. S. D. A. No. 352. 
Just so long as the farmer destroys such valuable birds, just so long will his crops suffer through the ravages of destructive rodents and insects. Knowing the danger invited by the destruction of useful birds, the husbandman should demand their protection. A few species are in part or wholly detrimental, but it is the safer plan, where one does not know their specific value, to let the harmful live, rather than, through ignorance, to kill the beneficial. As has just been suggested, the increase of rodents, insects, and other injurious animals is but a natural consequence following the reduction in numbers of their natural enemies. It is likewise true that the decrease of vegetation is proportional to the increase of insects and rodents dependent thereon for food. The corollary follows that a country without birds would become a desolate waste, unable to support life. It has been conjectured by a careful student of the question that, if birds were swept from the earth, all higher forms of vegetable and animal life would be impossible after eight years.

\section{AS DESTROYERS OF WEED SEEDS}

Another office in which birds must be considered as of economic value to man is in the capacity of seed destroyers. During winter, when insects and other food are difficult to procure, great quantities of weed seeds are destroyed. Preeminent among the seed eaters are the Sparrows and Finches. These birds are equipped with strong bills to crush, and with muscular gizzards to grind hard seeds. This class of birds is not so migratory as those depending upon insects for food, and is well represented among our winter birds. Insects are also destroyed in varying numbers, the maximum of such consumption being reached during the time the young are in the nest, as the nestlings are almost entirely insectivorous. In agricultural communities the value of birds of this class can hardly be over estimated. At the approach of winter, great flocks of Juncos or Snowbirds and Tree Sparrows take up their residence in weedy fields, adding cheer to the winter landscape and, at the same time, they aid the tiller of the soil in his battle with the weeds. The Meadowlark, Bob-white, Bobolink and Mourning Dove are valuable weed seed destroyers. 'Two of these birds are on the game list and a third was also until within recent years. When the economic value of the Bob-white and the Mourning Dove is fully comprehended by those directly benefitted, their protection will be assured. 


\section{AS CONSUMERS OF GRAIN, VALUABLE INSECTS, FRUIT, BUDS, EGGS, AND YOUNG OF OTHER BIRDS}

It is true that birds eat more or less grain, some beneficial insects and fruit; also, that a few species devour the eggs and young of useful birds, and that many of them may be in other ways somewhat detrimental; but the balance for good is in favor of the class of birds, considered as a whole, and the same favorable balance holds true for most of our native species, considered separately. The larger percentage of the grain eaten by most species is unquestionably waste grain, gleaned from the ground after harvest. The chief insects useful to man are bees, those of parasitic habits, and various others, such as are instrumental in the fertilization of blossoms. More or less loss is occasioned because of such valuable insects as these being eaten by birds, but this is insignificant compared with the offsetting gain obtained by the destruction of the myriads of harmful forms which constitute the usual food of so many birds. Beneficial insects, if too numerous, sometimes become a source of injury, so it is possible that the birds are merely maintaining the proper balance in numbers, even of these.

A few species are accused of doing injury to buds of truit or ornamental trees; but ordinarily, little injury is likely to occur through this cause, since nature produces many times the number of buds that can possibly mature. Late winter and early spring is the time when buds are most likely to be sought because of a scarcity of other food. If not destroyed in great quantity, the plucking of buds may result in actual benefit, the effect resulting the same as pruning. Some of the Finches and the Grosbeaks sometimes eat buds, but it is doubtful if serious harm ever results. The Ruffed Grouse is forced to eat buds during winter, when the ground is covered with snow, but little economic importance need be attached to this, because the buds are of shrubs and trees of the forest, and the loss of some buds from such trees cannot be considered serious.

A serious accusation against some otherwise beneficial birds is that of nest-robbing. Crows, Jays and Blackbirds are guilty of this practice, but to what extent is not known. The Blue Jay is a noted pilferer of the eggs of other birds and sometimes takes the callow young when eggs are not to be had. It is altogether likely that certain individuals are addicted to this pernicious habit, and not the whole species. If such is the case, the killing of such individuals would be justifiable and advisable, while their well behaved brothers should be spared. 


\section{ATTRACTING THE BIRDS AND ENCOURAGING THEIR INCREASE \\ FEEDING, ESPECIALLY IN WINTER}

There are many causes for the diminution in the numbers of our native birds. Man is responsible for it, either directly or indirectly, to a great extent. The cutting of forests; clearing of shrubbery; mowing of fence rows; draining of swamps; tilling of the land; shooting for food, for profit or sport; destruction of those that injure crops; and burning over land, all have a bearing on the subject. So likewise does the erection of light houses, telephone wires, and wire fences; also, the introduction of bird destroying animals. Nature also limits the multiplication of birds as well as of other creatures. Over some of nature's checks man has no control, such as the elements, and it is little less than miraculous that so many birds, young and old, escape death. Entire bands of migrating birds are sometimes overcome by storms and swept into the sea. Many starve or freeze to death.

Birds are not al ways the cheery, light-hearted creatures of summer. Sometimes conditions are most adverse, and for days at a time food is unobtainable. At such times, many a bird that otherwise might starve or freeze to death may be saved by feeding. The time and expense required to maintain a food shelf for the birds is trivial, but the good resulting is very great. The food shelf should be placed, if possible, in a sheltered situation, with the southern side exposed, and well out of reach of cats. A south window is a good place and permits of observation from within. Suet, cracked nuts, seeds, grains and crumbs should be furnished in goodly quantity. When the ground is frozen and no snow is in evidence, warm water is a necessity. A suet ball may be suspended from a branch or under the porch for the Chickadees, Nuthatches and Downy Woodpeckers. This is made by winding a piece of suet with cord to keep it from falling to pieces and suspending it by a piece of strong twine, eight or ten inches long. House Sparrows seldom, if ever, bother a piece of suet so fixed, but more or less trouble will be caused by the Sparrows driving other birds from the food shelf. For those birds that will not come to the food shelf, scatter a quantity of the fine litter from the hay loft in some open but protected place. Many of our native Sparrows can be attracted in this way. Chaff, mixed with grain, and scattered in a sheltered place near the haunts of Quail may be the means of saving many from death by starvation or freezing. When hard pressed by hunger, Quail sometimes feed about hay stacks in the field or come to the barnyard where, if not molested, and a little grain is thrown to them, they will remain throughout the winter. 
During mild periods, the free lunch counter may not be visited with the same regularity as during inclement weather. At these times, the birds are busy cleaning up the dormant insect life which lies hidden away in crevices between or under the bark, among the fallen leaves, and in various other places. Should these insects escape the birds, insect control would be much more difficult. This winter "cleanup" of insect life is a "stitch in time" and the encouragement and protection given these feathered friends is well paid back in beneficial service.

PLANTING OF TREES, SHRUBS, ETC., WHICH WILL AFFORD BERRIES, NUTS, ETC., AS FOOD FOR THE SUCCESSIVE SEASONS

The planting of berry-or of nut-producing shrubs or trees is one of the ways of providing a food supply for the birds. By choosing varieties that fruit at different periods, a succession may be had lasting the greater part of the year. There are many native varieties of plants, the fruit of which is eaten by birds, but the following are a few of the best: red cedar, any of the sumacs, wild cherries, service berries, bush honeysuckle, high bush cranberries and other Viburnums, elderberries, the various dogwoods, blueberries, huckleberries, winter berry, barberry, wild grapes, Virginia creeper, mulberry and pokeweed. Some of these plants, when found growing, should be allowed to stand; many of them are among the best of ornamental plants for the home grounds. Moreover, when used in this capacity, they add greatly to the beauty of the landscape aside from the protection and food they furnish to the birds.

\section{PLANTING OF SHELTER BELTS FOR WINTER}

The value of groups of trees, especially evergreens, in breaking the force of the wind can scarcely be overestimated. Within recent years, such plantings have become fairly common, particularly with fruit growers. Wherever shelter belts or wind-breaks occur, birds are quick to take advantage of the protection thus afforded them from the elements. An evergreen screen furnishes greater protection in winter than one of deciduous trees, and many birds find snug roosting places among their amply clothed branches. Such a planting should be made on the west and northwest sides of the grounds, the direction from which come the prevailing winter winds. These trees should be allowed to retain their lower branches as well as be encouraged to make a dense growth.

\section{NESTING BOXES AND DEVICES}

To balance the conditions resulting from cleaning up of fence rows, underbrush and orchards, which deprive the birds of suitable nesting sites, everything that is possible should be done in 
the way of encouraging the birds to nest. Such species as the Woodpeckers, Chickadees and Bluebirds, that have been deprived of their natural nesting sites by the pruning away of dead branches and filling of cavities, can be induced to build in boxes constructed and erected for that purpose. If properly placed out of reach of cats, artificial nesting boxes are usually inhabited. For birds not nesting in colonies, boxes of one compartment should be made. Boxes of this type should be built for Bluebirds, Chickadees and Wrens. Weathered boards and rustic or bark-covered houses, are better liked than new or painted surfaces. Chickadees prefer a box without a perch. Bluebirds like a perch upon which to alight before entering and Wrens are not particular, but will nest in anything from an old tomato can to the most carefully constructed wren-box. If metal is used, it should be placed in the shade and bright surfaces should be avoided. Purple Martins nest in colonies, but little or no preference is shown as to the choice of the structure chosen. It may be of the plainest type or an elaborate structure, in imitation of a cathedral or castle.

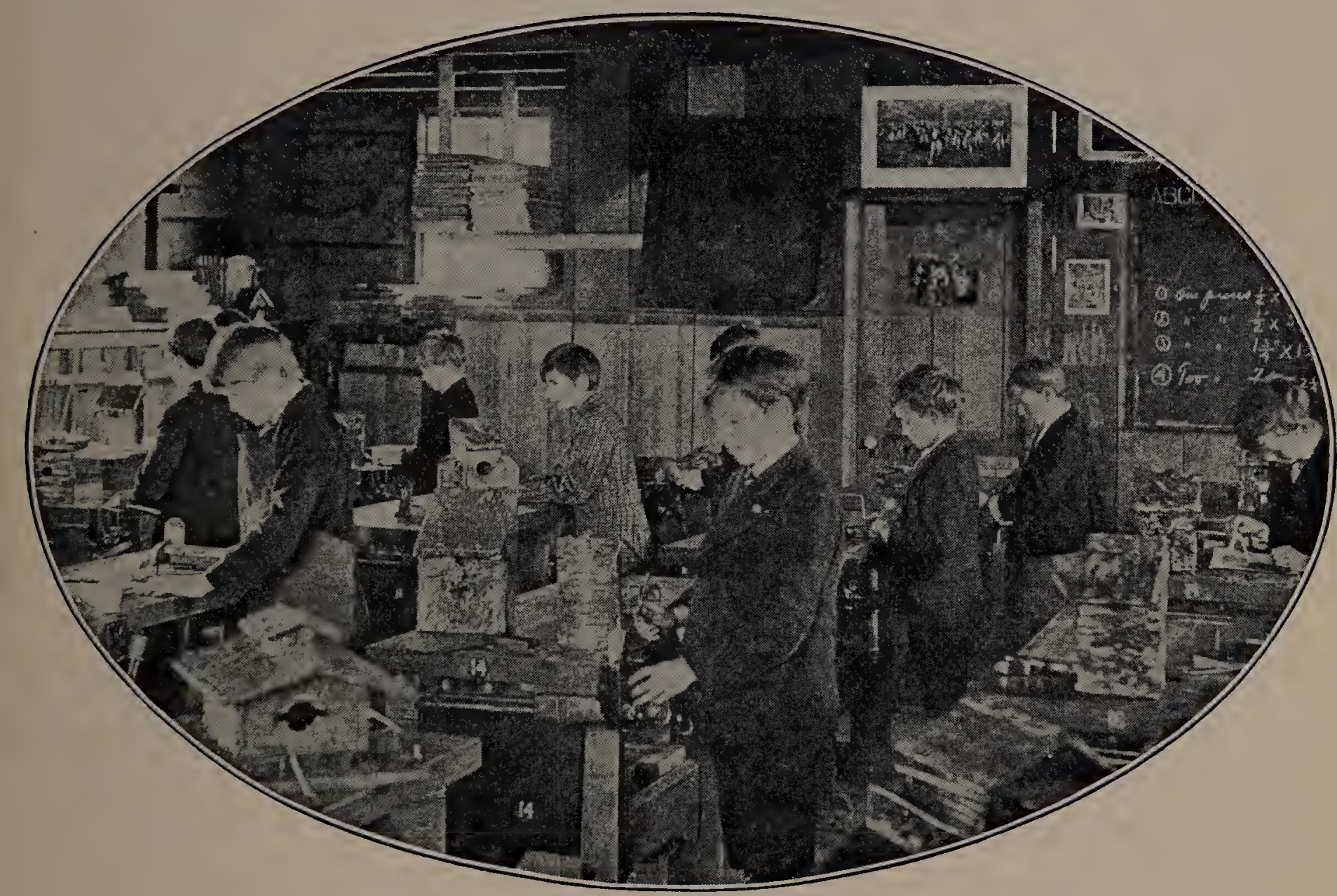

MAKING BIRD HOMES

Fig. 1. Manual Training Department of a public school, Portland, Oregon. Photo by H. T. Bohlman and used in Bird Lore Vol. 10, No. 3, p. 135.

Houses of several compartments, erected upon poles firmly planted in the ground and from fifteen to twenty feet high, are best for this species. Martins are better able to protect themselves against Sparrows if a strong colony is establisbed, as the Sparrows 
are persistent in their efforts to appropriate these houses. As a protection from cats and squirrels, encircle the pole at a height of three or four feet from the ground with a strip of tin about two feet in width. Woodpeckers can be induced to build in structures made from sections of branches in imitation of their own excavated cavities. They should be made exact in every particular, especially as to the size of the entrance. The section should be sawed lengthwise through the middle and after the cavity has been worked out, the two halves should be fastened together again.

Bird-lore has printed many articles on the building of nesting boxes. The following numbers contain a few of the best: Vol. 10, No. 3 (1908); Vol. 11, No. 2, (1909); Vol. 12, Nos. 3, 5 and 6 (1910); and Vol. 13, No. 2 (1911).

'The greatest stimulus that can be given to bird protection is through the proper training of the school children. The true value of birds, impressed upon the minds and hearts of the young, will accomplish more than legislation.

\section{DRINKING FOUNTAINS AND BATHS}

Water is a necessity, especially in summer, and if running water is not easily obtained, a bath or drinking fountain should be erected in a quiet, shaded place, protected against cats. A rusty basin in which a flat stone is placed, leaving one edge against the side and the other resting on the bottom, so that the depth of the water will vary from one-half to not more than two inches, makes a very satisfactory bath. If running water can be had, it is better, as it insures a constant and fresh supply. Where this is not possible, the water should be changed once a day.

\section{PROTECTION FROM ENEMIES}

The numerous enemies of birds keep them ever on their guard, and in spite of their vigilance, they usually come to a tragic end. Of our four-footed animals, the cat is the arch enemy of birds. Mr. John Burroughs says that cats probably destroy more birds than all other animals combined. More young chickens are killed by cats than by hawks and wild mammals. Birds and poultry are preferred to rats and mice, and once the habit is acquired, death alone will break it. Many farms harbor half-wild, self-supporting cats that live largely upon birds and poultry. Prof. E. H. Forbush has estimated that the average cat, in Massachusetts, will kill ten useful birds per year and that each farm supports a cat. Upon the same basis, Ohio's rural cat census is 276,719 . Allowing each cat its quota of ten, 2,767,190 birds are sacrificed annually; a large number, but an estimate easily within the bounds of belief, for this does not take 
into consideration the thousands of cats in towns and cities. Twoinch mesh poultry wire can be used to exclude animals or larger birds, and at the same time this will allow smaller desirable inhabitants to pass through to a food-supply or bath on the inside.

The House Sparrow has become such a nuisance and so universal in its distribution, that it is not probable it can ever be exterminated. Native birds have suffered a decrease in numbers through persecution by this introduced species. Nesting sites are wrested from our more useful and desirable native species, or their eggs and young destroyed. When the food shelf is put up and the feast spread, this nuisance among birds is the first to visit it. Though bold, this Sparrow is suspicious and does not like a shelf that moves, or a nestbox that is suspended. A shelf, hinged to the. window sill at one side and supported on the other by a weak spring, or a swinging shelf, is an improvement over a stationary one. In the country, vigorous use of the shotgun and the destruction of nests and eggs will help to hold th.m in check.*

As a protection from Hawks, shrubbery and loosely built brush piles into which small birds can take refuge, will serve the purpose.

Nests frequently become infested with vermin, especially about the habitations of man. Sometimes the parent birds are forced to abandon the young on this account. Where such conditions exist, dusting with insect powder will kill the vermin without any injury to the nestlings.

\section{BIRD LEGISLATION}

The first laws passed were for the protection of game birds exclusively, but these constitute less than a twentieth of all our birds. Insectivorous and song birds; plume, sea, and raptorial birds; all of greater or lesser economic value, received no protection until within comparatively recent years. Our revised laws for non-game birds read as follows:

\section{CATCHING AND KILLING BIRDS OTHER THAN GAME BIRDS}

Code of Ohio, Sec. 1409. No person shall catch, kill, injure, pursue, or have in his possession either dead or alive, or purchase, expose for sale, transport or ship to a point within or without the state, a turtle or mourning dove, sparrow, nuthatch, warbler, flicker, vireo, wren, American robin, catbird, tanager, bobolink, blue jay, oriole, grosbeck, (grosbeak), or redbird, creeper, redstart, waxwing, woodpecker, humming bird, killdeer, swallow, bluebird, blackbird, meadowlark, bunting, starling, redwing, purple martin, brown thresher, (thrasher), American goldfinch, chewink or ground robin, pewee or phoebe bird, chickadee, fly catcher, gnat catcher, mouse-hawk, whippoor-will, snowbird, titmouse, gull, eagle, buzzard, or any wild bird other than a game bird. No part of the plumage, skin, or body of such birds shall be sold or had in possession for sale. (99 V. 369 Sec. 22.).

*For further particulars see Farmers Bulletin 282, U. S. D. A., on "How to Destroy English Sparrows." 


\section{DISTURBING OR DESTROYING NESTS OF SUCH BIRDS}

Code of Ohio, Sec. 1410. No person shall disturb or destroy the eggs, nests, or young of a bird named in the preceding section; but nothing in this or the preceding section shall prohibit the killing of the chicken hawk, blue hawk, Cooper hawk, sharp-skinned (shinned) hawk, crow, great-horned ow1, or English sparrow or the destroying of their nests, or prohibit the owner, or duly authorized agent of the premises, from killing blackbirds at any time except on Sunday, when they are found to be a nuisance or are injuring grain or other property. (99 V. 369 Sec. 23.).

\section{PERMIT TO COLLECT EGGS FOR SCIENTIFIC PURPOSES}

Sec. 1411. The preceeding two sections shall not apply to a duly accredited person, having a permit issued by order of the commissioners of fish and game, authorizing him to collect birds, their nests, and eggs for scientific purposes only. The applicant for a permit shall present to the commissioners the written testimonials of two well known scientific persons or teachers of science, certifying to the good character and fitness of the applicant and pay the commissioner a fee of five dollars. He shall also give a bond to the state in the sum of one hundred dollars with two or more sureties approved by the commissioners that he will not kill a bird or take the nests or eggs of a bird for any other purpose than that provided herein, which bond shall be kept in the office of the commisioners. Each permit shall be in force for one year from the date of its issue and sha11 not be transferable, but upon the forfeiture of a bond of a person, his permit shall become void. (99 V. 369 Sec. 24.).

Many of our birds are more or less migratory. Some, like the seed-eaters, move only a little farther south in winter; but the majority of insectivorous birds winter beyond the borders of our country, in Mexico, the West Indies, Central and South America. Therefore, local or state laws afford but partial protection to many species. It is a national or international question. A national bill carefully drafted and wisely amended to fit local conditions, where such is necessary, would be much more effective than the present plan of disconnected state legislation. Because of changed conditions, or unwise legislation, through misconstrued information or mistaken ideas, our laws, as they stand, are not entirely satisfactory to agricultural interests, and until a national bill can be drafted, based upon our more perfect knowledge of the food habits of birds, our present laws should be revised to meet our present needs.

Among the most beneficial of our Hawks are the Red-tailed and Red-shouldered, yet these are the species commonly called the "Hen" or "Chicken" Hawk and are not protected by law. The Cooper's and Sharp-shinned Hawks are the most destructive to poultry and more deserve the appelation of "Chicken Hawk."

It cannot be impressed too strongly upon the minds of legislators that the Bob-white or Quail and the Carolina or Mourning Dove are birds of too great value to the farmer to be lawfully shot as game. Both birds are much less numerous than formerly and the Bob-white, especially, is in danger of extermination. 
The shooting of all water fowl should be discouraged during the spring migration, so as to encourage nesting again of many species that formerly nested in the state.

\section{AUDUBON SOCIETIES}

Through organized effort, much has been accomplished in way of bird protection. Chief among the many organizations of this kind is the National Association of Audubon Societies, made up of State Societies which, in turn, are composed of local chapters. The state and local organizations retain their individuality. The work is directed along the lines of education and legislation; the former being the more important, although much has been accomplished by the passage of wise laws. A number of islands along the Atlantic, Gulf, and Pacific Coasts have been set aside by the National Government as reservations for the sea birds, that they may nest and rear their young, unmolested. Wardens are maintained upon these reserves to keep plume hunters and poachers from plying their nefarious business; this has prevented the extermination of several species, much hunted for their plumes and prized for millinery purposes. Because of legislation and the activity of wardens in enforcing the laws prohibiting the sale, possessing or wearing the plumage of our wild birds, this custom has lost much of its popularity. All matters relating to birds, with a view to stimulating interest in their study and protection, are reported through Bird-Lore, ${ }^{*}$ the official organ of the Audubon Societies.

\section{ECONOMIC TREATMENT OF GROUPS AND SPECIES}

\section{THE THRUSH FAMILY}

In the classification of birds, the Thrushes have been accorded first place. As songsters, they take high rank; their voices being wonderfully sweet and expressive. They are wood-inhabiting, for the most part, and migratory. During migrations, they are more or less gregarious, when they frequent gardens and fields, as well as the woodlands, in flocks. The group is represented in Ohio by five species of true Thrushes and two closely allied species-the Robin and Bluebird. The true Thrushes occur only in summer or during the migrations; the Robin and the Bluebird are also summer residents, but are of more or less frequent occurrence in all sections of the state during winter. The food of the Thrushes and their allies is very similar, and is largely insectivorous, consisting for the most part, of injurious forms. The greater portion of fruit eaten is of wild varieties and agreeable only to the birds.

*Published bi-monthly oy D. Appleton Co., at Harrisburg, Pa. One dollar per year 
BLUEBIRD, Sialia sialis sialıs (Linn.)

Because of the association between the Bluebird and springtime, it is one of the best known of our birds. In spring, its cheery warble is in harmony with the season and its plaintive notes in the fall suggest the dying year. It is essentially a summer bird, though large numbers winter in the extreme southern part of the state and small numbers in all parts. It is a lover of the open fields and sunshine, and is esteemed by country-folk, in general, more than any other bird. Two or three broods are reared in a natural cavity, in a tree, post, or rail, or in a box provided for the purpose.

Of its food, 76 percent consists of insects and other small animal forms; 24 percent is of vegetable substances, taken mostly in winter. Of the whole food, beetles constitute 28 percent, grasshoppers 22 percent and caterpillars 11 percent. Its only offense is the eating of a few predaceous or beneficial beetles, amounting to 8 percent of its food for the entire year. The Bluebird is harmless as far as vegetable food is concerned, as this consists of wild fruits and seeds taken when insects are difficult to obtain.

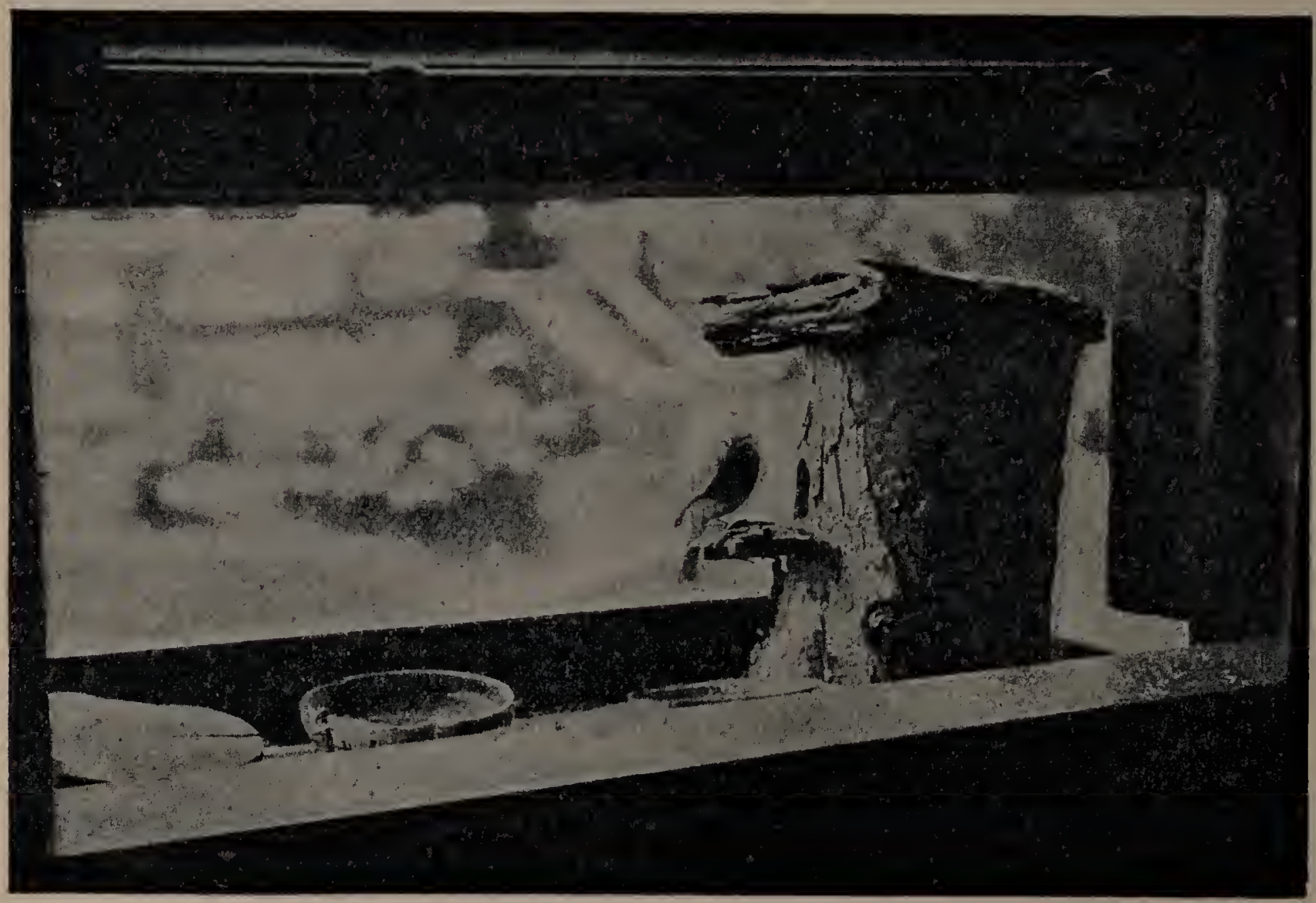

BLUEBIRD AT NEST

Fig. 2. From Bird Lore, Vol. 9, No. 1. Photo by A. P. Morse. 
The following is a partial list of berries eaten: blackberries, pokeberries, partridge berries, juniper berries; also the fruit of the bitter-sweet, of green briar, of Virginia creeper, of strawberry bush, and of the sumacs; of seeds, it consumes those of sorrel, ragweed and various grasses. By way of encouragement during the breeding season, nesting boxes should be provided. Planting shrubs which retain their fruit through cold weather may be the means of inducing many Bluebirds to winter over nearby. Protection should be given them at all times.

ROBIN, Planesticus migratorius migratorius (Linn.)

Long association with the abode of man has won for the Robin wide acquaintance, both in rural communities and in towns and cities. At one time a forest dweller, it has gradually adapted its manner of living to changed conditions, incident to the settling of the country, until, at present, few are found nesting far from the haunts of man. When not molested, little fear is shown of man. The Robin is a ground feeder, being especially partial to lawns and gardens. Little preference is shown in the selection of a nesting site and nests are frequently found in the most unlooked for places.

At the approach of fall this species becomes gregarious, deserting its summer haunts for the open woodland, where in large numbers, it forages for wild fruits and insects.

The food varies with the season; the most easily obtained is usually taken. More than one-third of the entire food consists of injurious insects; 47 , percent of wild fruit; 4 percent of cultivated fruit which is taken principally during June and July, when the wild fruit is scarce. Wild fruit is eaten every month of the year, and is the most important food for half of the year. The Robin is one of the most important enemies of the white grub, besides which, cutworms, wireworms, various caterpillars (both woolly and smooth), various beetles and many other insects injurious to crops are eaten in varying proportions. Wild fruits seem to be preferred before cultivated; but of the cultivated kinds, the small sorts suffer most, and the man having but a few cherry trees or a small patch of strawberries, loses most heavily. The planting of wild fruits around the orchard, especially those which fruit at the time when cultivated small fruits ripen, will save much of the cultivated crop, which would otherwise be lost. All wild fruits are eaten by the Robin, but a few favorites are wild cherries, wild grapes, the fruits of the sour gum, green briar, sumac, poison ivy, elderberries, huckleberries, June berries and mulberries.

Formerly, millions of Robins were shot in the South by market hunters, during their winter sojourn, and even yet the practice is carried on in states where laws are lax or where none exist. 


\section{TRUE THRUSHES}

Of the true Thrushes, the Wood, Wilson's, Gray-cheeked, Olivebacked and Hermit are found in the state. Their similar habits and brown-toned backs make these a confusing group to the beginner. The under parts of all are marked with spots of varying sizes and shapes, the latter varying from round to wedge-shaped. These markings aid materially in differentiating the species.

WOOD THRUSH, Hylocichla mustelina (Gmel.)

The Wood Thrush is a common summer resident, and the sweetest singer of our resident birds. The clear, liquid notes heard in the quiet of the sunset hour which marks the close of a summer's day are like a benediction; there is no sweeter sound in nature. The large, round, black spots on the breast and sides of this species will serve to distinguish it from other Thrushes. It loves the moist woodland, but sometimes nests in gardens and along frequented roads. The food consists very largely of ground-inhabiting insects. Some wild fruits are also eaten, but no cultivated fruits.

WILSON'S THRUSH, Hylocichla fuscescens fuscescens (Steph.)

The Wilson's Thrush or Veery is a regular but rare summer resident in the northern tier of counties, but as a migrant is quite common throughout the state.

\section{THE REMAINING THRUSHES}

The Hermit, Gray-cheeked and Olive-backed Thrushes occur as migrants, both in spring and fall. The Hermit is the commonest of the migrant Thrushes. It is first to arrive in spring, and lingers longest in autumn. It is usually found alone, and is of a retiring disposition, seldom being seen outside of woodland thickets; otherwise, the habits of the Thrushes are much the same. Insects found on the ground among the leaves, comprise the larger part of their food.

CATBIRD, Dumetella carolinensis (Linn.)

The Catbird is known in name to many persons who have no acquaintance with it through observation. Its favorite haunt is the seclusion of some low, moist, vine-tangled thicket. One might readily overlook this modestly dressed bird in its suit of dark gray with cap of black, but for its note of displeasure, much like the meow of a kitten, when its privacy is intruded upon. The sexes are not to be distinguished by their plumage.

As a songster, this bird holds high rank and its power of mimicry has won for it the name of Northern Mockingbird.

It seeks the seclusion of shrubbery when singing, being more frequently heard than seen, so that it is not strange that few people know the connection between the singer and its beautiful songs. 
Though strongly attached to the seclusion of its natural haunts, this species not infrequently comes into towns, where in the shrubbery of gardens and lawns, it nests, rears its young and sings. Its activity in destroying injurious insects makes its presence in the garden desirable.

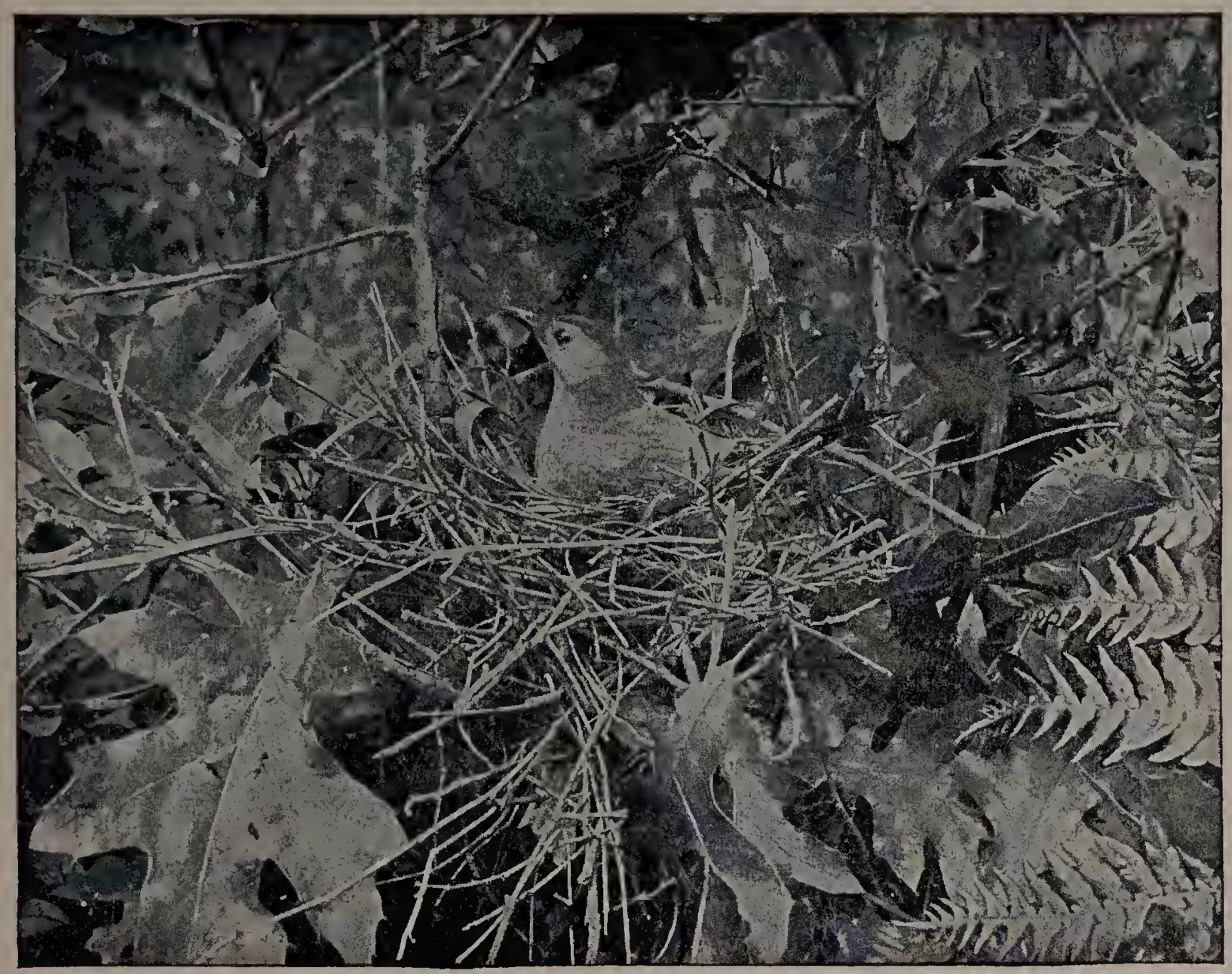

CATBIRD ON NEST

Fig. 3. From Bird Lore, Vol. 13, No. 3.

The food is 44 percent insect, of which ants, beetles, caterpillars and grasshoppers constitute three-fourths. Of the 56 percent vegetable food taken, one-fourth is of cultivated fruits, or those that may be cultivated; such as strawberries, raspberries and blackberries. Since these berries are commonly found growing wild, it is probable that but little damage is done to cultivated crops. The fruits of many native shrubs and trees are eaten; cherries, dogwood, sour gum, green briar, elderberries, spice berries, black alder, sumac and poison ivy being the most important.

\section{SOME WINTER BIRDS THE KINGLETS}

With the approach of winter, the close observer will notice many very small birds flitting about the tips of the branches of forest, orchard or shade trees. They are constantly in motion; as they hop along the branches in search of food they flit their wings in a nervous, characteristic manner. They are the Kinglets. Their food 
consists of plant lice, scale insects, insect eggs and other small insects, some of which are very minute. Two species occur throughout the state during migrations; their habits and dress are much the same.

GOLDEN-CROWNED KINGLET, Regulus satrapa satrapa (Licht.)

This species is not common as a winter resident, but is much more common as a migrant, both in spring and fall. It is a little smaller than its Ruby-crowned cousin, and next to the Hummingbird, is our smallest bird. The call note is high pitched and audible only to the practiced ear. The voice is of unusual volume when singing, yet not at all conspicuous. The summer home of both species is in the forests of spruce, fir and pine, and while with us, they show a decided liking for evergreens.

RUBY-CROWNED KINGLET, Regulus calendula calendula (Linn.)

This species occurs only as a migrant. It is to be distinguished from the preceding species by its slightly larger size, wren-like call note, and by the conspicuous gold of the crest being replaced by a partly concealed red spot; also the song of this species is louder and sweeter than that of the Golden-crowned.

\section{THE NUTHATCHES, CHICKADEES, CREEPERS AND WRENS}

The Nuthatches, Chickadees, Creepers and Wrens all subsist largely on insects; the habits of these birds, their manner of hunting and the kind of insects destroyed differ widely.

WHITE-BREASTED NUTHATCH, Sitta carolinensis carolinensts (Lath.)

This bird is a common resident throughout the state, possibly a little more common in winter than in summer. However, it may only appear to be more abundant at this time because of its more frequent occurrence in parks, on street shade trees, or about the home grounds. As a climber, this species has no equal. With ease and grace it runs over the bark of trees, up, around, or rests head downward. The strong feet and legs alone are depended on for support.

The food is largely insects, their larvae and eggs, which are hidden away in crevices of the bark, many of which would escape a less nimble climber. The vegetable portion of its food consists chiefly of beech nuts and acorns, which it hides away in crevices of bark until needed. The name "nuthatch" is derived from the manner in which it breaks open an acorn or nut, by striking it forcibly with the bill, thus "hatching it" after having wedged it in a crevice. It is wrongly called "sapsucker" and the prejudice which many hold against it is due to the supposed injury it does to the bark of trees. 
Neither this species nor the rarer Red-breasted Nuthatch is harmful in any way, but, on the other hand, they are of great economic benefit.

RED-BREASTED NUTHATCH, Sitta canadensis (Linn.)

This species is slightly smaller than the preceding and has a black line through its eye and a rusty breast and belly in place of pure white. The two species associate together and their food and habits are much the same. It occurs only as a rare winter resident, or during the migration, and is at no time common.

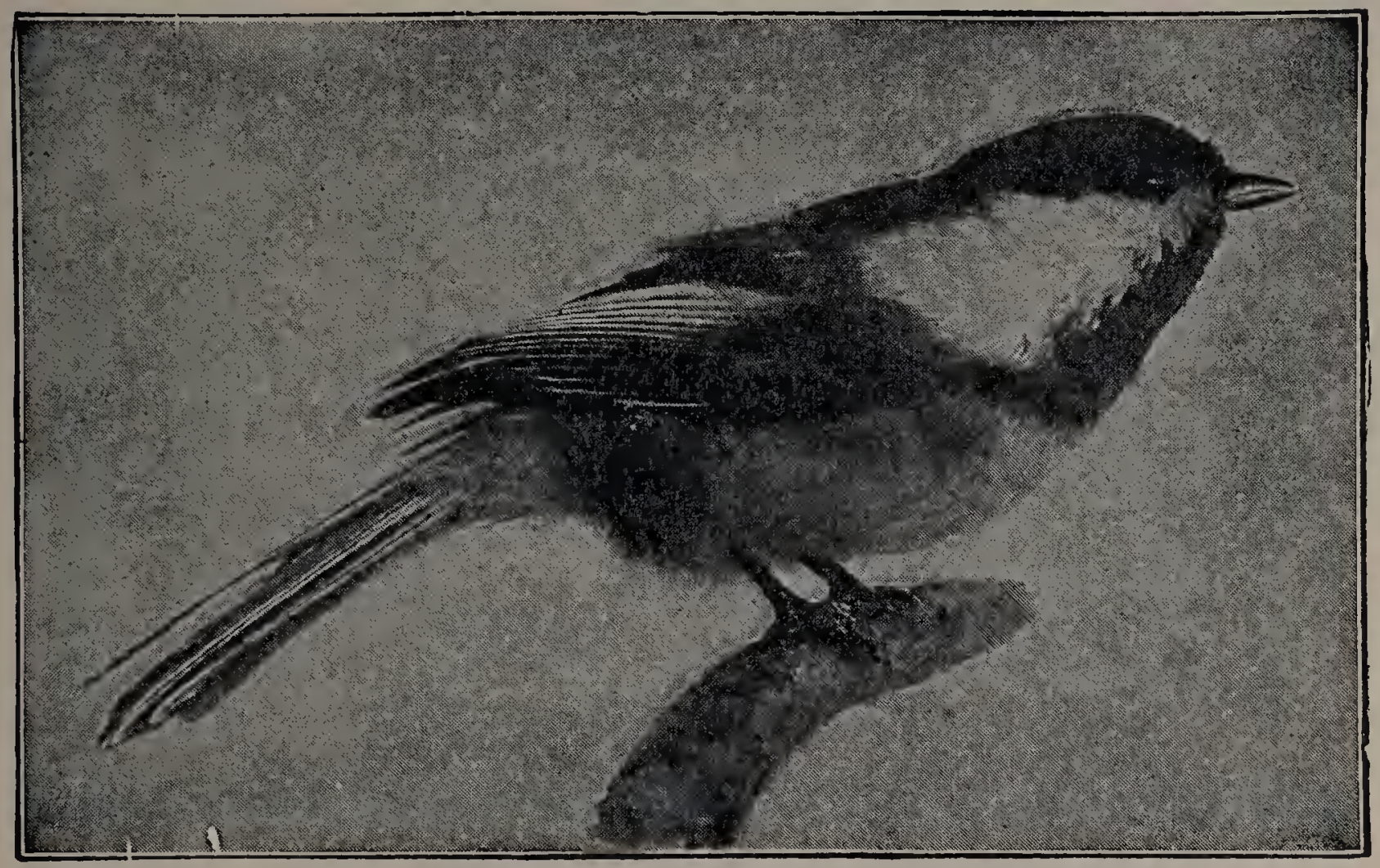

THE BLACK-CAPPED CHICKADEE Penthestes atricapillus atricapillus

Fig. 4. After Washburn, Ninth Annual Report, State Entomologist of Minnesota.

CHICKADEE, Penthestes atricapillus atricapillus (Linn.)

Throughout the state, the year round, this species is a common bird, and is generally designated as the Black-capped Chickadee.* In summer, it is seldom seen except in the forest where it nests in cavities; but in the winter, it is attracted to the trees of the orchard, lawn, or city street, where it is apparently as much at home as in the depths of the forest. It is gentle in disposition, confiding and cheery, and courageous in defense of its young. When the tide of bird life is at lowest ebb, this hardy little bird braves the rigors of the winter, seeming to suffer no discomfiture, and keeps up a diligent search for dormant forms of insect life, upon which it chiefly subsists at this season. It is a most valuable species.

* In addition to this form, the Carolina Chickadee, $P$ 。 carolinensis carolinensis, is found in the southern half of the state. The two are very similar in appearance and habits. 
It is of especial economic value to the fruit grower. Its entire food is composed of insects, when obtainable, but in times of scarcity of such food, seeds and berries are eaten. Tent caterpillars, canker worms, codling moths, bark beetles and plant lice, in all their stages, are eaten. It is especially noted as a destroyer of the canker worm moths, larvae and eggs.

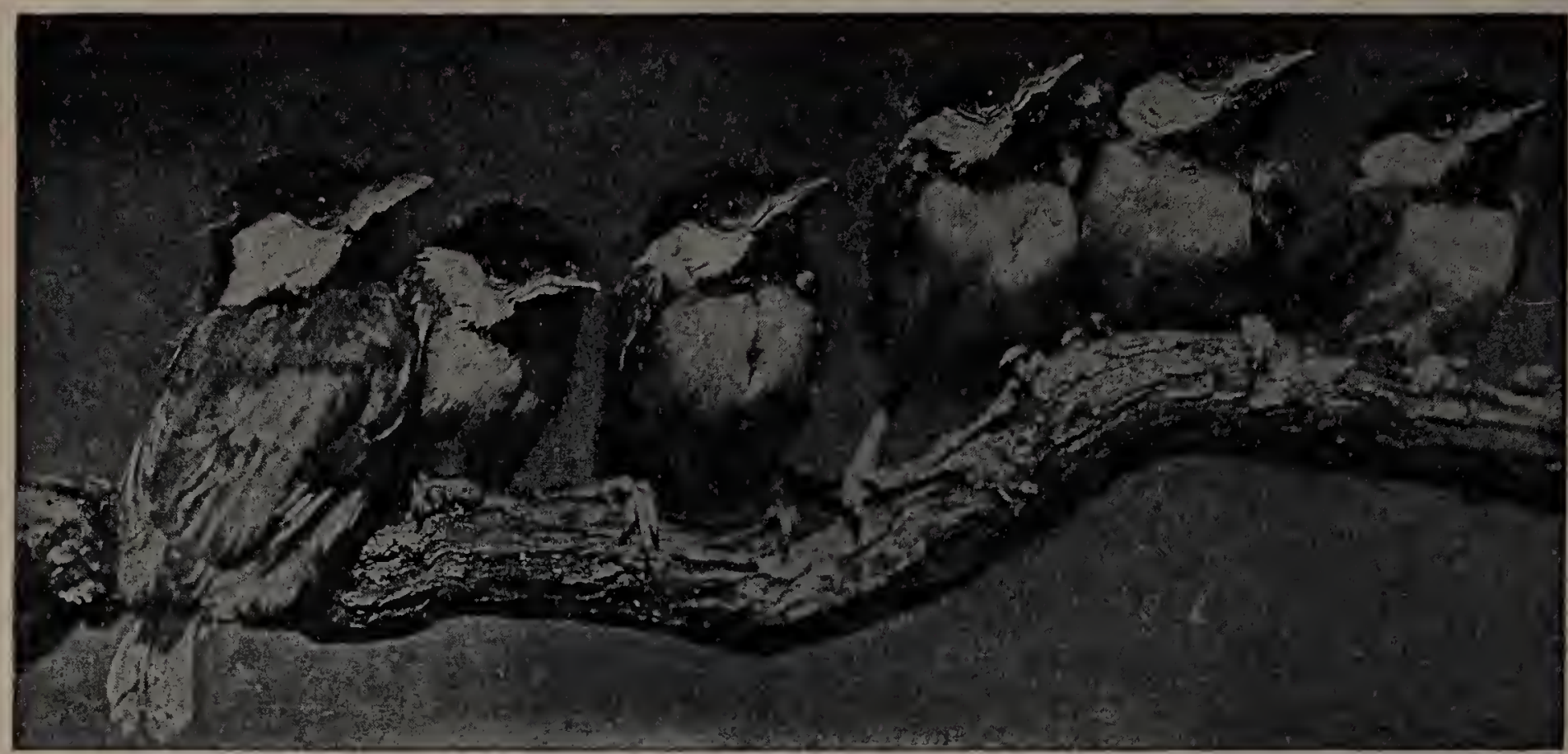

YOUNG CHICKADEES

Fig. 5. "They know whence comes their mothers call." From Bird Lore, Vol. II, No. 2. Photo by Mary C. Dickerson.

BROWN CREEPER, Certhis familiaris americana (Bonap.)

This unobtrusive, weak-voiced bird is readily overlooked by the average person. It most commonly frequents woodlands, more rarely park or shade trees, where it gleans a living from the insect life that lies hidden in the crevices of the bark. A bird of fixed habits and its daily life one of the strictest routine, it pursues its task with tireless persistence. Beginning near the base of the tree, it winds its spiral way up the trunk and larger branches, scrutinizing the crevices for any insect life that may be hidden there. When the smaller branches are reached, it drops to the base of a nearby tree to repeat, in the same manner, its endless task of insect destruction.

\section{WRENS}

The Wrens, near relatives of the Catbird and the Thrashers, ar. small birds, modestly dressed in brown tones, and indistinct $t_{s} y$ streaked. Their tails are short and erect, or inclined forward, giving them a pert, bantam-like appearance. They are bold, aggressive, and of a prying, inquisitive and nervous disposition. I heir voices are loud, and their notes varied; songsters, they are, of no mean ability. Their food is made up almost wholly of insects, 
largely picked up on or near the ground. Ground beetles and grasshoppers compose 50 percent of their whole fare; caterpillars and spiders a large part of the balance. Their hunting is done in the vicinity of the nest, as they are weak fliers. Thus, they are of especial value wherever they nest. Six species are found in the state, only two being of common and general distribution and which are, therefore, of much economic importance.

CAROLINA WREN, Thryothorus hudovicianus hudovicuanus (Lath.)

This Wren is found in winter and summer alike. Unlike the House Wren, with which this species is frequently confused, its favorite haunt is the tangle of the forest. Its loud, rollicking song may be heard in winter as well as in summer. The trespasser on this bird's domain is informed of the owner's presence by a series of chattering, scolding notes, issuing from the depths of a brush pile. From this safe retreat, every move of the intruder is watched.

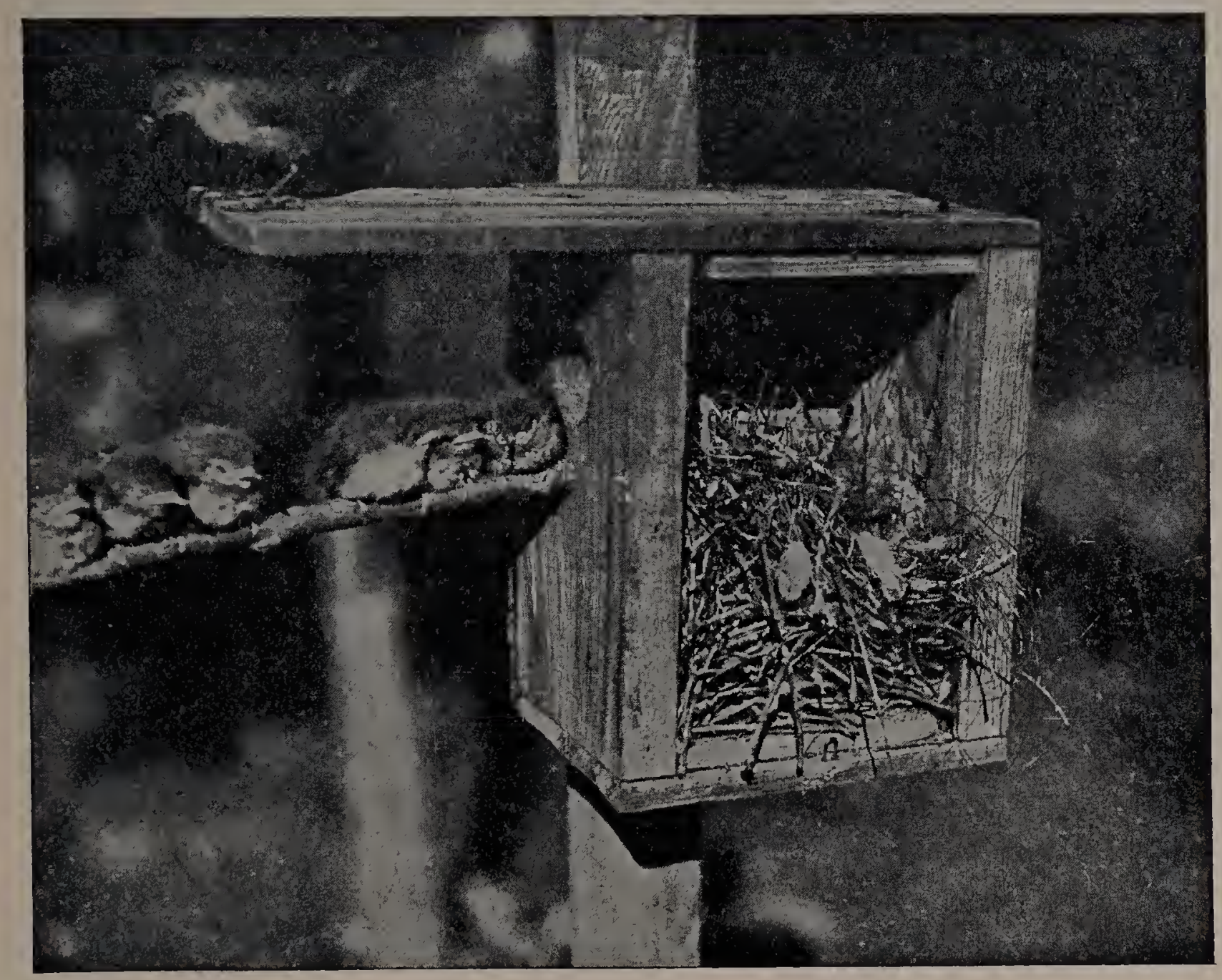

HOUSE WREN AT NEST

Fig. 6. From Bird Lore, Vol. 9, No. 5. Photo by F. L. Holts.

This is the largest of the Wrens and can be distinguished from the House Wren by a conspicuous whitish line over the eye, as well as by its larger size. 
HOUSE WREN, Troglodytes aêdon aedon (Vieil.)

This common bird of the garden is of general distribution in settled communities over the state, but is being replaced to some extent, in the southern part, by the Bewick's Wren. When it nests away from the habitations of man, it is not by choice, but because of conditions.

A pair of Wrens is a valuable asset to the garden. During the nesting season, when two broods, sometimes three, are reared, the song of the male is conspicuous. The persistence with which food is sought to feed the growing young, results in the destruction of great numbers of insect enemies of crops, particularly those affecting the vegetables. Boxes should be placed in shaded situations and not close together, since but one pair of Wrens occupy a garden.

WARBLERS AND VIREOS

To the uninitiated, the members of the Warbler and Vireo families are more or less confusing, but with better acquaintance, the two groups separate themselves naturally. The Warblers are much more active, flitting, darting, constantly in motion, while the Vireos are more deliberate in their movements. Both groups are forest dwellers, with few exceptions, and insectivorous. Some of the Warblers are arboreal, seldom feeding below the tops of the tallest trees; others are terrestrial, walking with the ease and grace of a partridge.

During the month of May the tops of the forest trees, the undergrowth, orchard, and tangled thicket, alike throng with the migrating warbler host. The migration reaches its height about the third week, few remaining after the first of June, except those which are summer residents and remain to nest.

Great diversity of habits, plumage and song are to be found among the members of this large and interesting family. They constitute an American family, not being represented in the O1d World, and are of great economic importance in protecting the forests from insect devastation. Longfellow calls them

"Best gems of Nature's cabinet,

With dews of tropic morning wet."

BLACK AND WHITE WARBLER, Miniotilta varia (Linn.)

This Warbler is also known as the Black and White Creeper, which term describes the color and habit of the bird. It is a rare summer resident, of local distribution, found only in woodlands; but during the migration it is common and may be found in parks, orchards or on shade trees of towns. Its manner of feeding is identical with that of the Nuthatch. The song of this species is 
monotonous, weak, and inconspicuous among the many spring songs. It is among the first of the Warblers to reach the state in the spring, and may be looked for late in April or in early May.

YELLOW WARBLER, Dendroica aestiva aestiva (Gmel.)

This species is the commonest and most sociable of the Warblers. It reaches the state with the advanced guard of the warbler host, by the third week of April. It frequents alike orchards, gardens, and shrubbery of lawns, or the wild tangle of swampland. Its. simple, pleasing strain is one of the familiar sounds of summer. This species is of much economic importance about the orchard and garden in controlling aphids, weevils, small caterpillars and other insect pests. It would be difficult to find a more useful species among our summer birds. Nests are frequently built in fruit or ornamental trees.

MYRTLE WARBLER, Dendroica coronata (Linn.)

This species is the commonest of the transient warblers; the earliest to arrive in spring and the last to depart in autumn. It is usually found in open country as well as woodland. Its acquaintance is easily made; the yellow patches on crown and rump are distinguishing features. The call note (tchip) is characteristic.

It received its common name because of its fondness for myrtle berries; besides these berries, it eats other berries, seeds and insects, most of which are gleaned from the ground.

OVEN-BIRD, Seiurus aurocapillus (Linn.)

The Oven-bird, also known as Golden-crowned Thrush, is a true warbler. Its favorite habitat is moist woodland, where it lives on the ground, walking about among the leaves in the soft twilight of the undergrowth, looking for such insects as are usually found in such places. Its nest is dome-shaped and is always built on the ground among the fallen leaves. Because of the resemblance of this dome-shaped nest to an old-fashioned Dutch oven, the bird is known as the Oven-bird. In the quiet and solitude of its retreat, its song bursts upon the ear with startling force. Mr. John Burroughs describes its crescendo chant thus:

"Teacher, teacher, TEACHER, TEACHER, TEACHER."

MARYLAND YELLOWTHROAT, Geothlypis trichas trachas (Linn.)

This Warbler shuns the forest, preferring the more open situations, particularly the low, bushy growths of moist ground. It is of a restless, inquisitive disposition, possessed of marked individuality. Its sharp metallic call note is uttered upon the slightest provocation, but only an occasional glimpse of the bird itself, as it slips through the tangled growth, will reward the intruder. The 
song is given with characteristic energy, in keeping with the restless nature of the bird. It varies in different localities, but wich-i-ty, wich-i-ty, wich-i-ty (the accent on the first syllable), expresses its song.

Its food consists of the various insects which infest the lowgrowing plants, among which the bird lives. Because of its destruction of large numbers of leaf hoppers, grasshoppers, canker worms and many other pests of grain and grass lands, it must be regarded as a valuable bird.

YELLOW-BREASTED CHAT, Icteria virens virens (Linn.)

This unwarbler-like Warbler is the largest of the family. Wherever it occurs, it is more frequently heard than seen. It lives among the dense tangled growth of briar patches, both of moist lowland and of the drier upland; from these safe retreats issue in confused order a series of varied sounds, the song of this interesting bird. Through its power of mimicry, one is led to believe numbers of different birds and animals inhabit the briar patch where but one Chat is singing. No bird is more suspicious or watchful, and it is seldom that one is seen on the nest. This species is much more common in the southern part of the state than elsewhere, but everywhere is of local distribution.

REDSTART, Stophaga ruticilla (Linn.)

The climax of warbler activity is attained in the Redstart. It feedsafter the manner of the flycatchers and, when darting in and out among the foliage after flying insects, the beautiful black and salmon of the male is displayed to best advantage. It occurs as a rare summer resident of local distribution over the state, but more commonly as a migrant, both in spring and fall.

RED-EYED VIREO, Vireosylvia olivacea (Linn.)

This Vireo is generally distributed throughout the state wherever there is woodland. It prefers the heavier timber with good undergrowth but not unfrequently takes up its residence in parks. The song is sweet and melodious, but the persistence with which it sings throughout the long summer days makes it monotonous. It is frequently the only bird heard singing in mid-day during the hot days of late summer. It is a very active destroyer of caterpillars and other insects, especially those forms dependent upon mimicry or protective coloration to escape notice. Few birds are more deliberate or thorough in their work of insect destruction. Although insectivorous, it appears to eat more fruit than other Vireos. The fruits eaten are native berries of no value to man. Its nest is a pensile cup, woven in the fork of a branch. It is usually placed in the undergrowth at a height of from five to ten feet. 


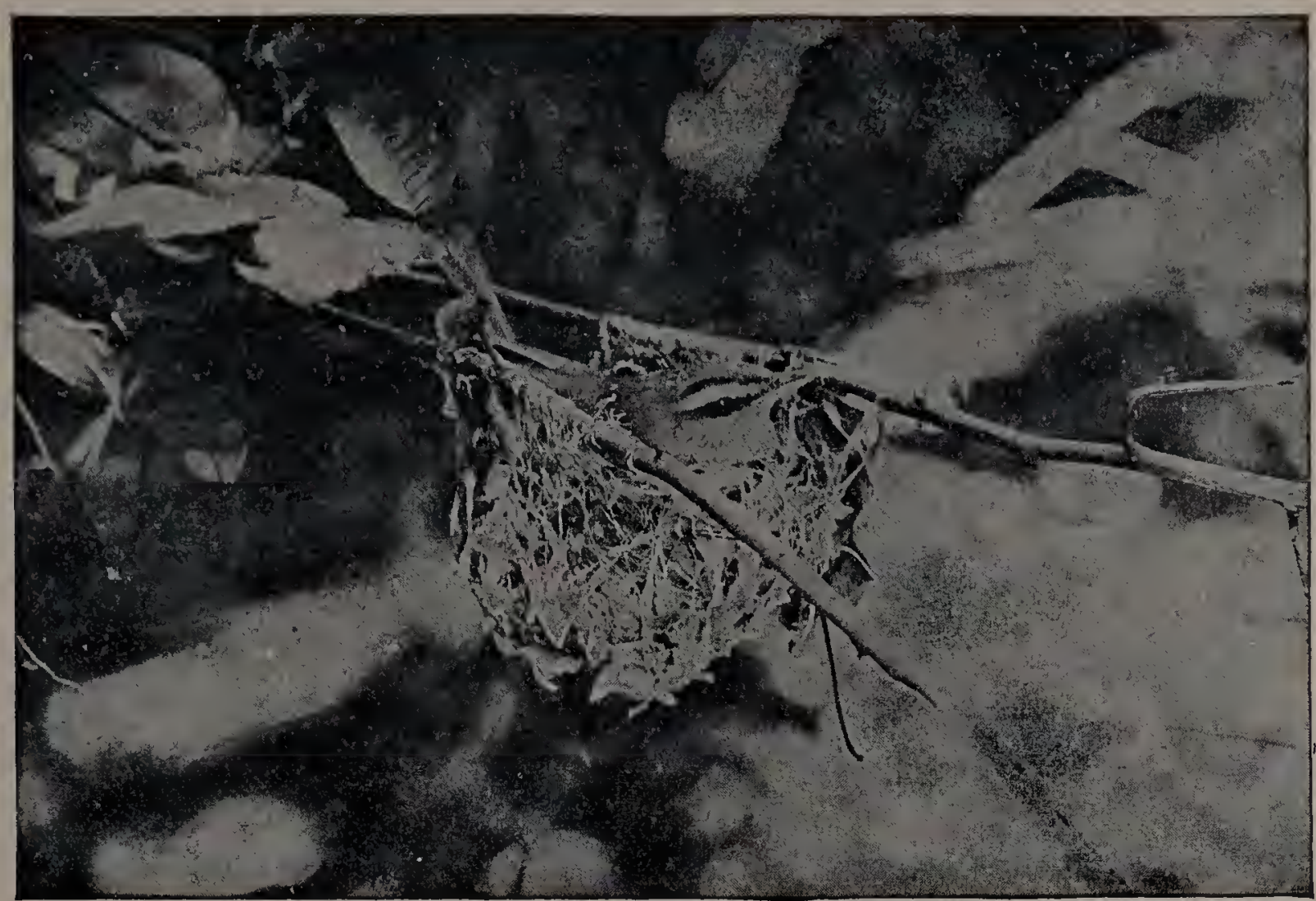

RED-EYED VIREO ON NEST

Fig. 7. From Bird Lore, Vol. II, No. 4. Photo by F. M. Chapman.

WARBLING VIREO, Vireosylva gilva gilz'a (Vieil.)

This species is common all over the state, frequenting orchards and shade trees of parks and of the city streets. Its song is more pleasing and animated than that of the preceding species and the bird is more active; departing from the usual habit of the Vireos, it sometimes takes insects on the wing like a flycatcher. It is of great service to man in destroying large numbers of injurious insects. Its food is largely caterpillars and other leaf-feeding insects, but various flies, mosquitoes, and some wild fruits are also eaten. Its nest is much like that of the preceding species, but is slightly smaller, and is commonly found in a fruit or shade tree.

YELLOW-THROATED VIREO, Lanivireo favifrons (Vieil.)

Because of the similarity existing between the songs of this and the Red-eyed Vireo, they are frequently confounded. That of the Yellow-throated Vireo is more expressive, interrogative, less monotonous, and is sung from the tops of the taller forest trees. It is the only one of our Vireos having a bright yellow throat and breast.

\section{OTHER VIREOS}

The Blue-headed Vireo occurs as a migrant and is seldom seen outside of woodland. The White-eyed Vireo is a summer resident in the southern and eastern parts of the state. 


\section{SHRIKES}

The Shrikes have been a source of considerable contention to those interested in the nomenclature of birds as well as being a source of great annoyance to those concerned with the cataloging of them. Two species and an equal number of sub-species occur in Ohio at sometime during the year.*

The food habits and general characteristics of all the Shrikes are the same. Their bills are hooked like those of the birds of prey, proclaiming their murderous natures, but their feet are weak and harmless like those of other perching birds.

\section{NORTHERN SHRIKE, Lanius borealis (Vieil.)}

This Shrike is observed only as a rare winter resident, of regular occurrence in the extreme north, more irregular southward. It is a solitary bird, except when nesting. Individuals may be found in towns as well as in field and woodland. Its food consists of birds, 35 percent, of which English Sparrows comprise 10 percent; insects, 40 percent, and mice, 25 percent.

\section{LOGGERHEAD SHRIKE, Lanius ludoucianus ludovicianus (Linn.)}

Both this and the White-rumped Shrike occur over the state in summer, the former being more common southerly. A dead branch or other elevated perch is selected as a station from which to watch for prey. Mice, birds, or the larger insects comprise the usual fare. The practice of impaling their victims on thorns or sharp twigs, a practice common to all Shrikes, has caused them to be called "Butcher-birds."

The food of this species is much the same as that of the preceding, except that more insects are eaten. Mice constitute 16 percent, birds 8 percent, insects and allied forms 72 percent of the food for the entire year. Grasshoppers and crickets are eaten in large numbers during summer. Snakes and lizards are sometimes eaten. The balance for good in case of this species, contrary to its general reputation, is decidedly in its favor; however, it should not be tolerated about the garden where small insectivorous birds will be killed or driven away by it.

\section{CEDAR WAXWING}

CEDAR WAXWING, Bombycilla cedrorum (Vieil.)

The Cedar Waxwing or Cedarbird is songless, in fact, almost voiceless, the only sound being a low, wheezy, whistled note, audible only to the practiced ear at no great distance. It is one of the most beautiful of our birds, but its unobtrusiveness not infrequently

\footnotetext{
* The A. O. U. Check-list, third (revised) edition, includes under Loggerhead Shrike (Lanius ludovicianus ludovicianus Linn.) the two sub-species (for Ohio) as follows: 'b. White-rumped Shrike (L. l. excubitorides Swains.); e. Migrant Shrike (L. l. migrans Palmer.)
} 
causes it to be overlooked. While it is one of our common birds, its occurrence is local and irregular. It is sociable to a high degree, moving about in small flocks, every movement being executed as by a common impulse. At all seasons it is more or less gregarious; when alighting in a tree, a flock never scatters, and when roosting the same is true. It never associates with other species.

Because of its fondness for cherries, it is known as the Cherrybird. Only 13 percent of cultivated fruit is eaten, and such fruits as raspberries and blackberries are taken partly from the wild bushes. However, this injury to fruit is offset by the consumption of 13 percent of animal matter, consisting of canker worms, beetles and plant lice. The remainder is made up of wild fruit and seeds. As a destroyer of canker worms alone, the Cedar Waxwing is too valuable a bird for the fruit grower to destroy. Protect the cherries by planting mulberries, which they greatly prefer, about the orchard and grounds, rather than shoot this beneficial species.

\section{SWALLOWS}

The return of the Swallows to their summer home is accomplished with almost the same regularity as is the changing of the seasons. Weather conditions, alone, can influence their movements and their arrival marks the end of winter's reign. Most aerial of our birds, this group fills an important place in nature; through their agency the air is rid of vast numbers of insects detrimental alike to the health of man and beast, as well as of some that are destructive to crops.

Their association with man had its beginning before the advent of the white man on this continent. The Indian attracted the Purple Martin by hanging up gourds in which these birds nested. When the log cabins of the white settler replaced the tepees of the red man, the Swallows nested in or about the rude log barns or in boxes erected for the purpose.

PURPLE MARTIN, Progne subis subus (Linn.)

Because of persecution by the House Sparrow, this species is gradually decreasing in numbers. Not only is it a delight to the person of aesthetic temperament, but it appeals to the most utilitarian because of its destruction of noxious insects, and the loss of this species would be sorely felt. While the great majority of Martins nest in houses erected for the purpose about dwellings, some still nest in cavities of dead trees in the wild.

The food of this species is composed entirely of insects which it takes on the wing-Rose beetles, May beetles, cucumber beetles, house and other flies, and many other equally troublesome insects. 
A quart of the wing covers and other hard parts of the striped cucumber beetle has been taken from a single compartment of a nesting box of this species. Its hatred of Hawks is very marked and its presence is desirable about the poultry yard as a safeguard against loss in this way. By erecting nesting boxes and protecting from House Sparrows, this species should become more common.

BARN SWALLOW, Hirundo erythrogastra (Bodd.)

The Barn Swallow is no longer the abundant rural resident that it once was. The modern closed barn offers it no welcome, as did the more open barns of the past, where large colonies of these birds nested. This species is pretty generally distributed over the state in summer, nesting wherever suitable sites are to be found. The House Sparrow is responsible, to a large degree, for the diminution in numbers of this species. The eggs and young of whole colonies are known to have been destroyed, in some instances, by this introduced species.

The sum total which these birds destroy of flies, mosquitoes and numberless insects detrimental to human health, as well as of those injuring fieid crops and fruit, far exceeds the comprehension of man's mind.

\section{OTHER SWALLOWS}

Other species occurring in this state as summer residents are: Cliff or Eaves Swallow, of local distribution and usually common wherever it occurs; Tree Swallow, common only at Lewiston reservoir; Bank Swallow, locally common throughout the state, and Rough-winged Swallow, also locally common throughout the state.

\section{TANAGERS}

The Tanagers comprise one of the largest families of birds. These are distinctly American, the greater number being confined to the tropics. As a family, they are noted for the brilliancy of their plumage, but they do not rank high as songsters. They are arboreal and forest inhabiting. Only one species is common throughout Ohioduring the summer, although a second species, the SummerTanager or Summer Redbird, sometimes occurs in the northern and is quite common in the southern part of the state.

SCARLET TANAGER, Piranga erythromelas (Vieil.)

This species is the most conspicuously brilliant of our summer birds. The body of the male is of flaming scarlet, which contrasts sharply with the jet black of wings and tail. It is a bird of retiring habit, keeping well up among the foliage of woodland trees, and is, therefore, not a well known bird. Its presence is made known by a characteristic chipp-churr and the song of the male is a loud, rhvthmical carol, not unlike the Robin's song. 
The beautiful olive-green plumage of the female blends perfectly with the foliage, affording her the necessary protection while attending to her duties of incubation. The loosely built nest is usually placed in the taller undergrowth or in the lower branches of larger trees, preferably along the borders of woods. At the approach of autumn, the scarlet of the male is replaced by olive-green, rendering him less conspicuous during the southward migration.

The food of this species is almost entirely insectivorous, including caterpillars, leaf-rollers, wood-boring beetles, weevils, flies and many other forms injurious to forest trees. It is especially useful for the destruction of night-flying moths and insects which depend upon protective coloration to escape their enemies. No woodland bird is more useful for the destruction of noxious insects.

\section{SPARROWS AND FINCHES}

The family to which the Sparrows and Finches belong, comprises the largest existing family of birds, both as regards number of species and of individuals. Its members are almost cosmopolitan in their distribution, being represented in every part of the world except Australia. They show wide variation in form and habit, but all possess stout bills adapted to crush seeds, which comprise their chief food. As a group the Sparrows are not so highly migratory as birds which depend more largely on insects for food. They are spread over their geographical range at all seasons except that some species retire southward from its extreme northern limit in winter.

The Sparrows are, for the most part, dwellers of the fields; their brown, streaked plumage renders them inconspicuous. All are song-birds of more or less musical ability. The brighter Finches and Grosbeaks are woodland dwellers, and are gifted singers. Many of our caged birds belong to this group.

The food of adult Sparrows consists of from 25 to 35 percent animal matter for the entire year, and of vegetable matter, 65 to 75 percent. The animal matter is chiefly insects-grasshoppers, beetles and caterpillars constituting nine-tenths of the whole a mount. The vegetable portion is composed almost entirely of seeds, but a smali quantity of fruit is taken. The young, while in the nest, are almost wholly insectivorous. Because of their general distribution on cultivated land, they are of greater value to the agriculturist than any other group of birds whose economic status has thus far been investigated. The English Sparrow, which is an introduced species, and is not included with our native birds, is very injurious. (Judd.)

The Grosbeaks and Finches differ from the Sparrows in being more brilliantly plumaged and wood-inhabiting. As a group, they 
are 'arger, hardier birds, more or less gregarious during winter and are songsters of high rank. Their rood is chiefly vegetable matter。 On the whole, they are beneficial, although a few do some damage by eating tree seeds and buds.

PURPLE FINCH, Carpodacus purpureus purpureus (Gmel.)

This sweet songster is not well enough known in the state to be recognized generally. It occurs as a migrant or rare winter resident, but is at no time common. The flight is undulating, and the metallic call note uttered when in flight is characteristic. The plumage of the male is a suffused rose-red. It is one of the sweetest songsters of this large family of gifted singers; hence, its universal popularity as a cage bird. It is noted as a bud eater, but the good resulting from its destruction of weed seeds and of insects probaibly more than balances the harm it does.

AMERICAN GOLDFINCH, Astragalinus tristis tristis (Linn.)

Known to many as Thistle-bird or Wild Canary。 It is one of our common birds of the open country, and one of unusual individuality. The musical call which accompanies the gliding, undulating flight is unmistakable in summer, and can be confused alone with that of the Redpoll which occurs as a rare and irregular winter visitor. The handsome jet and gold of the male is a delight to the eye, and the wild, sweet, canary-like melody is equally pleasing to the ear. Few birds are possessed of so many good qualities; not only is the Goldfinch a handsome bird and a sweet singer, but also it is of great im portance from an economic view point. Noother bird destroys so many seeds of thistles and other composite plants. Besides the foregoing, seeds of ragweed and of many other equally troublesome plants are eaten in quantity. This bird is fond of the seeds of the sunflower, and its presence is assured in the garden if these plants are found growing there. It is especially active in its destruction of plant lice, caterpillars and small grasshoppers, while the Hessian Fly, so injurious to cereal crops, is eaten to some extent. The nesting season is not until late summer, later than that of any other bird except the Cedar Waxwing.

VESPER SPARROW, Pooecetes gramineus gramineus (Gmel.)

Also known as Grass Finch, Bay-wing Bunting and Ground-bird. Although one of our most abundant species, it is not ordinarily distinguished from other ground-dwelling Sparrows. This bird frequents country roads, grass and grain fields. Progress is made by running (not hopping), and this together with the characteristic white outer tail feathers, so conspicuous in flight, should readily 
identify it in the field. The song is a simple strain of unusual pathos, and it is because of the bird's habit of singing at sundown that it has been named Vesper Sparrow.

The vegetable diet of this species is made up entirely of seeds, the greater proportion of which are from noxious weeds that infest cultivated land. A little grass seed and grain compose the remainder of the vegetable food. The grain is largely oats, much of which is gleaned from horse droppings, and from oat fields after the crop has been harvested. Insect food is taken in excess of vegetable matter during summer and amounts to 90 percent of the entire food at the height of the breeding season. Beetles, grasshoppers, crickets, hairless caterpillars, bugs and ants are the forms most frequently eaten. In June, 20 percent of its food is weevils, and about 10 percent click beetles. Predaceous beetles comprise only 2 percent of the year's food. This species is of great service to the farmer, feeding as it does among his crops and doing no appreciable harm.

\section{SLATE-COLORED JUNCO, Funco hyemalis (Linn.)}

This familiar bird of winter is best known as Snowbird (of the East), although it arrives in the fall, long before snow falls, and lingers until late April. It is found in weedy fields, or at the edge of woodlands, and frequents the home grounds in the rural districts or town suburbs when the snow lies deep. These birds are sometimes seen in company with the House Sparrows, especially about dwellings, but they are readily distinguishable from the latter. The slaty-gray of the upper parts, throat and breast, contrasts sharply with the white belly. The bill is flesh-colored, and the outer tail feathers are white, showing conspicuously in flight. The cheery

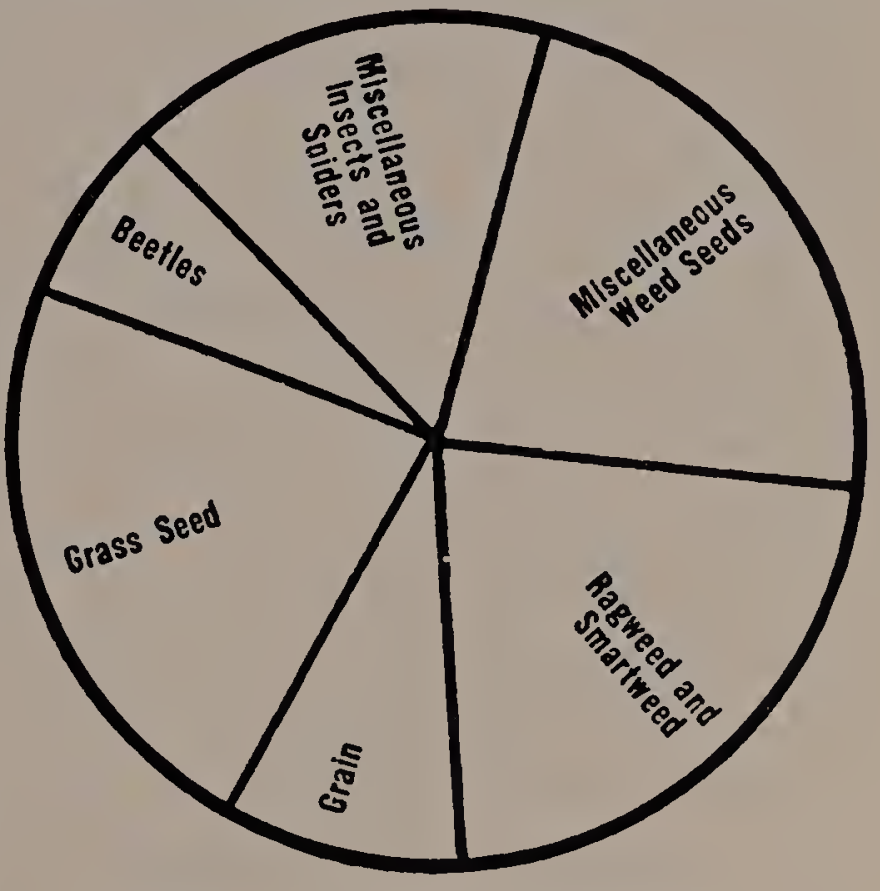

Fig. 8. Food of the Junco. twitter, heard at all times, together with the plumpness of body and the sleek plumage, suggest prosperity. Only nine percent of their food for winter is animal, the remainder being largely the seeds of noxious weeds. The comparative size of the segments in the accompanying circle graphically illustrate the relative proportions of various foodstuffs consumed.

\section{SENG SPARROW, Melospzza melodia melodia (Wilson)}

This is another of our ground-inhabiting birds, of general distribution over the entire state, abundant in summer, but much 
less so in the northern part, in winter. The preferred habitat is low, moist ground, among briars and weeds, in the vicinity of water, but

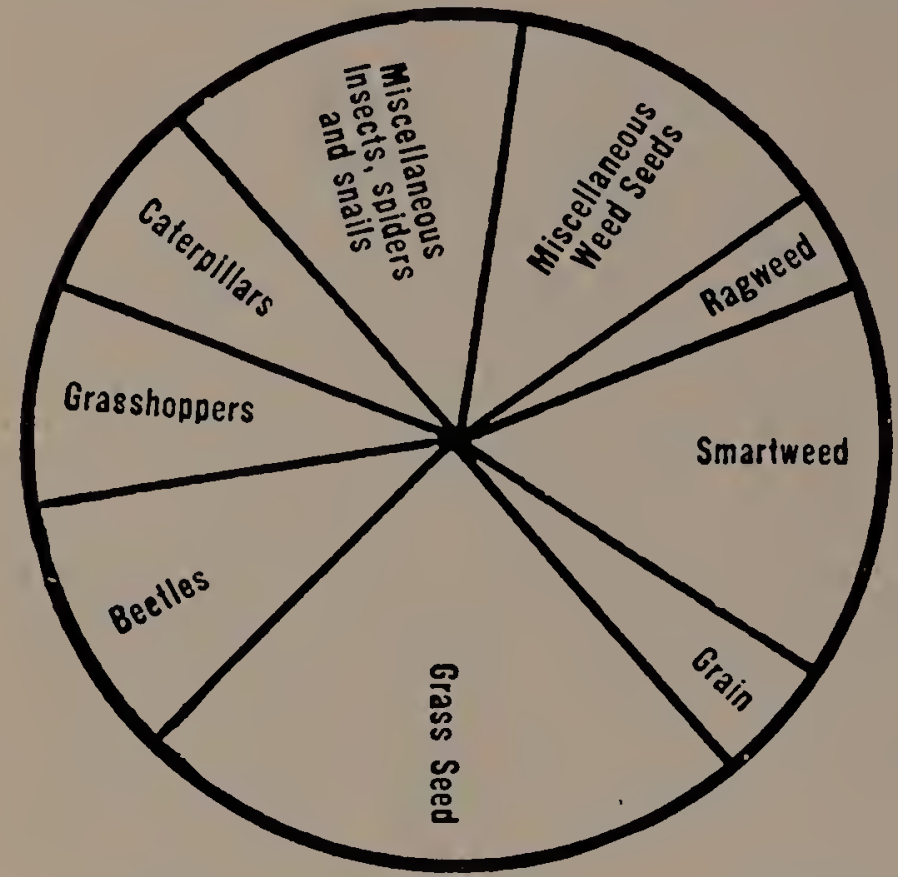

Fig. 9. Food of the Song Sparrow graphically shown. The relative size of the segments of the circle show the comparative amounts eaten of various foodstuffs. frequently it is found on the more elevated ground along fence rows, roadside banks, or about the home grounds.

Its food is much the same as that taken by others of the family, except that a greater percent of the seeds and insects taken are those found on low, moist ground. Thirty-four percent of its food is animal matter, chiefly insects. As a destroyer of smart-weed seeds, it is unsurpassed. Dock and sheep sorrel, eaten by but few species, are taken in quantity. Of the fruit and grain taken, a very little, 6 percent, is all that could be of use to man, and of the animal food, only 2 percent of beneficial insects could be considered as loss. The benefit resulting from the destruction of vast quantities of weed seeds as well as of injurious insects entitles it to protection.

ENGLISH OR HOUSE SPARROW, Passer domesticus

Without exception, all of our native Sparrows are of great service to man, but the reverse is true of the introduced House Sparrow. Its introduction took place at Brooklyn, N. Y., in 1851 and 1852, and since then it has spread over the greater part of the United States and Canada. In 1886, it added more than half a million square miles to the territory previously occupied by it. The first importation in to Ohio, direct from Europe, was in 1869 , when twenty pairs were sent to Cleveland. The same year thirty-three pairs were sent from New York to Cincinnati, Ohio and to Warren, Ohio; 1870 , in to Marietta; 1874, Coshocton and

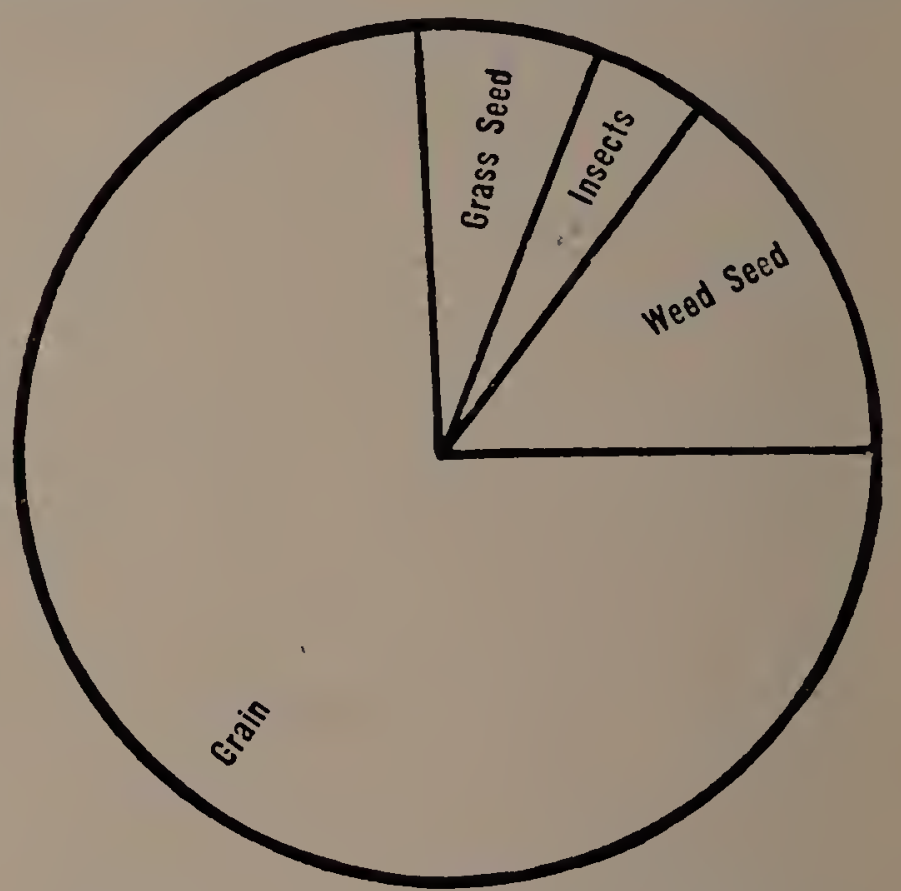

Fig. 10. Food of the English Sparrow, graphically shown. Portsmouth; 1880 or 1881, Steubenville; 1882, Wapakoneta, which seems to have been the last importation. (Jones.) 
They were first seen in Wayne county, Ohio, at Wooster, the fall of 1876, by Dr. J. H. Todd, and since the fall of 1877 have been permanent residents. Few are found far from the habitations of man, but wherever they can live at his expense, whether it be in rural communities or in the streets of great cities, they are to be found in great abundance. Their bulky nests frequently obstruct water conductors, and they are noisy and filthy about dwellings. Our native birds are driven away because of persistent persecution by this species. Eggs and young are destroyed, and nesting sites appropriated. Much damage is done to field and garden crops.

Its food is 98 percent vegetable, of which 74 percent is grain and 24 percent weed seeds. The 2 percent animal matter taken, consists almost entirely of injurious insects. Considered as a grain destroyer, it is a serious pest, but as a destroyer of our native birds, it is even more harmful. Its extermination by man is beyond hope, but it can be held in check, to a degree, at least, by the breaking up of nests, and the destruction of eggs and young whenever opportunity offers.

In rural districts, the persistent use of the shotgun will discourage this pest. Where the use of fire-arms is not advisable, box traps and poisoned grain are effective, but the greatest care should be exercised that useful species or poultry do not suffer.*

CARDINAL, Cardinalis cardinalis cardinalis (Linn.)

The Cardinal, Grosbeak or Redbird, is one of our most common and widely distributed birds. Once rare and confined to the undergrowth of woodland, it now frequents the shade trees of towns and cities, even nesting in the veranda vines or ornamental shrubbery of the home grounds. Its loud, but melodious whistle is one of the well known bird songs, and may be heard at any season of the year. At one time, it was the most popular species for caging, and further was so much sought for hat ornamentation that its extermination was threatened. The protection it has received at the hands of the law, within recent years, has resulted in its substantial increase.

Vegetable food, the greater part of which is weed seeds, is eaten in excess of animal matter. Corn is eaten more than other grain, but this consists largely of waste kernels that would otherwise be lost, or at least serve a less useful purpose. The fruits eaten are wild forms, of no use to man. Bark beetles, stink bugs, grasshoppers, crickets, caterpillars, saw-flies and ants are the most important injurious insects eaten.

* For further information, see Farmers Bulletin No. 838, U. S. D. A., "How to Destroy English Sparrows." 
ROSE-BREASTED GROSBEAK, Zamelodia ludoviciana (Linn.)

This species is of much less frequent occurrence than the preceding. It is a summer resident only in the northern part of the state, occurring in the southern part as a migrant. It is usually found in woodlands near rural dwellings, and is, therefore, of great economic value to the farmer.

Its food is similar to that of the Cardinal, except that animal matter is taken in excess of vegetable ( 52 to 48 percent). It is one of the few birds that eat the Colorado Potato Beetle. The vegetable diet consists of 15.74 percent weed seeds; 5.09 percent grain; 1.37 percent garden peas; 19.3 percent wild fruit; 6.5 percent miscellaneous, including cultivated fruit, buds, flowers and seeds of trees. The greater part of the animal food eaten is made up of destructive insects.

\section{BLACKBIRDS, ORIOLES AND RELATIVES}

The Icteridae, including the Blackbirds, Orioles and allies, is another distinctively American family. Great diversity of plumage and habits is found among members of this group; birds of brilliant hue, unsurpassed songsters, unique nest builders, and parasites are all represented. The Orioles, alone of the family, are non-gregarious, while most of the others are the most gregarious of our birds. The food comprises both vegetable and animal matter, the vegetable taking precedence for most species.

BALTIMORE ORIOLE, Icterus galbula (Linn.)

The first intimation that this Oriole has arrived in the spring, is the rich flute-like notes wafted to the ear on the perfume-laden air, as the bird gleans the insects from among the blossoms. The rich, flame-gold and jet of the male makes him, next to the Scarlet Tanager, the most brilliant and conspicuous of our birds. As a nest builder, this bird has no peer. The artistic and skillfully woven, pouch-shaped nest is suspended from the tips of a drooping branch. Of all trees, the American E1m is preferred for nesting. The nests vary in depth; those found away from human habitations are usually deeper than those found near dwellings; because of the greater protection afforded nests from their natural enemies in the latter situation, the greater depth is not necessary. Nestlings of this species are comparatively safe from owls, squirrels, or storms, while in the nest, but eggs are sometimes broken as the nest sways in the wind. 


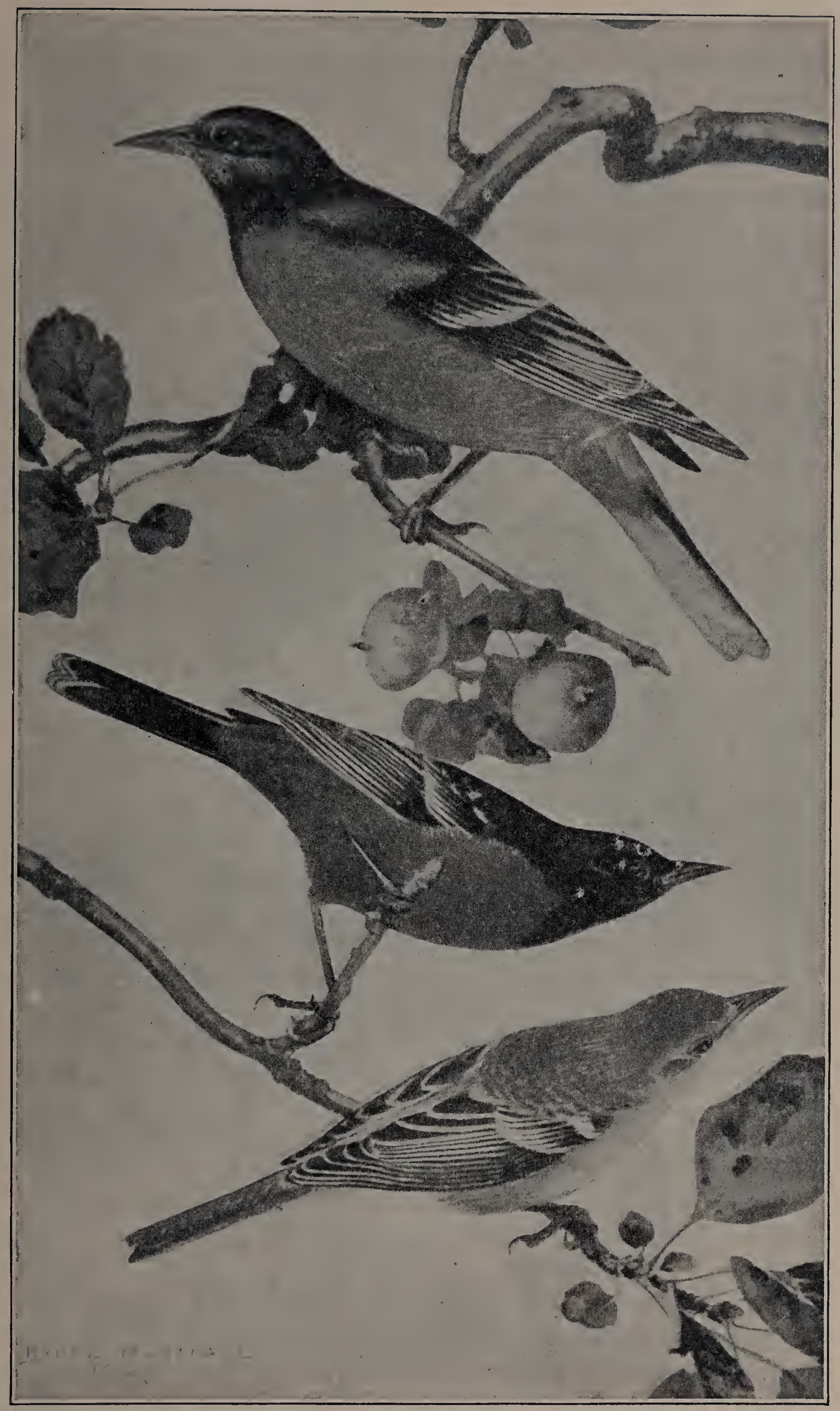

SOME USEFUL ORCHARD VISITORS

Fig. 11. Top figure, male Bältimore Oriole, Icterus galbula (Linn.); middle figure, male Orchard Oriole, Icterns spurius (Linn.); bottom figure, female Orchard Oriole. After Bulletin 29, Biological Survey, U. S. D. A. Photographed from Lithographic Plate by W. P. Beeching, $\mathcal{F}$. 
Insects compose 83.4 percent of the food, many of which are the worst pests of the garden and orchard, as well as of shade and forest trees. The most important item is caterpillars, which amounts to 34 percent, with beetles following a close second. Click beetles and their larvae, May beetles, leaf beetles, striped squash beetles and weevils are destroyed in large numbers, besides which, wasps, bugs, flies, aphids, scale insects, spiders and grasshoppers are taken in varying numbers. Fruit, grain, and weed seeds comprise the vegetable food ( 16.6 percent), but only a small part of this is taken from cultivated crops.

ORCHARD ORIOLE, Icterus spurius (Linn.)

This Oriole is not so well known as the more brilliant Baltimore Oriole, though it is not an uncommon bird. Its distribution is local, and very largely restricted to orchards; however, it sometimes frequents scattering trees along streams or in parks, but never dense timber. The food is very largely insectivorous, the arrival of the species occurring with the blossoming of fruit trees, with their attendant and abounding insect life. They are of particular service to the fruit grower, aiding him in his battle against the insect foes of the orchard. The only harm done is the taking of a few berries, which is trivial compared with the great good that comes through their destruction of insects detrimental to fruit and shade trees.

MEADOWLARK, Sturnella magna magna (Linn.)

This useful and handsome species was once considered a game bird and is, even yet, in a few states, where an open season is provided. During summer, it is common and of uniform distribution over the state, but is absent or much reduced in numbers in the northern part in winter. As its name implies, it is a lover of meadows and fields, especially old fields, and is sometimes called Old-field Lark. It is a Lark in name only, in reality a Starling. The song is loud but sweet, and is one of the conspicuous sounds of spring. The species feeds entirely on the ground, and 73 percent of its food is animal matter, consisting entirely of insects. It ranks high as a destroyer of grasshoppers, which reach 69 percent of its food in August, and even in January one percent is eaten. The saving to the hay crop alone by the destruction of this class of insects, justifies its protection. Beetles constitute about 18 percent of the food for the year, and includes May beetles; weevils, curculios and various leaf-eating beetles, while caterpillars and bugs form a constant, though varying portion. Weed seeds and grain in equal parts constitute the vegetable portion, the greater part of the grain being waste; no sprouted grain is taken. No bird is of greater economic importance on grass lands. 
BRONZED GRACKLE, Quiscalus quiscula aeneus (Ridgw.)

This is our common Blackbird, so abundant and well known throughout the state. They are always found in companies, varying from a few individuals to hundreds, or even thousands. They nest in colonies and are particularly gregarious in spring and fall, resorting to moist meadows and open woodlands to feed. At night, they return to an old established roost, usually the shade trees of a town or city, where they become more or less obnoxious, and from which it is difficult to drive them. Birds that are so highly gregarious are capable of doing much good or harm; therefore, a knowledge of the composition of their food is of great economic importance.

This species is omnivorous and, at times, when favorite food is not available, can subsist on anything digestible. Animal matter comprises 30.3 percent of the food for the year, 27 percent of which is insect. Many beetles, including May beetles, rose bugs and weevils, as well as grasshoppers, crickets, caterpillars and spiders, are destroyed in large numbers. As a destroyer of the white grub of the May beetle, it is well known, and if not molested follows close to the heels of the plowman, picking up the grubs as they are exposed by the plow. While in the nest, the food of the young is 75 percent animal matter, and during the same period, that of the adults is very largely insect. Vegetable matter comprises 69.7 percent of the food for the year, consisting of grain, weed seeds and fruits. Half of the vegetable portion is corn; the greatest injury to this crop being done when in the milk. The injury to sprouting corn probably has been overestimated, and many times this bird has been blamed for pulling corn when, had the truth been fully known, valuable service was being rendered through its destruction of cutworms and grubs. Plagues of insects following the wholesale destruction of Blackbirds, have been recorded since early colony days. Aside from the harm done to corn, some birds' eggs are eaten. But little injury is done to cultivated fruit, as the larger part eaten is of wild varieties. The beneficial qualities well balance the harmful; proper control of this species is not to be condemned, but wholesale destruction results disastrously.

RED-WINGED BLACKBIRD, Agelaius phaniceus phaniceus(Linn.)

More properly this should be known as the Red-shouldered Blackbird, since the scarlet is confined to the lesser wing covers (of the male.) This species is abundant wherever marsh-land occurs. The nesting is done in colonies, among rank growths of cat tails, sedges and marsh grasses. Since the draining of large areas of swamp lands, nests are quite commonly found in meadows or on dry 
ground, covered by low, bushy growth. One of the most familiar sounds of the marsh is the piercing note of alarm, or the rich, bubbling song of the male.

The food of this species is similar to that of the preceding. The vegetable portion is in excess of the animal matter, and comprises 74 percent of the total food. Most important of the $g$ rains eaten are corn, wheat, and oats, which together, comprise but 13 percent of the whole food; oats, which is largely waste grain, forms nearly half the amount. Weed-seed is the most important item of food and amounts to about 75 percent for the year. Among the most important weeds, the seeds of which are eaten, are ragweed, barn grass, smartweed, and a few others. Animal food comprises 26 percent of the entire food, of which ten percent consists of beetles, largely harmful species. Weevils comprise 25 percent of the food in June, and 4 percent for the year; grasshoppers amount to 5 percent. About 7-8 of the food of this species is made up of weed-seeds, or of insects injurious to agriculture. (Beal).

COWBIRD, Molothrus ater ater (Bodd.)

From its association with cattle, this species derives its name. It is a bird of very unusual traits, a parasite among birds. Its food is largely weed-seeds and injurious insects, and considered from its food habits alone, it is beneficial. The habit of depositing its eggs in the nests of other species results in the partial or complete destruction of eggs or young of the rightful owners. The smaller, beneficial insectivorous birds are usually victimized, and at least two of their young are sacrificed for each young cowbird reared. Mr. John Burroughs considers it detrimental and destroys eggs and young whenever he finds them. The English Cuckoo presents a parallel case, but our Cuckoos are not habitually guilty of this practice. BOBOLINK, Dolichonyx oryzivorus (Linn.)

Prior to the razing of the forest, this species was confined to the plains country. It was first seen in the state in Geauga and Franklin counties in 1857 . Since that time it has steadily increased, and, at the present time, is one of the few species, the increase of which is noticeable. It is resident in summer only in the northern half of the state, occuring as a migrant in the southern half. These birds love the open country, and are always associated in one's mind with broad meadows, particularly with clover fields. While in their breeding range, they feed and live on or near the ground, the nest being built in a depression. As a songster, the Bobolink is famous. During May and June the meadows are flooded with his gushing, bubbling melody, poured fourth while the singer perches on a swaying weed or while on the wing. 
While in the breeding range, the animal matter, largely insect, ymounts to 86.2 percent of the food eaten, the remainder being made up of weed seeds. The young are entirely insectivorous while in the nest. During the migration, this species causes a loss to the rice growers of the South, estimated at $\$ 2,000,000$. The wild rice upon which the bird once fed has given place to the cultivated crop, and this restricted area lies in the path of migration over which thousands of these birds pass twice each year. In the South, they are known as Rice birds, and great numbers are annually slaughtered. The Bobolink is deserving of protection in its breeding range.

AMERICAN CROW, Corvus brachyrhynchos brachyrhynchos Brehm.

The Crow is one of the most conspicuous birds of the ruraldistricts. It is common over the state, except in the northern portion during severe weather. Their cunning in evading the ruses of the most skillful gunner, and their shrewdness, when in captivity, indicate a high degree of intelligence.

Their food consists of both animal and vegetable substances in great variety.-insects, spiders, earth worms, snakes, frogs, lizards, small turtles, fish, snails, crawfish, mice, carrion, and the eggs and young of smaller birds. Their good and harmful qualities are about equally balanced.

BLUEE JAY, Cyanocitta cristata cristata (Linn.)

Its large size, bright plumage and loud notes, make the Blue Jay one of the most conspicuous of our birds. It is a common bird over the state, but is of more frequent occurrence in the northern part. It is one of the most familiar birds of the home grounds, both in town and country, but is met with away from habitations as well. The loud, varied notes are much in evidence during the spring, fall and winter, but are conspicuously absent in summer. Through its thefts of the young and eggs of other birds, it has made for itself an unenviable reputation. This is probably an individual trait, and not characteristic of the race as a whole.

The food is 24 percent animal and 76 percent vegetable matter. The animal food consists of mice, fish, salamanders, snails and crustaceans, which, with eggs and young of birds, a mounts to but one percent; the remainder of the animal portion being made up of beetles, grasshoppers, caterpillars, and other insects, 19 percent of which are noxious. Their favorite food is mast, acorns, beech nuts and chestnuts, and amounts to 42 percent of the food for the year. Wild fruits are also eaten, and in the fall a little corn is taken, comprising in September, 15 percent of its food, and thereafter constantly diminishing. The larger part of the corn eaten is waste grain, and of no use to the farmer. 


\section{FLYCATCHERS}

The group of birds known as the Tyrant Flycatchers is an American family, having no counterpart in the Old World. There is great variation in size, plumage, nesting babits, and in choice of habitat, but all are songless, insectivorous birds, procuring their food while on the wing. A dead branch, permitting an unobstructed view, is usually chosen as a perch, from which they make frequent short flights after insects, returning to or near the same limb after capturing their prey.

KINGBIRD, Tyrannus tyrannus (Linn.)

This well known Flycatcher is a common summer resident throughout the state. It is preeminently an orchard dweller and may be looked for wherever orchards are found.

Insects, mostly noxious, form 90 percent of the food, the remainder being wild fruit. The wide-spread prejudice among bee-keepers against this bird, because of the occasional destruction of honey bees by it, is without foundation. The examination of 218 stomachs of this species has proven that it is the exception, rather than the rule, that bees are taken. Of the stomachs examined, only 14 contained the remains of honey bees, four of which were with certainty identified as workers, forty were drones, and six were unidentified. This species is not only practically harmless to the interests of the apiarist, but a more than compensating benefit results from its capture of the robber-flies which prey on honey bees. The Kingbird's dislike for Hawks is well known and the feathered neighbors of this species are protected by it from the depredations of Hawks as well as of Crows.

PHOEBE, Sayornis phoebe (Lath.)

Of the Flycatchers, this species is the earliest to reach us in the spring as it is also the latest to depart in autumn. It arrives about the middle of March and lingers until late October. The nests of this species are probably more frequently infested with vermin than those of any other of our birds. Sometimes the parent birds are forced to abandon their young to their fate. Dusting with insectpowder (pyrethrum) will destroy the vermin without injury to the nestlings.

Ninety-three percent of the food consists of insects, chiefly noxious species, most important of which are click-beetles, Maybeetles, weevils, grasshoppers and flies. Two broods of young, of from four to six each, are usually reared in a season, the accomplishing of which results in the destruction of an enormous number of insects. When insects are not obtainable, vegetable substances, 
chiefly wild fruits, are substituted. It is one of tho most useful birds of the farm and frequently nests about sheds, springhouses, or porches, where it should be encouraged and protected.

RUBY-THROATED HUMMINGBIRD, Archilochus colubris (Linn.)

This well known bird is the only representative seen in the United States of this large and distinctively American family, the majority of the species being confined to the tropics. This most diminutive of our birds is always associated with the flower garden. To most persons, it is but a flash of color as it moves on rapidly vibrating wings from flower to flower. It is most frequently seen on the wing, but it often perches on a twig or arbor wire, to preen its plumage and to rest. The tiny, exquisitely fashioned, lichencovered nest is usually saddled on some low, drooping branch of a fruit or forest tree, and is a gem of bird architecture. The two very fragile white eggs are no larger than fair sized peas.

Besides the nectar of flowers, the food consists of the many small insects and spiders which are attracted to the blossoms. The young are fed by regurgitation.

CHIMNEY SWIFT, Chatura pelagica (Linn.)

This species is abundant over the entire state and is familiar to most persons. It is often, but er roneously, called Chimney Swallow. The curious, basket-like nest is constructed of twigs, and is usually fastened to the perpendicular inner wall of some chimney by a sticky secretion furnished by the bird. More rarely, the nest is fastened to rough boards close to the roof of a barn, or it is made in a hollow tree. Formerly, the species nested altogether in hollow trees. From two to six white eggs are deposited on the bare twigs of which the nest is constructed, no lining being used. Only one brood is reared in a season, the young occupying the nest for from three to four weeks. From earliest dawn until dusk has faded in to darkness, this valuable bird keeps up its tireless pursuit of the insect foes of man and beast. It is the most aerial of our birds, not touching the ground, even when collecting nesting material, but snapping the dead twigs from trees while on the wing.

NIGHTHAWK, Chordeiles virginianus virginianus (Gmel.)

The Nighthawk or Night Jar is a common summer bird throughout the state. It is a bird of the open country, and feeds while on the wing. It seldom feeds below the level of the tree tops, but usually much higher. The two elliptical eggs are deposited on the bare ground, in an open field, with no attempt at nest-building, other than taking advantage of any slight depression which offers. Not infrequently, eggs are deposited on the graveled roofs of tall city buildings. 
The rasping call-note is uttered frequently while the bird is on the wing, which characteristic booming sound is produced by the air rushing through the wing quills as the bird, with great rapidity, rushes earth-ward on set wings. A large white patch in each wing, which is easily seen when the bird is in the air, is a good distinguishing mark.

WHIP-POOR-WILL, Antrostomus vociferus vociferus (Wils.)

This species and the preceding are frequently confounded. The Whip-poor-will is the more terrestrial and is confined to the heavier timber, where it nests, the two elliptical eggs being deposited on the dry leaves beneath the undergrowth. In consequence of this choice of habitat, its occurrence is local. To many, the bird is but a wandering voice, being known only by the familiar call from which the bird derives its name. The insect food of this species is composed of such forms as are flying abroad at night and are taken near the ground.

\section{WOODPECKERS}

The Woodpeckers are guardians of the forests, and their dis$t$. ibution depends largely upon the presence of timber. The stiffpointed tail feathers, which assist them to sustain their weight against tree trunks, their strong, chisel-like bills and barbed, distensible tongues, admirably fit them for the destruction of wood-boring larvae and other forms of insect life, inaccessible to most other birds. The uniformly glossy white eggs are deposited in cavities, usually excavated by themselves. All are songless, but have call-notes. The drumming of the male seems to take the place of song, and is produced by the vigorous and rapid striking with the bill on a dead, resonant branch.

\section{RED-HEADED WOODPECKER, Melanerpes erythrocephalus (Linn.;}

Our commonest summer wood pecker, at least locally; it usually winters, even to the lake shore, in small numbers. It prefers open woodland, parks or orchards. The black, white, and red plumage of this species makes it one of the most conspicuous of our birds. The capturing of insects, after the manner of the Flycatchers, is quite characteristic, and they sometimes repair to the ground for food. Beetles and grasshoppers form 36 percent of their food. Some corn, wild and cultivated fruit, acorns and other mast, is also eaten. The few berries and cherries and the little corn that is eaten is more than compensated for by the injurious insects destroyed. Live wood is not injured by this species.

NORTHERN FLICKER, Colaptes auratus luteus (Bangs.)

The Flicker, also called Golden-winged Woodpecker, Pigeon Woodpecker, Yellow Hammer, and by many other names, varying 
with the locality, is the largest common species of the family, found generally throughout the state. In winter, their numbers are much diminished and they are confined to the more protected lowlands. The nest may be near the top of a lofty forest tree, or in a shade or orchard tree, but a few feet from the ground. Unlike other members of the family, this species is more or less terrestrial in its habits, and is frequently seen on lawns, feeding on ants which compose its favorite food. More than three thousand of these insects bave been taken from a single stomach. Grasshoppers and crickets are eaten in large numbers. In some states the Flicker is classed as a game bird, but it is of too great economic value to be sacrificed for food.

\section{YELLOW-BELLIED SAPSUCKER, Sphyrapicus varius varius (Linn.)}

This species is the only injurious member of the family found within the state. A large part of its food consists of the cambium layer (inner bark) and sap of trees. It works la rgely on the live wood, the holes, usually arranged in rows, varying greatly in size. Through these wounds the spores of various fungi enter, resulting in the disfigurement or, if completely girdled, in the death of the tree. It is common only as a migrant in spring and fall; a few nest in the north and some winter in southern Ohio. The injury done in the state is probably not very great; it is, perhaps, most serious to ornamental and shade trees, including both deciduous kinds and evergreens. This species

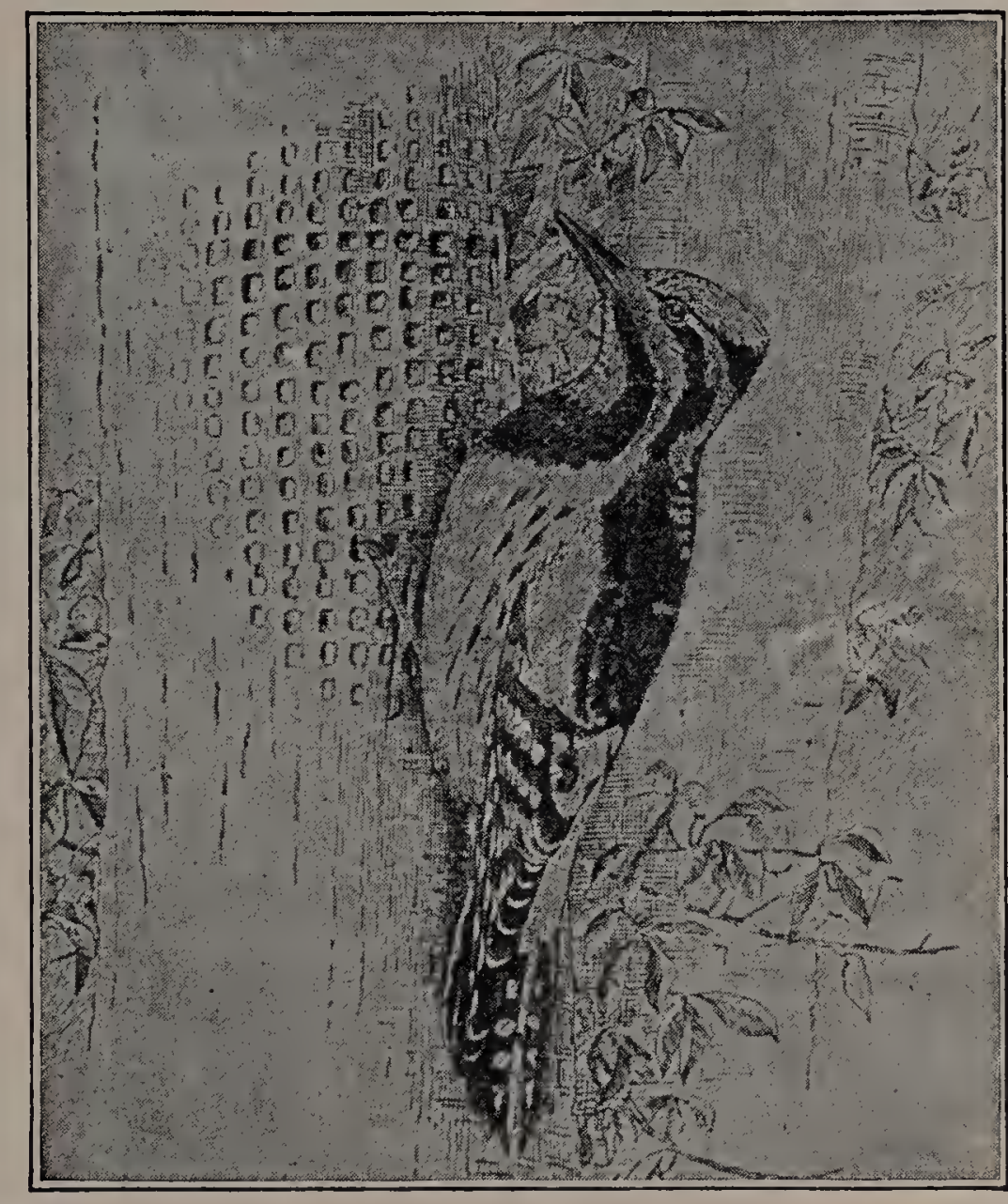

YELLOW-BELLIED SAPSUCKER, Sphyrapicus varius varius $($ Linn.)

Fig. 12. After Bulletin 39, Biological Survey, U. S. D. A. may be distinguished from the Downy Woodpecker, with which it is sometimes confounded, by its larger size, black band across the breast, and pale-yellow lower breast and belly. Its call note is weak, and suggests that of the Catbird. 
RED-BELLIED WOODPECKER, Centurus carolmus (Linn.)

This Woodpecker is more common in the southern part of the state than northward, but is resident the year round, wherever found. It shows a preference for moist, wooded bottom-land, and its loud call-note is sure to attract attention. Its usual diet of worms and insects is varied by wild fruit, acorns, beechnuts and sometimes apples. Whatever loss is occasioned by its fondness for cultivated fruits is fully atoned for by its destruction of injurious insects. This is one of the most beautiful and useful members of this valuable family.

DOWNY WOODPECKER, Dryobates pubescens medianus (Swains.)

This is the smallest of our Woodpeckers and occurs in all parts of the state, being equally common both summer and winter. It is found in deep woodland, in orchards, or on the shade trees of city streets. The food consists of injurious insects, their eggs andlarvae.

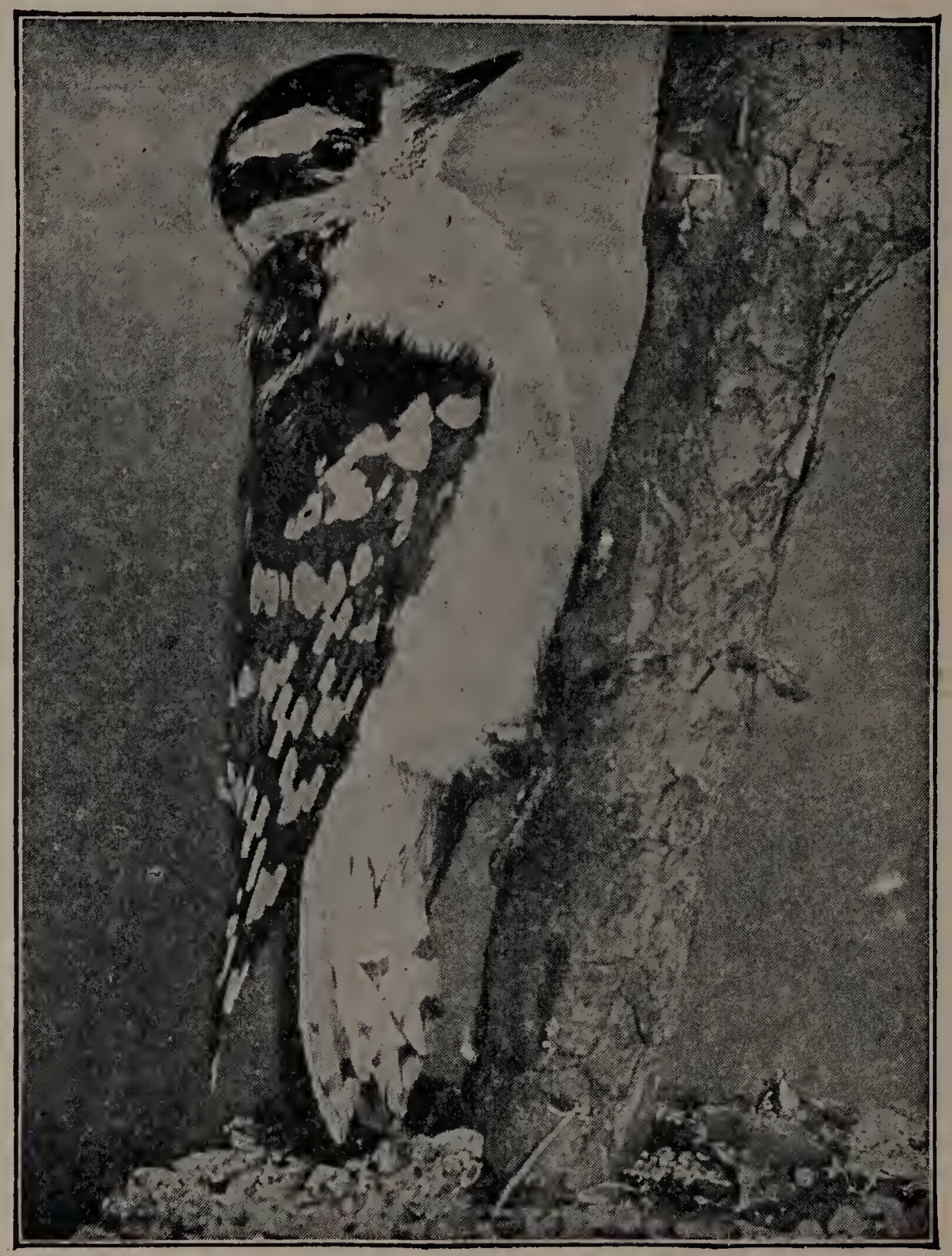

DOWNY WOODPECKER, Drrobates pubescens medianus (Swains.

Fig. 13. After Washburn, Ninth Annual Report, State Entomologist of Minnesota. 
This usefulbird is sometimes referred to as a Sapsucker, but wrongly, as no injury is done to the living wood of trees. It is of great econJmic value to man and should receive encouragement and protection. A piece of suet, marrow, bone, or some cracked nuts, placed out of reach of cats, will be frequently visited during cold winter days.

HAIRY WOODPECKER, Dryobates villosus villosus (Linn.)

The Hairy Woodpecker is nearly the exact duplicate of the Downy in color, but its larger size and stronger voice serve to distinguish it. The Hairy is a lover of woodland, and is not so frequently found on city shade trees. The food habits of the two species are almost identical.

BELTED KINGFISHER, Ceryle alcyon (Linn.)

The persecution visited upon this species by gunners has made the Kingfisher a wild, shy bird. The wide-spread prejudice against it among anglers and sportsmen is caused by the belief that the species is detrimental to game fishes, whereas few fish, if any, that are of value to man, are eaten. Whatever fish are taken are small, since large ones can not be swallowed. Crawfish and other forms of invertebrate, aquatic life are more extensively consumed than fish. Grasshoppers, crickets, and other insects form an important item of food. This useful species, because of its beauty and association with our water courses, is deserving of the fullest protection.

YELLOW-BILLED CUCKOO, Coccyzus americanus americanus (Linn.)

Perhaps this bird is best known by the name of Indian Hen or Rain Crow, especially in rural districts. To the old settler, its call was a prediction of rain. It is a common and uniformly distributed species over the state. Arboreal, shy and suspicious, living in retirement amid the dense foliage, it is much more frequently heard than seen. It is not, however, confined to the forests, but frequents the shade trees of towns. Its notes, while not musical, are not unpleasing and are quite varied. In matters pertaining to housekeeping, it is careless. The nest is a rudely constructed platform of sticks placed in bushes or small trees at no great distance from the ground, and is frequently so loose that the eggs may be counted from beneath. The eggs are greenish-blue, elliptical, about the size of a robin's, and usually two to four in number. Occasionally, the eggs of one or the other of our Cuckoos are found in the nests of other birds; but they are not parasites to the same extent as the English Cuckoo or our Cowbird. About 50 percent of their food is composed of caterpillars, the larger part of which are spiny or hairy forms, commonly rejected by other birds. Grasshoppers, beetles, and many kinds of bugs, flies, and other insects are taken in varying proportions. Grasshoppers comprise 75 percent of the food for September; rarely, a little fruit is eaten. 
BLACK-BILLED CUCKOO, Coccyzus erythrophthalmus (Wils.)

This species is not so well known as the preceding and is, without doubt, frequently mistaken for it. As a migrant, it appears to be fairly common and occurs to some extent as a summer resident, at least in the northern part of the state. The food habits of the two species are identical. This species may be known from the preceding by its slightly smaller size, absence of rufous (rust-red) in the wings, and likewise absence of black in the tail and of yellow on the lower mandible.

\section{OWLS}

The Owls have always been regarded with more or less superstition because of their weird cries, not unlike the human voice, and their association with darkness. They are the nocturnal birds of prey and are of even greater im portance to agricultural interests than the Hawks, as a greater percentage of their food consists of small mammals, the majority of which inflict their damage under cover of darkness. With few exceptions, they are woodland dwellers. The flight of these birds is noiseless and graceful.

BARN OWL, Aluco pratincola (Bonap.)

In the southern part of the state and locally, this Owl is more or less common. It is much larger than the Screech Ow1 and may readily be distinguished by its monkey-like face and lack of eartufts. Its days are passed in retirement in barns or other buildings, and here it also nests. The food consists almost wholly of mice and rats; one of these birds will destroy more of these destructive rodents than a dozen cats. Poultry or birds are rarely, if ever, taken. This species not infrequently nests in dove-cotes or boxes placed high up near the ridge of the barn roof. There should be an opening in such boxes, communicating with the outside. Access to the inside of the barn should also be provided, that mice and rats may be destroyed. Because of its choice of abode and the character of its food, it is of greater economic value, individually considered, than any other of the Raptors and should receive the fullest protection.

SCREECH OWL, Otus asio asio (Linn.)

This little Owl is our most common species; the smallest of the family, with prominent ear-tufts and is the Great Horned Owl in miniature. There are two color phases - the red and gray-the cause of which is not understood, but neither sex nor age seems to have any influence in determining it, since both phases appear in the same brood, even when the parents are of the same color. 


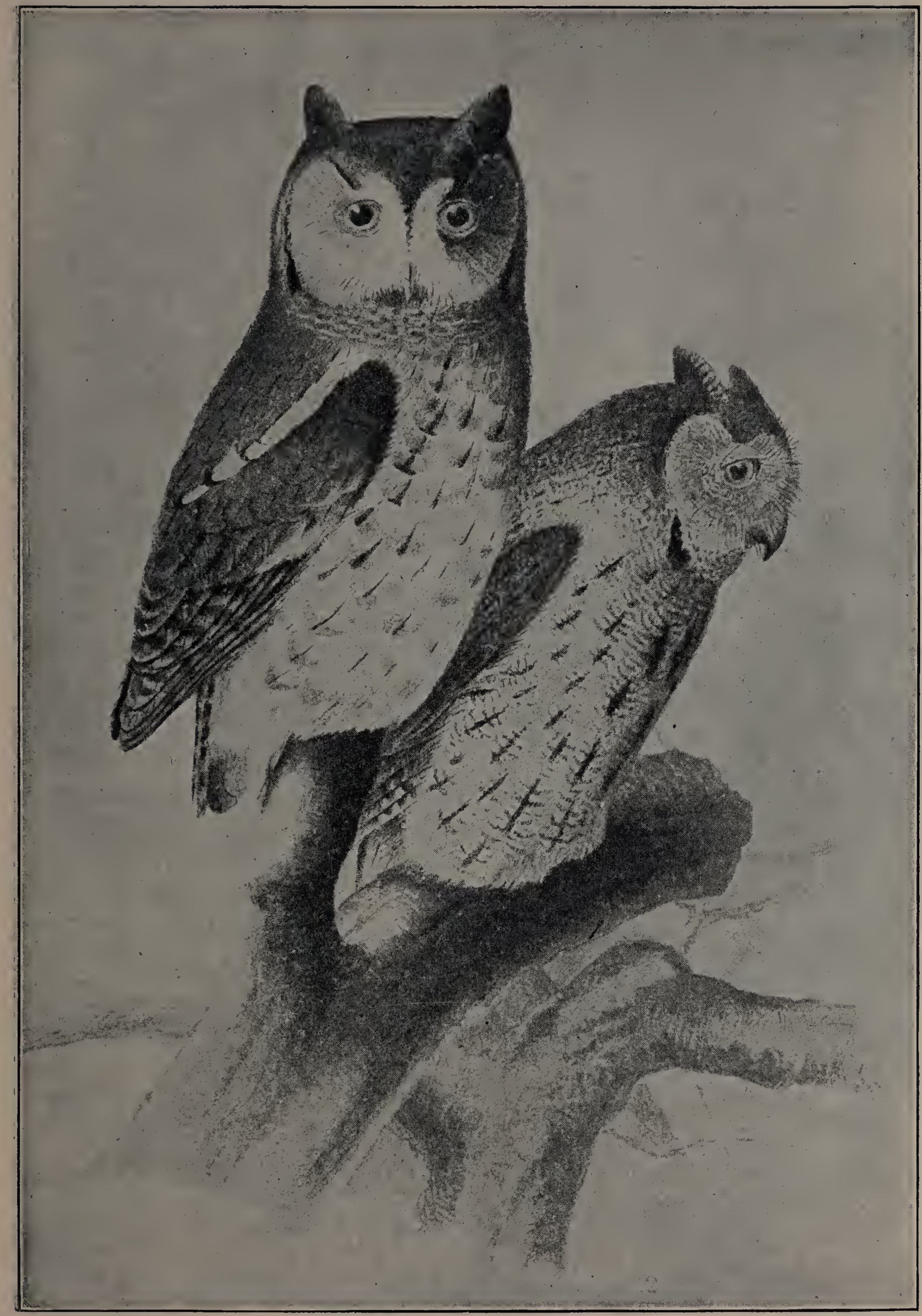

SCREECH OWL, MALE AND FEMALE, Otus asio asio (Linn.)

Fig. 14. After Bulletin No. 3, Division Ornithology and Mammalogy, U. S. D. A. Photographed from lithographic plate. 
Its call is a series of soft, tremulous notes, weird and pathetic, but not unmusical. It prefers to live near man, where its destruction of mice and vermin is of great benefit. Its diet is composed of a great variety of animal life. In town, House Sparrows compose its chief food. It usually hunts during the twilight hours after sunset and before dawn, or on moonlight nights. During the day it seeks the seclusion of a hollow tree where its presence is often revealed by the Blue Jays. This Owl takes advantage of a box in which to rear its young, and more useful tenants could not be found.

BARRED OWL, Strix varia varia (Bart.)

Of our resident species, second in size only to the Great Horned Owl, from which it is readily distinguished by the absence of eartufts and by its smaller size. It is restricted to woodland, dense

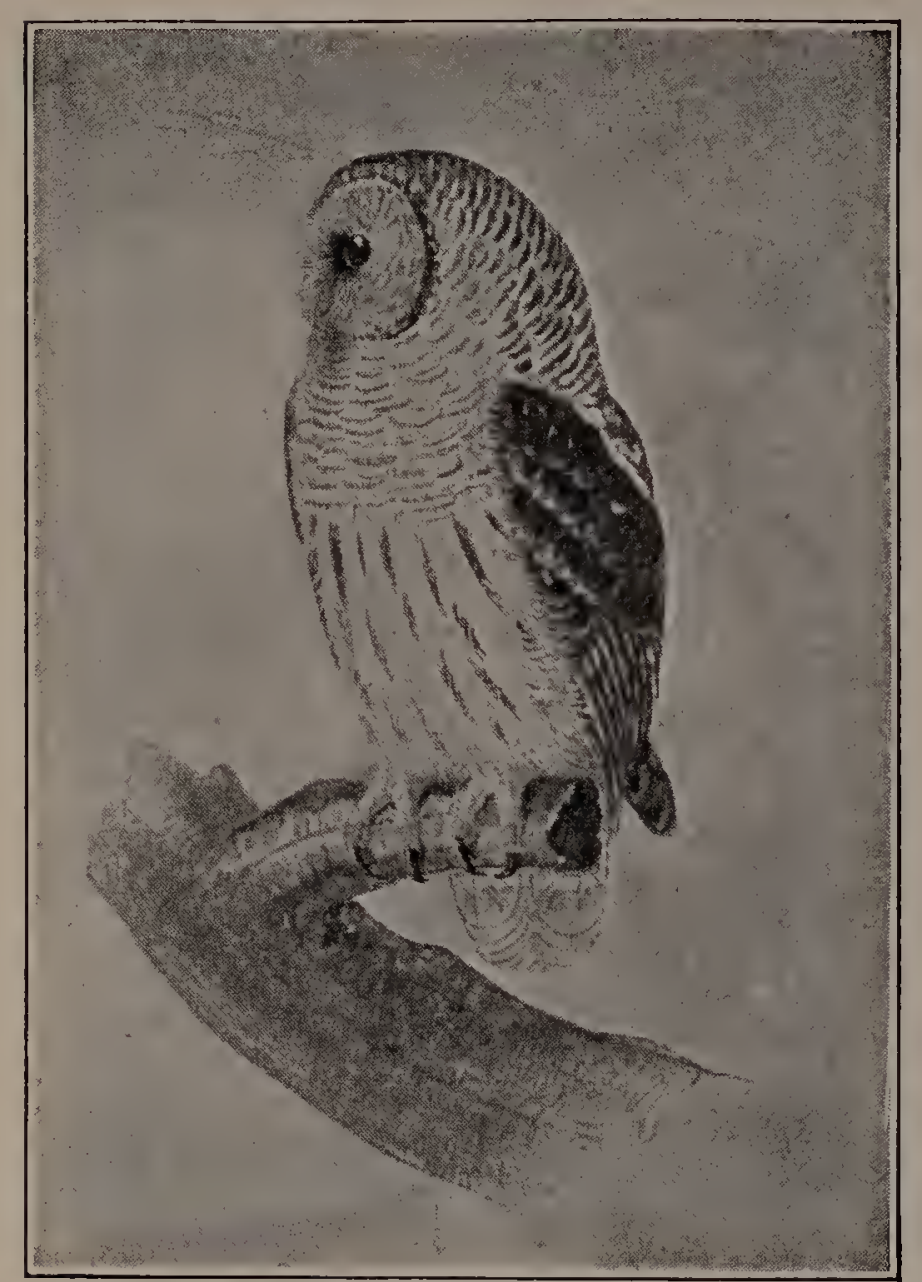

BARRED OWL, Strix varia aria (Bart.)

Fig. 15. After Bulletin No. 3, Div. of Ornithology and Mammalogy, U. S. D. A. Photographed from lithographic plate.

more or less destructive. Much of the harm done by the Great Horned Ow1 is mistakenly charged to the account of this useful species.

GREAT HORNED OWL, Bubo virginianus virginianus (Gmel.)

The largest, most powerful and destructive member of the family breeding within the state. Like the preceding species, it prefers the more densely wooded lowlands, where it hunts by night 
and occasionally by day, especially if young are in the nest. In lieu of a hollow tree, the abandoned nest of a Hawk or Crow is used, the eggs being usually deposited by the middle of February. Not infrequently the eggs are spoiled by freezing during unusually severe weather. This Owl is the most destructive of all our Raptors. Poultry of all kinds, including turkeys, all kinds of game birds, also Hawks and other Owls, with rabbits, squirrels, skunks, opossums, muskrats, and the smaller mammals, comprise the usual fare. If provender is plentiful, little except the heads of its victims are eaten. The depredations committed by this murderous Owl have brought maledictions on the heads of the useful species, both innocent and guilty suffering alike. In justice to the more beneficial members of the family, this species should be shown no mercy.

LONG-EARED OWL, Asio wilsonianus (Less.)

This $\mathrm{Owl}$ is probably more common than it appears to be, but because of its quite strictly nocturnal habits, it is not very frequently observed. Like most of the family, it is a bird of the woods. It is the only medium-sized Ow1 with prominent ear-tufts. Identification is easy, since it is so much larger than the Screech Ow1 and so much smaller than the Great Horned Owl. Mice and other small rodents, almost exclusively, comprise the food, and birds are seldom touched. It is one of the most beneficial of all Raptors and deserves full protection.

SHORT-EARED OWL, Asio flammeus (Pontop.)

Unlike the Owls in general, this species frequents open meadows or swamp-land, where it hides in the rank growth of grasses and weeds on bright days, and hunts during cloudy weather or by twilight. It hunts near the ground, seldom above three feet, and its flight is noiseless, easy and graceful. The nest is built on the ground among the herbaceous growth. Its principal diet is small rodents of which a very large percentage are destructive meadow mice. This species, with the Long-eared and the Barn Owl, forms a trio of feathered servants which is of very great economic importance to the agriculturist.

\section{HAWKS AND EAGLES}

Falcons, Hawks, and Eagles, are the durenial or daylight birds of prey. They are solitary birds, except during the breeding season, and resent the intrusion of others of their kind within the limits of their hunting range. In keeping with their cruel natures, their cries are loud and piercing, striking terror to the hearts of smaller creatures in fur and feathers and causing them to seek cover. With but few exceptions, these birds are beneficial and constitute nature's 
check on destructive rodents that are abroad by day. Poultry and birds are taken to an injurious extent by only a few species. The powerful talons are used to strike their quarry, and the characteristic, powerful, hooked beak is used in rending it. The nests of the majority of species are built of sticks, with some grass or finer material for lining. When not molested, the same nest is used year after year, growing bulkier each season with the addition of new material.

MARSH HAWK, Cırcus hudsonius (Linn.)

The occurrence of the Marsh Hawk or Harrier is quite local; it is more frequently met with in summcr than during winter, but is not common at any time or place. It differs from other members of the family in perching and nesting on the ground. In hunting, it keeps near the ground over meadow or swampland. It is one of the larger Hawks and may be known at any season by the conspicuous white rump-patch at the base of its long tail. Its wings are long; the flight, easy and graceful, is accomplished with no apparent effort. It is more sociable than most raptorial birds and frequently hunts in pairs. During migrations, straggling flocks of from forty to fifty are sometimes seen. The character of its food makes it one of the most valuable among the birds of prey. Meadow mice comprise the favorite food, and these with ground squirrels and other rodents, frogs, snakes, grasshoppers, and crickets complete the usual fare. Unless pressed by hunger, because of a scarcity of the usual food, poultry or birds are se1dom taken; then, only seed-eating species and wounded game birds are preyed upon. Protection should beafforded this worthy species.

SHARP-SHINNED HAWK, Acciputer velox (Wils.)

This Hawk, as well as all others of the genus, has a decided liking for poultry and birds of all kinds, taking them in preference to other food. They are the true "Chicken Hawks", despite the fact that the larger and more beneficial members of the genus Buteo are generally referred to as such. This species is the smallest of the trio of destructive Hawks, among which the closely allied Cooper's Hawk and the Goshawk are included. It is one of the smallest of all our hawks, being but little larger than the Sparrow Hawk. The tail is long and square-ended; the wings short. Unlike other Hawks, it does not hunt in the open but pounces upon its quarry from some leafy retreat. This species is bold and daring, frequently attacking and bringing down birds as large or larger than itself. The excess of useful birds and poultry over mice and insects, comprised in the food of this species, results in an economic 
loss. Occasionally the Sharp-shinned Hawk does some good in towns and cities $b_{y}$ its destruction of House Sparrows. In justice to the

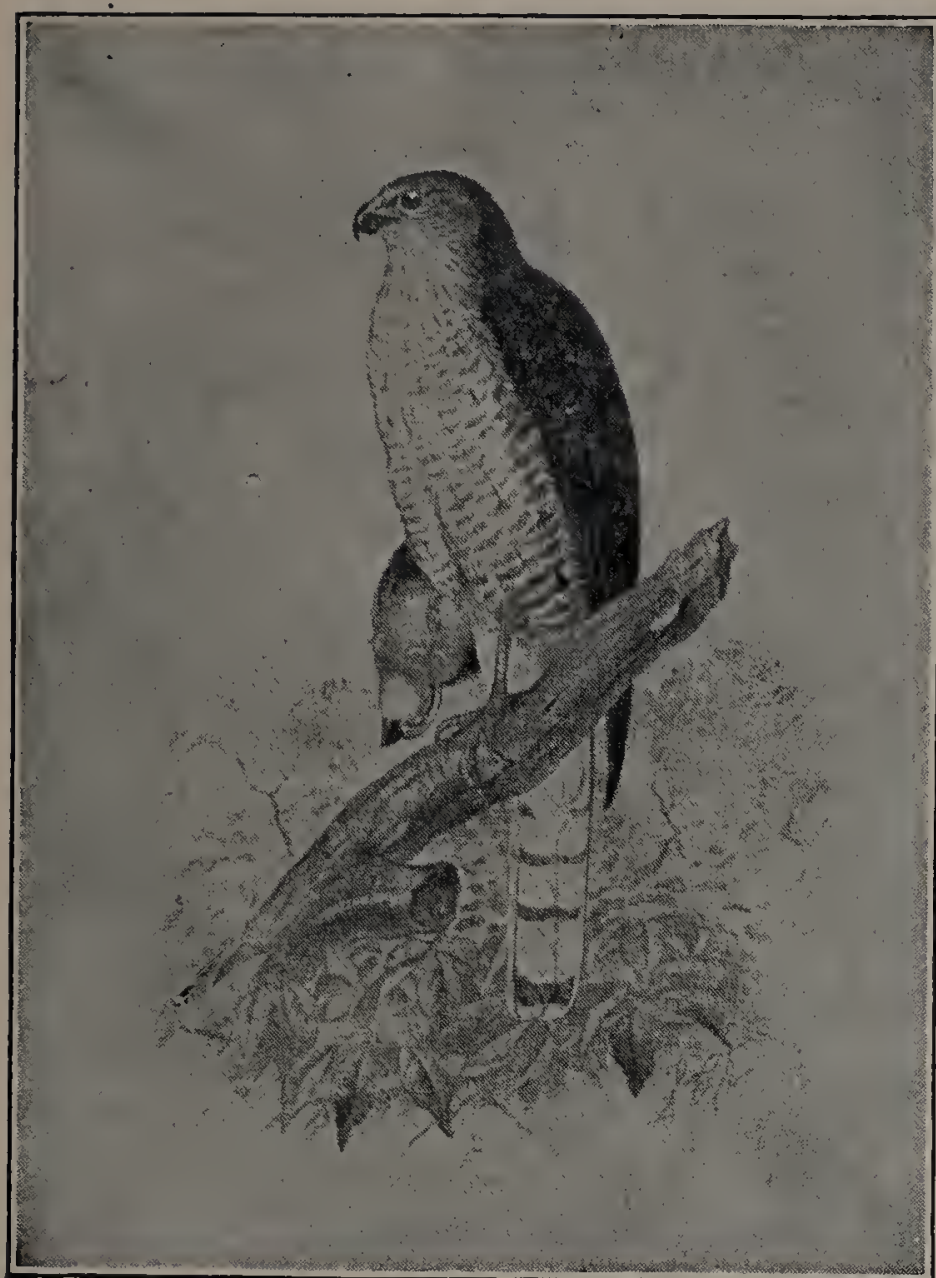

SHARP-SHINNED HAWK, Accipiter velox (Wils.)

Fig. 16. After Bulletin No. 3, Division Ornithology and Mammalogy, U. S. D. A. Photographed from lithographic plate.

devious way through the openings in the undergrowth of the forest. It is more destructive than the preceding species, because it occurs more commonly, and also its larger size and greater strength enable it to destroy larger game. Poultry suffers more from the inroads of this species than from other Hawks; young chickens, especially, up to full grown pullets are taken. When visits to the poultry yard are begun the use of the shotgun is the only remedy. sometimes kills House Sparrows, beneficial Hawks, this species, as well as Cooper's and the Goshawk, should be destroyed whenever possible.

COOPER'S HAWK, Accipiter cooperi (Bonap.)

Very similar to the preceding in everything excepting its larger size and rounded tail, is the Cooper's Hawk. Its flight is easy and irregular, save when in pursuit of a bird it becomes swift and direct, and with perfect ease it always threads its

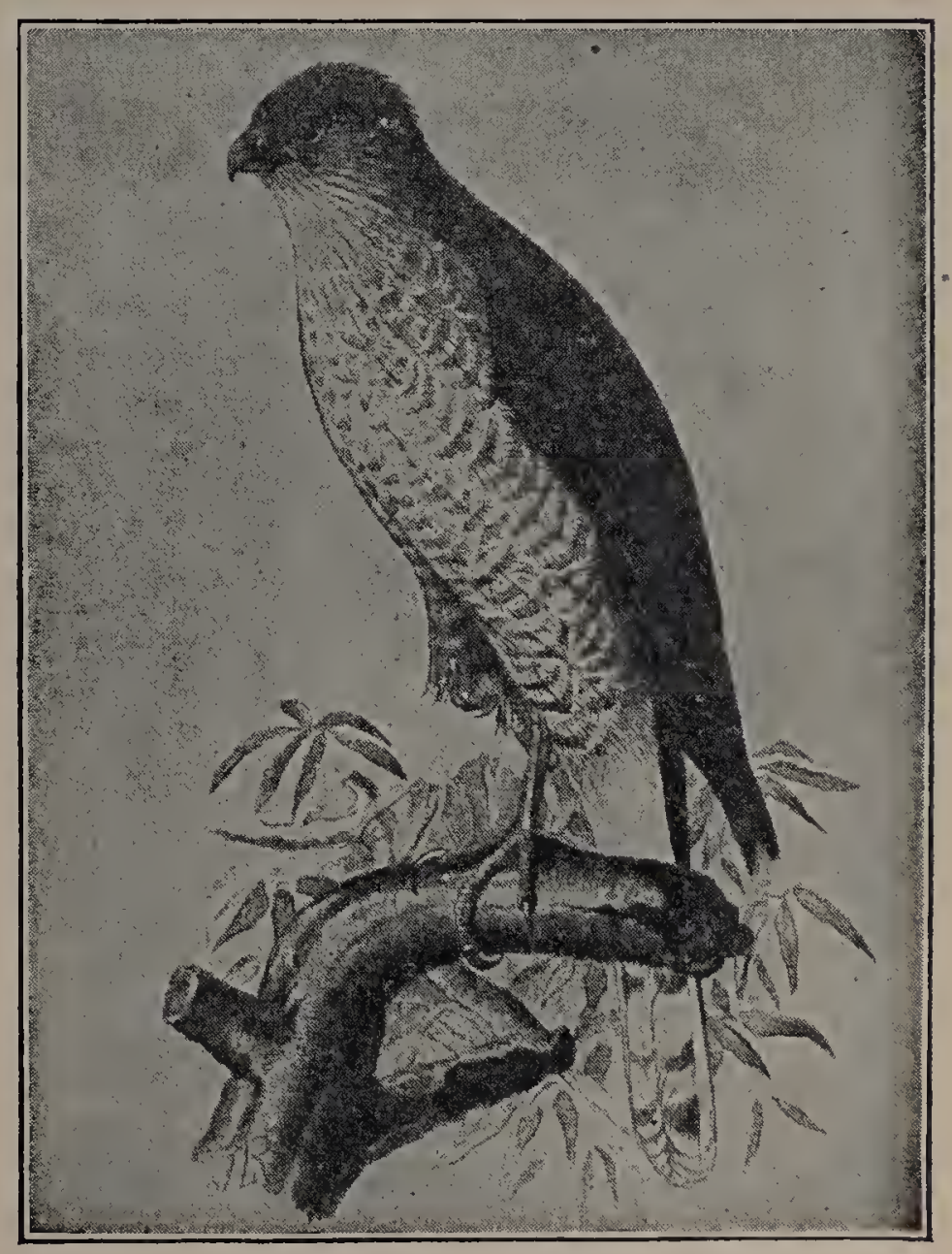

COOPER'S HAWK, Accipiter cooperi (Bonap.)

Fig. 17. After Bulletin No. 3, Division of Ornithology and Mammalogy, $U$. S. D. A. Photographed from lithographic plate.

Like the preceding species, it but on the whole is detrimental. 
GOSHAWK, Astur atricapillus (Wils.)

The most destructive representative of the hawks is the Goshawk, but it is of such rare occurrence in the state that, from an economic standpoint, it need not be considered. The food is similar to that of the two preceding species, except that larger game is taken. In consideration of its food propensities, no regret need be felt that it is scarce and is becoming scarcer.

RED-TAILED HAWK, Buteo borealis boŕalis (Gmel.)

Of the three representatives of the genus Buteo found in the state, the Red-tailed Hawk is the largest and most powerful. This species and the closely related Red-shouldered Hawk are commonly referred to as "Chicken" or "Hen" Hawks, but wrongly, as they are among the most beneficial of the birds of prey. Its movements are slow and deliberate, lacking the dash and daring of the Sharp-shinned Hawk and its nea rest congener. Sometimes it will soar for hours, describing wide circles and ascending to a great height, even passing beyond the range of human vision. Because of its size, and also because of being one of the more common species, its influence for good or evil to agricultural interests makes the study of its food a matter of great economic importance. The farmers, who as a class derive the greatest benefit from them, are the most pronounced enemies of these valuable birds, because of the mistaken belief that they feed on poultry; whereas, the food consists of mice, shrews, and other destructive rodents up to the size of woodchucks, besides frogs, toads, crawfishes, snakes, lizards and various insects. Poultry, birds, and all other useful animals, including snakes and toads, do not amount to 15 percent of the entire food. Birds and poultry are most commonly taken late in the fall and winter, the victim usually being an old barnyard fowl or some wounded game bird, since these are most easily obtained and the result is little or no loss. (Fisher). Individuals of this, as well as of other beneficial species, have been known to become poultry thieves, but such instances are exceptional; when this is the case, the shooting of such individuals is justifiable.

RED-SHOULDERED HAWK, Buteo lineatus lineatus (Gmel.)

In habits, this hawk is very similar to the preceding. Its smaller size and bright rufous wing-coverts serve to distinguish the two species. The call note of the Red-shouldered Hawk is a fierce kee-you, kee-you, repeated a number of times while sailing majestically aloft on set pinions. The diet of this species is more varied than that of most birds of prey, and comprises mammals, birds, snakes, frogs, fish, insects, centipedes, spiders, crawfishes, earth.worms, and snails. It is especially fond of frogs, yet mice furnish fully 65 percent of its food, aside from other small mammals such as squirrels, 
young rabbits, shrews and moles. Poultry is seldom touched, except in the form of offal. It is impossible that any except disabled birds are taken by this slow flying hawk. (Fisher). This is the most abundant large Hawk in most sections of the state. Prejudice should be laid aside and protection given to this valuable species.

SPARROW HAWK, Falco sparverius sparverius Linn.

The commonest as well as the smallest and best known of our Hawks. It is a resident species in all parts of the state, but is less common during the winter, particularly in the northern counties. Its call is a series of high pitched notes, sounding like kil-ly-kil-lykil-ly-kil-ly, uttered in rapid succession, and is a familiar sound in towns and cities, where it goes in pursuit of House Sparrows. In the country, this little Falcon hunts over meadows for its favorite diet of grasshoppers and crickets. Its flight is not usually rapid, and is frequently arrested, while on hovering wings, the bird scans the ground for signs of prey. Like most Raptors, this species remains paired through life. Either a natural cavity or the unused excavation of a Flicker is usually chosen for a nesting site. It is very courageous in defence of its young, driving off even the Red-tailed Hawk, if one appears in the vicinity of the nest; with the same zealous care, it guards its hunting ground against intrusion. Its diet is largely insects; grasshoppers, and crickets when plentiful, comprising the bulk; at other times, the deficiency is made up of other insects, of spiders, small rodents, snakes, lizards, and small birds. That this species suffered more, when bounty was paid for the destruction of Hawks, than any other species, is confirmed by $\mathrm{Mr}$. W. B. Hall of Wakeman, Ohio, as follows: "The Sparrow Hawk is a most persistent enemy of the grasshopper tribe. While the socalled Hawk law was in force in Ohio, I was township clerk in my native village and issued certificates to the number of eighty-six, forty-six being for the Sparrow Hawk. I examined the stomachs, and found forty-five of them to contain the remains of grasshoppers and the elytra of beetles, while the remaining one contained the fur and bones of a meadow mouse (Avicola riparius)." This useful bird, under the name of Mouse Hawk, is now specifically mentioned in the list of protected species. 


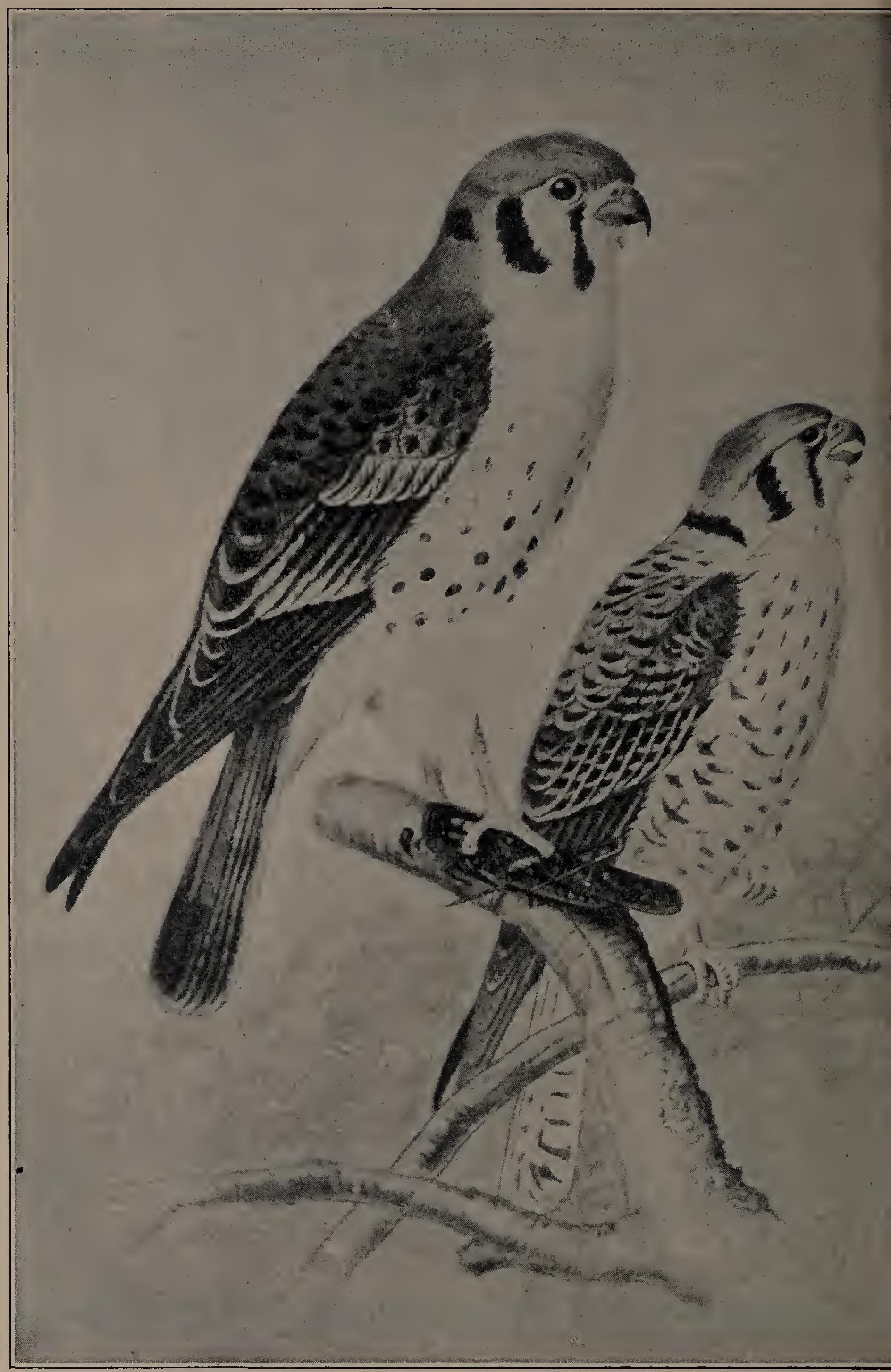

SPARROW HAWK, male and female, Falco sparverius sparverius (Linn.)

Fig. 18. After Bulletin No. 3, Division of Ornithology and Mammalogy, U. S. D. A. Photographed from lithographic plate. 


\section{VULTURES}

The Vultures belong to the Raptors, but their food habits differ greatly from others of the group. These birds are scavengers, gorging on offal and carrion, while they seldom prey on living animals. They do not take putrid flesh from choice, but because it is more easily torn by their bills, which are not so strong as in other rapacious birds; also the feet are less formidable than in other members of the group.

TURKEY VULTURE, Cathartes aura septentrionalis Wied.

The Turkey Vulture, commonly called Turkey Buzzard, is a common resident in southern Ohio, and locally throughout the northern part in summer. While in the air, the bird is extremely graceful, the flight being accomplished with no apparent exertion or perceptible motion of the wings. When not gorging or gorged, much of its time is spent on the wing. If one would retain the impression received from the majestic flight, too close inspection when in a state of repose, is not to be desired; when on the ground, it is awkward and ungainiy; its head and neck are destitute of feathers. This bird renders an important service to man in disposing of decaying flesh that would otherwise pollute the air and breed sickness. Where Vultures are abundant, dead animals are not buried, but are dragged to an out of the way place and left to the disposal of these birds. These unclean feeding habits have led some observers to suspect that these vultures are often responsible for the transmission of the germs of hog cholera and similar diseases from one locality to another. This suspicion seems to rest wholly upon a guess, which may or may not prove to be true. Investigation of this question ought to be made in regions where the birds are abundant. Without more knowledge than is possessed at present, the laws of those southern states which prohibit the slaughter of the Turkey Vulture seem to have been wisely enacted.

MOURNING DOVE, Zenaidura macroura carolinensis (Linn.)

One of the most familiar of our birds is the Mourning Dove, so named from its mournful call. It is a ground feeder and, except during the nesting season, is found in small flocks in open country, in stubblefields, pastures and open woodland. It is frequently met with on highways, feeding on the undigested grain which it finds in the horse droppings, or taking a dust bath. It is commonly found nesting in orchards or shade trees, or among ornamental shrubbery of the home grounds, sometimes venturing even into towns. This species, unlike its now probably extinct congener, the Passenger Pigeon, never nests in colonies, and for this reason has been spared 
the fate of its relative. At one time the Passenger Pigreon was so numerous as to obscure the sun while passing over; the slaughter of this species, cruel as it was relentless, was inspired by the same selfish motive that is threatening extinction to several species of plume and game birds, and that likewise all but exterminated the Bison of the western plains. The Mourning Dove was once on the list of permanently protected species, but can now be lawfully shot from September first to December fifth. Considered from an economic point of view, it is too valuable a species to be shot for food. Of its food, 99 percent is seeds, 32, percent being grain; of the grain, three-fourths is waste, picked up in the fields after harvest. Weed seed forms the principal and almost constant article of diet for all seasons, and constitutes 64 percent of the food for the entire year. One stomach examined, contained 7,500 seeds of the yellow wood sorrel (Oxalis stricta), another 6,400 seeeds of barn grass or foxtail (Chactocoloa), and a third 9,200 seeds wade up of a mixture of seven kinds of plants, part of which were noxious weeds, and none of them of use to man. The seeds of many weeds, not commonly eaten by other birds, are destroyed by the Mourning Dove.

\section{QUAIL AND GROUSE}

The Gallinaceous, or scratching birds, are the most prized of game birds. They are very largely terrestrial; being short-winged, they depend more on their protective coloration to escape their enemies than on their power of flight, though strong and swift of wing for short distances. Except when pursued by an enemy, they seldom perch in trees. The eyes of the young are open, when hatched, and they leave the nest very soon after they are out of the shell. During the breeding season they are found in pairs, but later in the season, small flocks or coveys, consisting usually of the members of one family, are met with. The Wild Turkey, once abundant, but now probably extinct in the state, is the largest of the group. The Ruffed Grouse and the Quail are the only representative species, native to the state. Both these species were abundant in past years, but unfavorable conditions and slaughter by hunters has very materially reduced their numbers.

ВОВ-WHITE, Colinus virginianus virginianus (Linn.)

This species, also known as Quail or Partridge, is now only locally common and is gradually but surely diminishing in numbers. The destruction of this valuable species would be an economic loss to the farmer, and the familiar bob-white call would be greatly missed in rural communities. These birds frequent weedy fields bordered with briars, or the undergrowth of woodland, where they feed under 
cover; they roost in the open, forming a circle, tails together and beads out. The young vacate the nest as soon as hatched, sometimes with a piece of the egg-shell adhering. At the approach of danger, the mother bird utters a call which the young know to signify danger, and all immediately hide among the leaves or flatten themselves against the ground where they are difficult to discover. Although hardy, their numbers sometimes suffer heavy loss during unusually severe winters, when snow and ice seal up their food supply. At such times, they frequently seek food and shelter about hay or straw stacks, even coming to the barnyard where they have been known to feed with the chickens. When thus threatened by staryation, coveys can be saved by scattering chaff and grain where they will find it. This entails but little expense or trouble, and will be fully recompensed the following summer by the destruction of noxious insects.

The character of the food varies with the season; the vegetable predominating in winter and the animal in summer. Seeds, fruit, leaves, buds, tubers, insects, spiders, myriapods, crustaceans, mollusks and even batrachians are eaten. About 83.59 percent of the total food is vegetable matter, of which 17.38 percent is grain; 52.83 percent weed seeds; 9.57 percent fruit and 3.8 percent miscellaneous. Of the 16.41 percent animal matter, 6.92 percent consists of beetles; 3.71 percent of grasshoppers; 2.77 percent of bugs; 3.01 percent of caterpillars, spiders and other invertebrates. Many injurious insects are taken, most important of which are: potato beetle, May beetle, both the spotted and striped cucumber beetles, cutworms, tobacco worm, army worm, clover weevil, click beetles, grasshoppers and chinch bugs. The seeds of many noxious weeds are also eaten. As this species feeds among cultivated crops, it is of more than ordinary economic value to the farmer, and he should demand the protection of so valuable a bird the year round.

\section{RUFFED GROUSE, Bonasa umbellus umbellus (Linn.)}

This handsome bird is more commonly called Pheasant. It is confined to woodland and is, therefore, very local in its distribution. Through the destruction of the forest and persistent slaughter by hunters, its numbers have steadily diminished until, like the Wild Turkey, extermination seems inevitable. The food is varied and consists of many kinds of insects, seeds, wild fruits, buds and leaves. It is of decided economic value to woodland and, when protected, becomes very tame, and has been known to feed close to buildings, showing little fear of man. 


\section{SHORE BIRDS}

Plovers, Snipes and Sandpipers belong to the group of birds known as Shore Birds and, true to name, they are usually found in the vicinity of water, although a few are to be found on dry ground. The majority of species frequent the shores of large bodies of water, yet a number of species are found along water courses or small inland lakes. As a rule, they are gregariou: A...ing winter. All are classed as game birds. Their food is largely rauz up of the small aquatic forms of animal-life, these being usually a btained by probing the mud with their long, slender, sensitive bills. Between 35 and 40 representatives of this group occur in the state, being most abundant along the lake shore. A few species are common throughout the state.

\section{woodCOCK, Philohela minor (Gmel.)}

The Woodcock has been far too much of a favorite, w a game bird, for its own perpetuation. It was once an abundant infabitant of swampy woodland in all parts of the state, but is now commen in very few localities. It is a bird of crepuscular (twilight) or no:turnal habits and is with difficuity flushed during the day. Except during migrations or in paszing from woods to woods, it is never seen in the open. It is the only bird inhabiting woodland that probes the mud for insect larvaeand earthworms, upon which it feeds. Because of lax laws for the protection of this class of birds, this valuable game bird is rapidly nearing extermination.

SPOTTED SANDPIPER, Actitus macularia (Linn.)

This familiar bird is common throughout the state wherever streams and lakes occur. Its habit of teetering, a habit common to most of the Sandpipers, has caused this species to be called "Tip-up" or "Teeter," while the name "peet-weet" is suggestive of the musical call-note which it atters when surprised. Its usual food is made up of aquatic insects and small animals wbich it picks up at the waters' edge or by wading into the water. Grasshoppers and other land insects which are obtained on cultivated land or pastures, bordering streams, are also eaten.

KILLDEER, Oxyechus vociferus (Linn.)

This species is the commonest and best known of the Plovers as well as of the Shore Birds. Differing from the majority of species of the group, this bird is often found feeding in dry upland fields, although it is of much more frequent occurrence in moist meadows or in the vicinity of water. It is seldom seen alone, but usually goes in small scattered flocks. While feeding, it is a noisy, restless bird, running about in a ne1 vous manner, especially if it knows itself to be 
under human observation. The well known kill-dee note is a familiar sound the greater part of the year. The Killdeer is somewhat nocturnal in habits and its call is frequently heard at any hour of the night. The nest is built in a depression on the ground, usually in a cultivated field or meadow. The young leave the nest soon after hatching. Insects and small, aquatic animal-life constitute the chief diet for this species.

\section{WADING BIRDS}

Rails, Cranes, Herons, etc. are all more or less aquatic in their habits and their distribution depends largely on water. They are most abundant about the larger lakes, but are more or less commonly found along the smaller streams or in marshland. All are largely dependent on aquatic animal and vegetable life for their sustenance; the manner of procuring their food varies greatly among the several families. Some of these birds are of solitary habits, while others are gregarious. Cranes and Storks are rare within the state, but Herons and Bitterns are common where environments are suitable.

GREEN HERON, Butorides virescens virescens (Linn.)

This little Heron is the most familiar species of general distribution in the state. It frequents alike the larger water courses and the smaller streams, both of open and of wooded districts. The nest, constructed of sticks, is situated in the top of a tree in a thicket near water, or not unfrequently in an orchard. Its food is mainly tadpoles, small frogs and other water animals and insects, which are captured by careful stalking, or by remaining motionless until the victim is within striking distance. Its only note is a harsh squawk which is uttered when surprised.

GREAT BLUE HERON, Ardea herodias herodias (Linn.)

At one time a common summer resident, but with the clearing and draining of large tracts, where formerly large numbers nested, it is now found only in a few favoredlocalities and is nowhere common. It is the largest of our Herons and is commonly, but wrongly called, Blue Crane. When in flight, the Herons and Cranes may be distinguished from each other by remembering that the former draw their folded necks between their shoulders, whereas the latter stretch neck and legs at full length.

\section{WATER-FOWL}

In former years, Water-fowl of many kinds were abundant, but advancing civilization, with its attendant train of unfavorable and disastrous conditions, has deprived us of a few species, while many 
more have become rare and all greatly reduced in numbers. The chief causes for this are: the draining of swamps, thus depriving them of nesting and feeding grounds; clearing of the forests, resulting in an irregular and diminished water supply; and last, but not least, the merciless slaughter by hunters for plumage, sport or food. The abolishment of spring shooting of all water-fowl enroute to their breeding grounds, would result in their material increase; many species that now occur only as migrants would then nest in favorable localities.

\section{GREBS AND LOONS}

Among the most aquatic of water birds are the Grebs. Their legs are placed so far back that they are unable to walk and are, therefore, almost helpless on land. In the water, their movements are peculiarly easy and graceful; they swim on the surface or beneath it with equal ease. Their food is composed of a variety of aquatic life, both animal and vegetable, but the main item is fish, which they pursue and capture under the water. The Pied-billed Greb is the best known of the family, occurring throughout the state as a migrant wherever conditions are favorable. In certain localities, it is said to nest sparingly. This species is known by a number of names, Dabchick, Water-witch, and Hell-diver, being the most common. Like all Grebs this one has the power of swimming under water, with only the bill above the surface. Its sudden and mysterious disappearance, when threatened from any quarter, is thus easily accounted for.

The Loons are expert swimmers and divers, only resorting to land to nest. Their progress on land is slow and labored, and is accomplished by the aid of bills and wings. Their food is largely fish, which they pursue and catch by the aid of their feet alone. Loons are not common, but occur irregularly as migrants, being most frequent after severe spring storms. The common Loon (Gavia immer) is the species of most frequent occurrence.

\section{GULLS AND TERNS}

The long-winged swimmers, the Gulls, Terns, etc.are most commonly met with along the Lake shore, but they not infrequently occur inland on lakes and the larger streams. Both Gulls and Terns feed on fish, which they catch alive or find dead; garbage is also eaten. As scavengers, they are of great service to man, since they rid the water and shore of decaying matter which would otherwise pollute both water and air. Gulls settle on the water to take their food, and fly with the bill in a line with the body, whereas Terns snatch their 
food from the waves while on the wing, and the bill is held at rightangles to the body while flying. The Herring Gull, Bonaparte Gull and the Common Tern are the species of most frequent occurrence.

\section{DUCKS, GEESE AND SWANS}

The order known as the Anseres, comprising Ducks, Geese and Swans, includes some of our commonestand best known water birds, many of which are highly prized alike by sportsman and epicure. The food of the group, with the exception of the Mergansers, which feed on fish, is chiefly vegetable, both aquatic and other plants being eaten, weed seeds forming a considerable proportion. Between thirty-five and forty species of Ducks, Geese and Swans occur within the boundaries of the state, quite a number of which are rare or of local distribution.

MALLARD, Anas platyrhynchos (Linn.)

This is the best known of our ducks, occurring commonly during the migrations and breeding sparingly where conditions permit. It is among the earlier ducks to arrive in the spring, generally reaching us in March, following the breaking up of the ice. The common domesticated ducks originated from this species.

GREEN-WINGED TEAL, Nettion carolinense (Glem.)

The smallest of the ducks and not uncommon as a migrant, occurring at the same time as the preceding species. Much of its feeding is done on land.

BLUE-WINGED TEAL, Querquedula discors (Linn.)

This species is slightly larger and less hardy than the preceding. It is among the latest of the migrating ducks, appearing about the middle of April and returns south early. Pairs are most commonly seen in spring, but it is more abundant in the fall, occurring in small flocks.

PIN-TAIL, Dafila acuta (Linn)

A common spring and fall migrant, wintering in the southern portion. They are most numerous in the fall, but the flocks at this season are much smaller than in the spring. They feed in the shallow water by standing on their heads, searching the mud of the bottom, their tails alone being visible. The flesh is of excellent flavor and, because of this, the species is much sought byohunters; consequently this duck is extremely wary of man.

WOOD DUCK, Aix sponsa (Linn.)

The most beautiful of American ducks, and is probably not surpassed in brilliancy of plumage by any known. It was once the most abundant breeding species in the state, but is now a rare bird, 
most frequent as a migrant. It may possibly breed in a few localities, but no nests have been reported in recent years. The habits of this duck are different from any other. It frequents protected pools and streams, in or near woodland. Its food comprises many forms of aquatic life, both animal and vegetable, besides which, insects, beech-nuts, acorns, etc., are taken in woodland. It perches in trees and nests in cavities of trees, sometimes at a considerable distance from water. This valuable and béautiful species is rapidly nearing extinction.

CANVAS-BACK, Marila valisineria (Wils.)

Because of its finely flavored flesh, especially while feeding on wild celery, this species has probably been more persistently hunted than any other duck. It is now a rare bird in the state.

LESSER SCAUP DUCK, Marila affinis (Eyt.)

Of all our ducks, this species is probably the most numerous. It occurs, during the migrations, in flocks composed of a few individuals to more than a hundred. They are wary of man, except where protected. This little duck may breed in certain localities in the state.

CANADA GOOSE, Branta canadenszs canadensis (Linn.)

This species is commonly known as the Wild Goose, but is no longer the abundant species it once was in Ohio. It occurs in the north as an irregular migrant, and locally in the southern part as a winter resident.

\section{SWANS}

Two species of swans occur in the state, as rare and irregular migrants - the Whistling Swan and the Trumpeter Swan. The latter is the larger and less frequent of the two. Both were much prized as table birds in former years when they were abundant. It is a deplorable fact that these noble birds cannot alight on the waters of lakes or streams, within the limits of populated territory, without being molested. The occurrence of these or of any other large or unusual birds in a neighborhood is almost certain to immediately draw forth all the hunters and guns in the vicinity, and small is the chance that the unoffending visitors will escape with their lives.

\section{MIGRATION RECORD, 1901-1911 INCLUSIVE}

The Junior writer's migration records, covering a period of 11 years, are given in the subsequent tables. Because he was not always able to be in the field at the right time, the dates have, in a few instances, resulted somewhat irregularly, but a fair average can be calculated in most cases. 
In order to avoid confusion of common names, each species discussed in the tables is followed by the number assigned it in the American Ornithologists' Union 'check list. In the columns headed 1901 , 1902, etc., to 1911, are given the records for each year concerning the first appearance of each species; thus 8-10 should be read August 10th. In the column headed, Wayne County, are given the data collected by the Junior. Author and by Messrs. Good* and Oberholser, ${ }^{* *}$ relative to the seasonal occurrence of each species in this locality. In the last column is indicated the earliest appearance of each species for the entire state, these dates being based chiefly on Dawson's Birds of Ohio.

* Ohio Experiment Station, Bulletin No. 198-Spring Manual of Practice in Economic Zoology.

** Ohio Experiment Station, Technical Bulletin No. 4-A Preliminary List of the Birds of Wayne County, Ohio. 


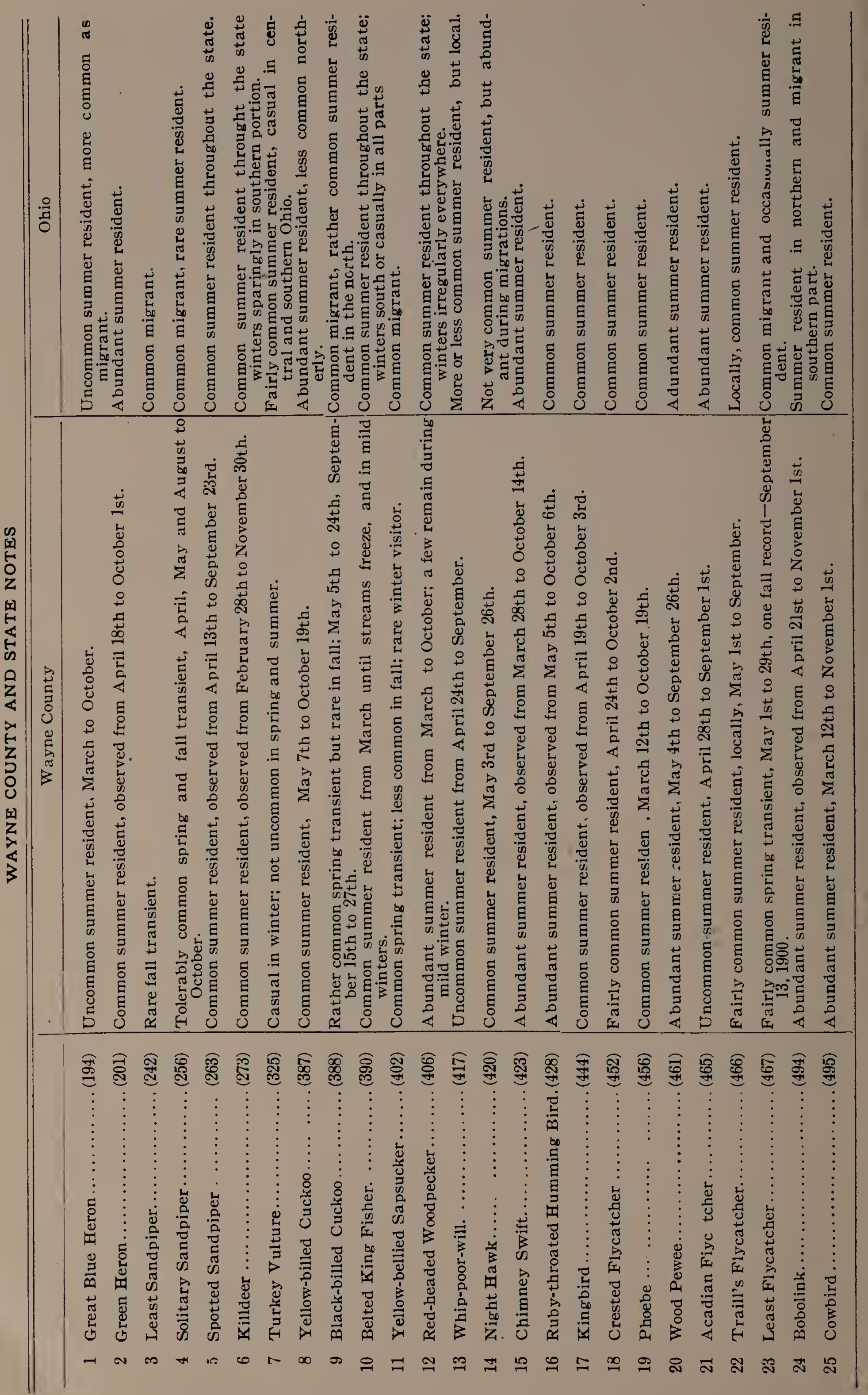




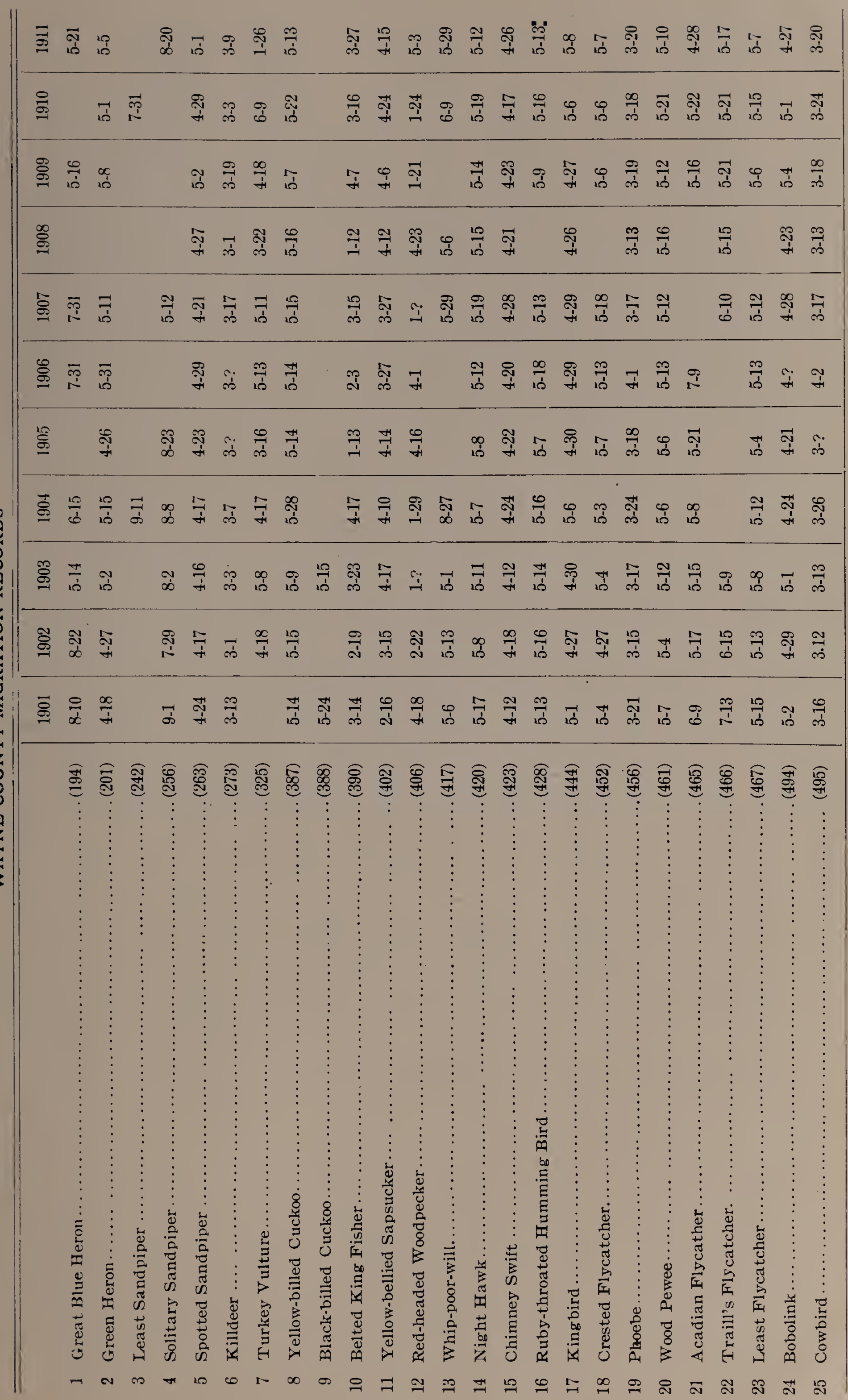




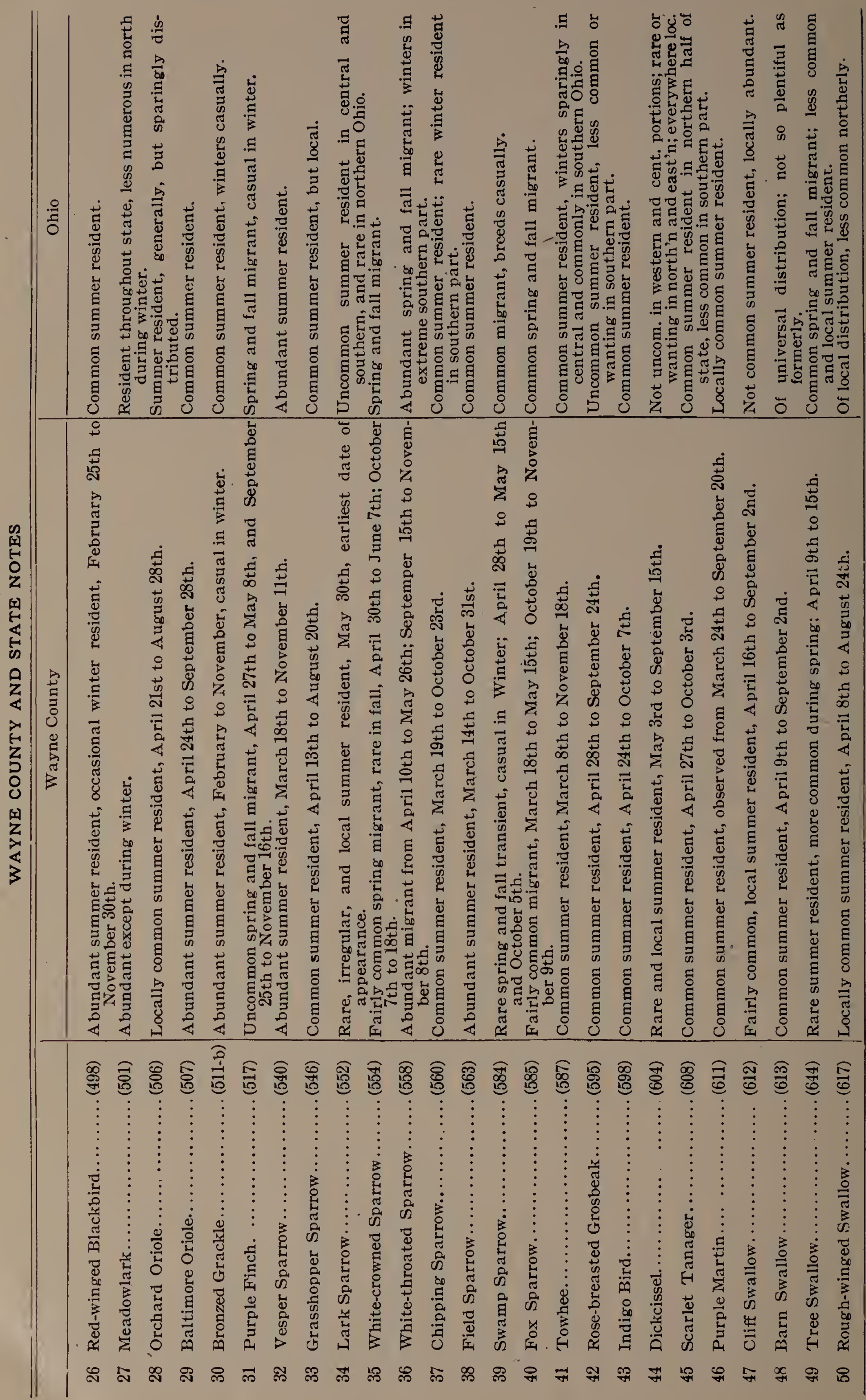




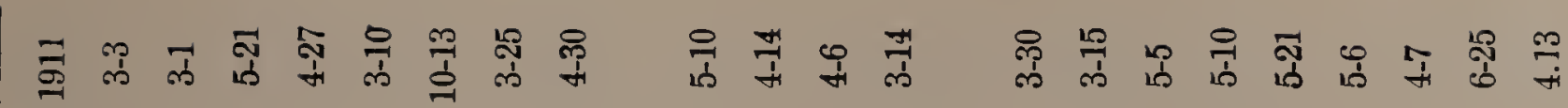

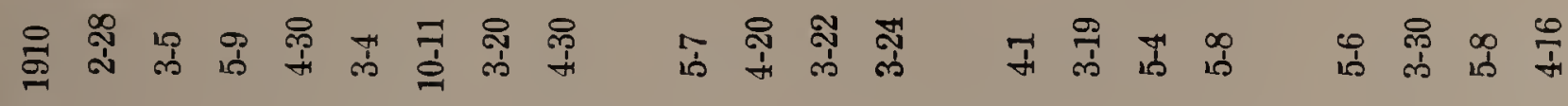

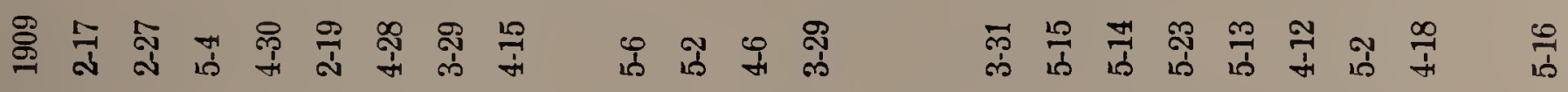

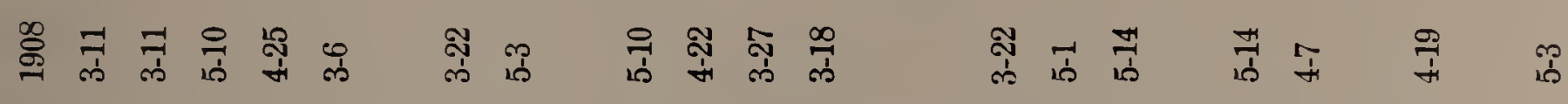

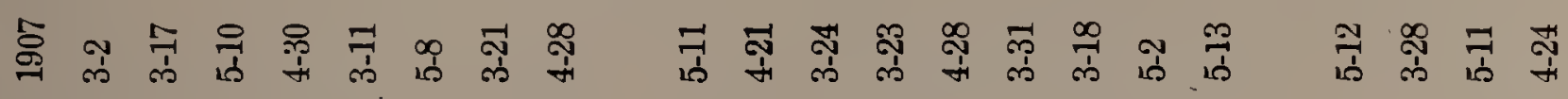

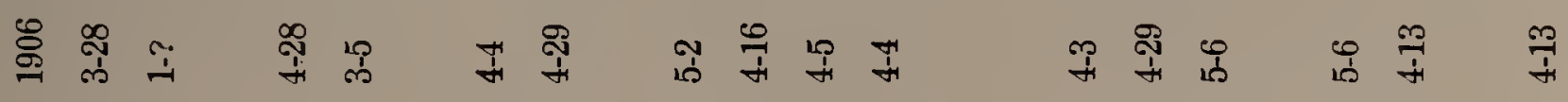

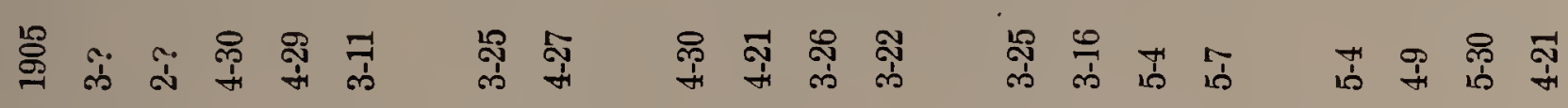

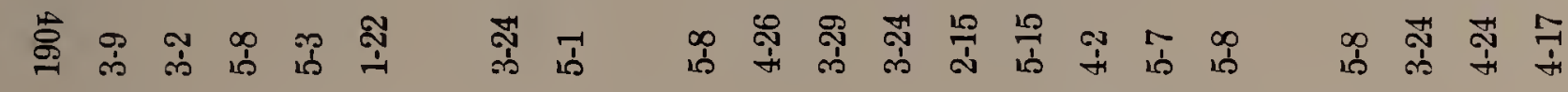

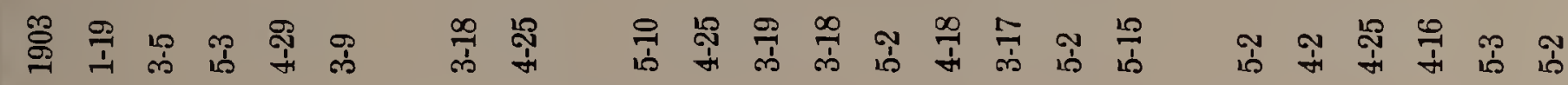

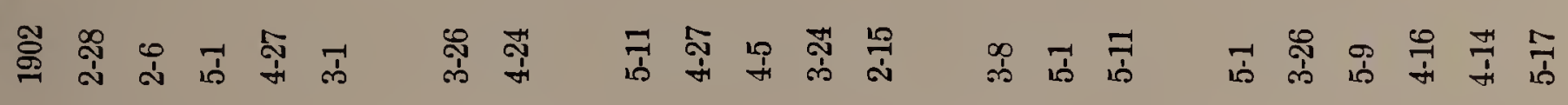

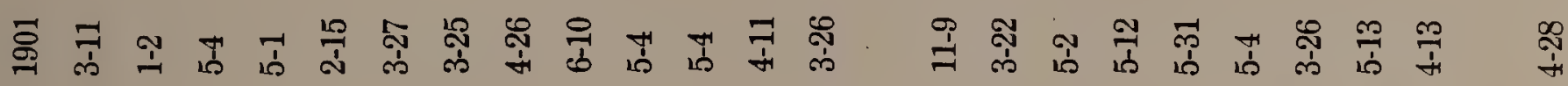

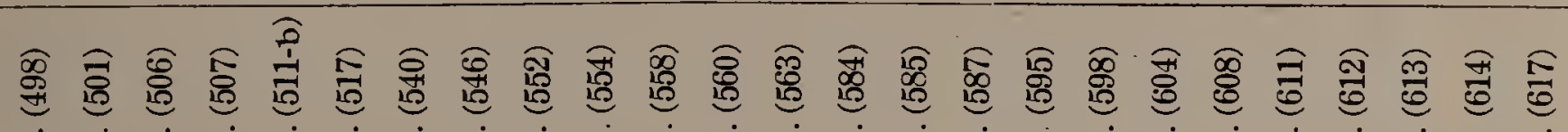




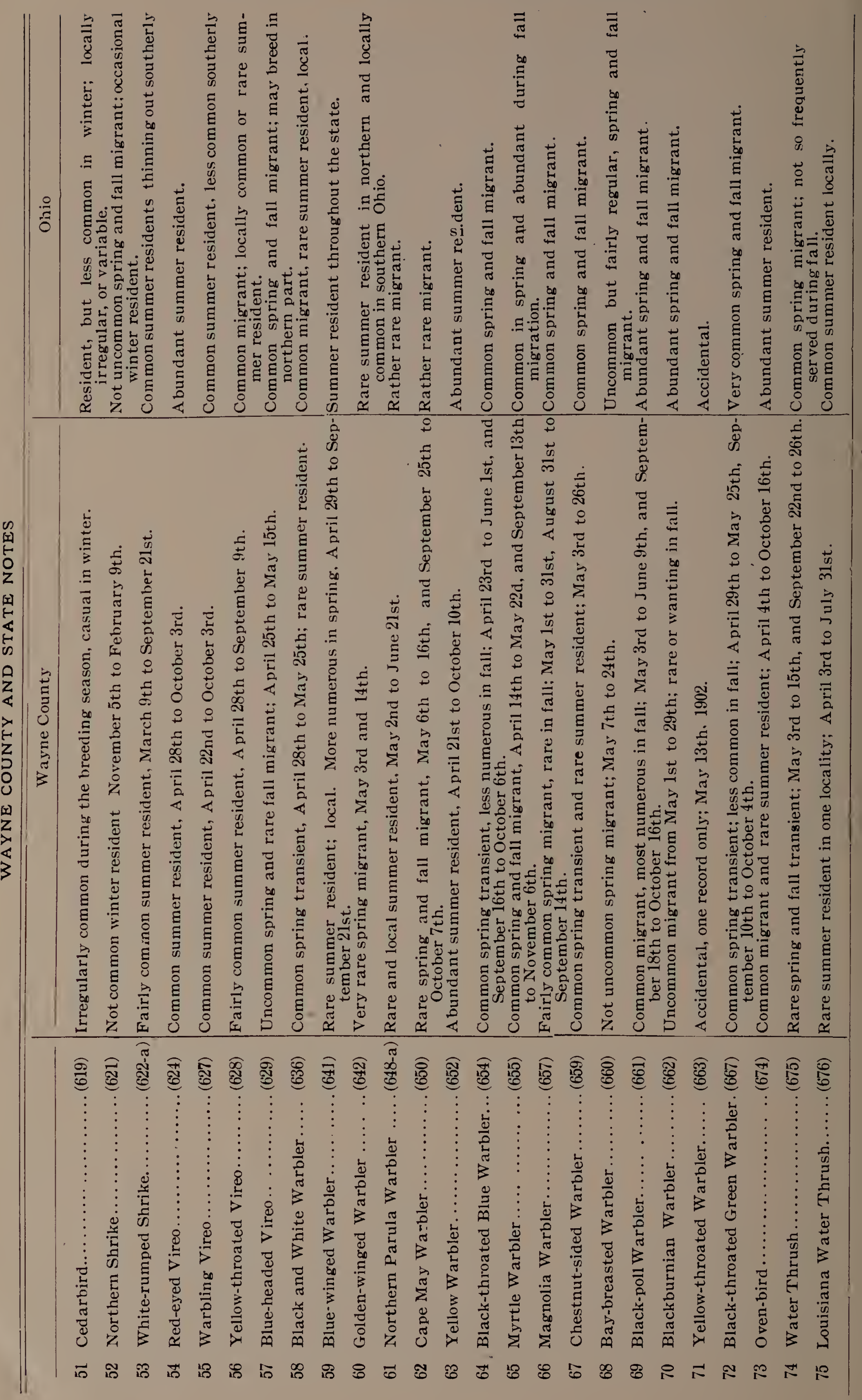




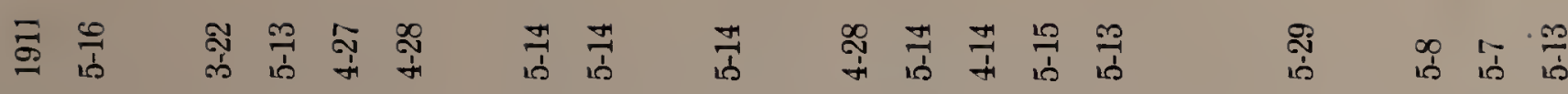

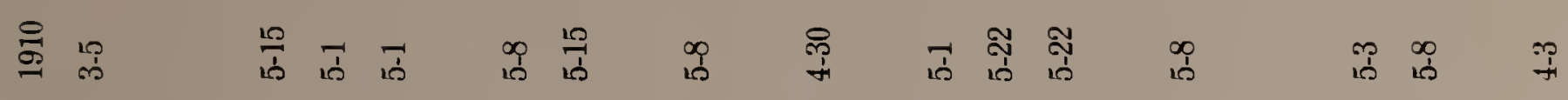

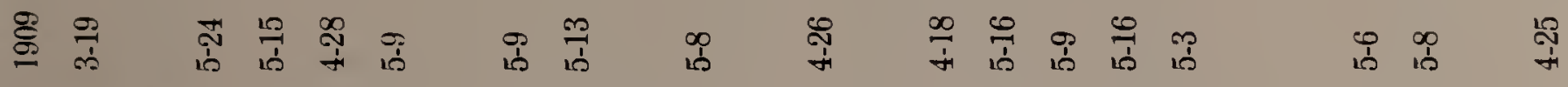

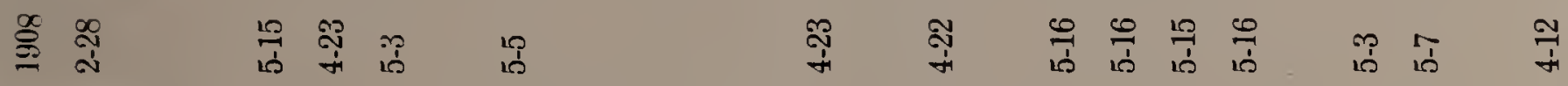

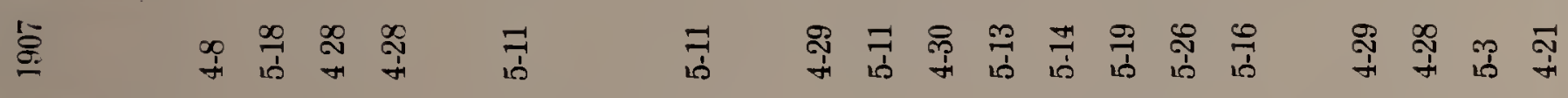

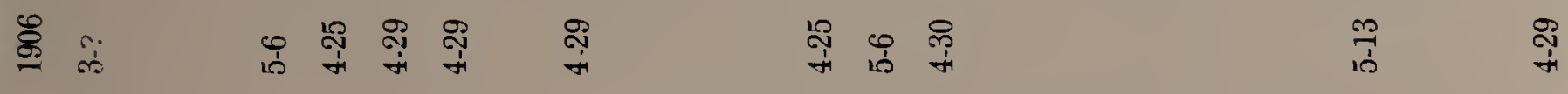

凅

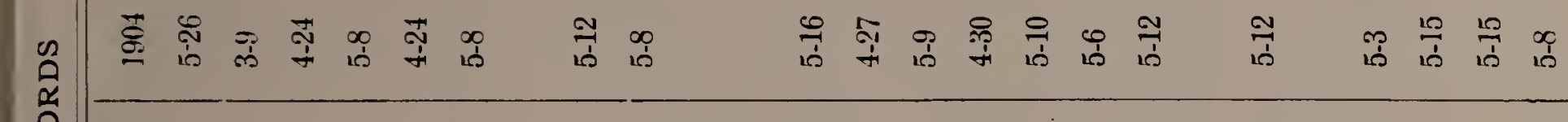

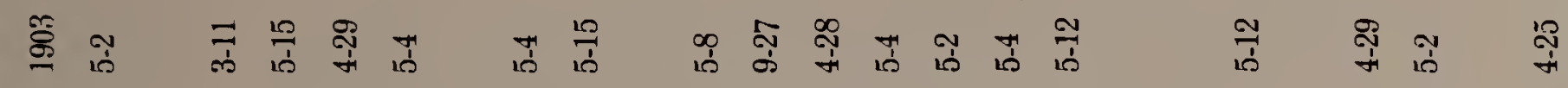

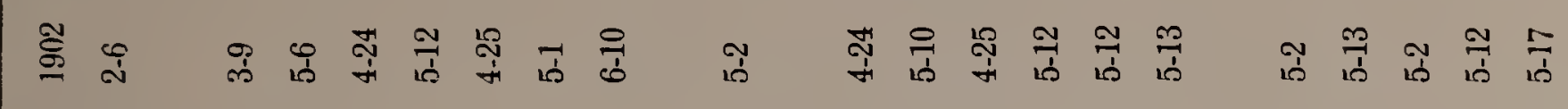

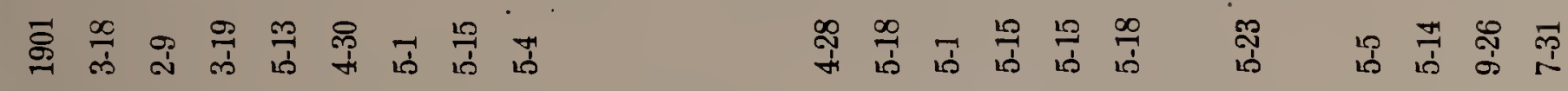

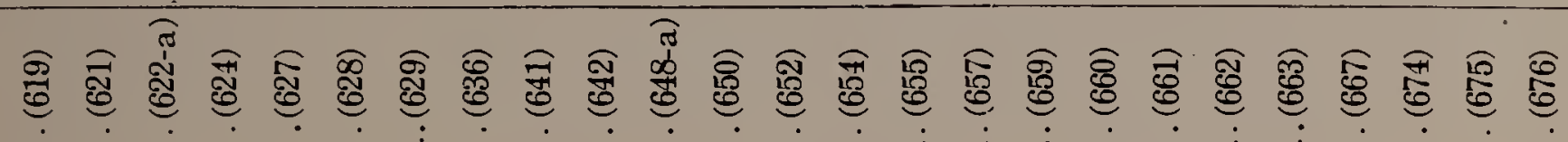

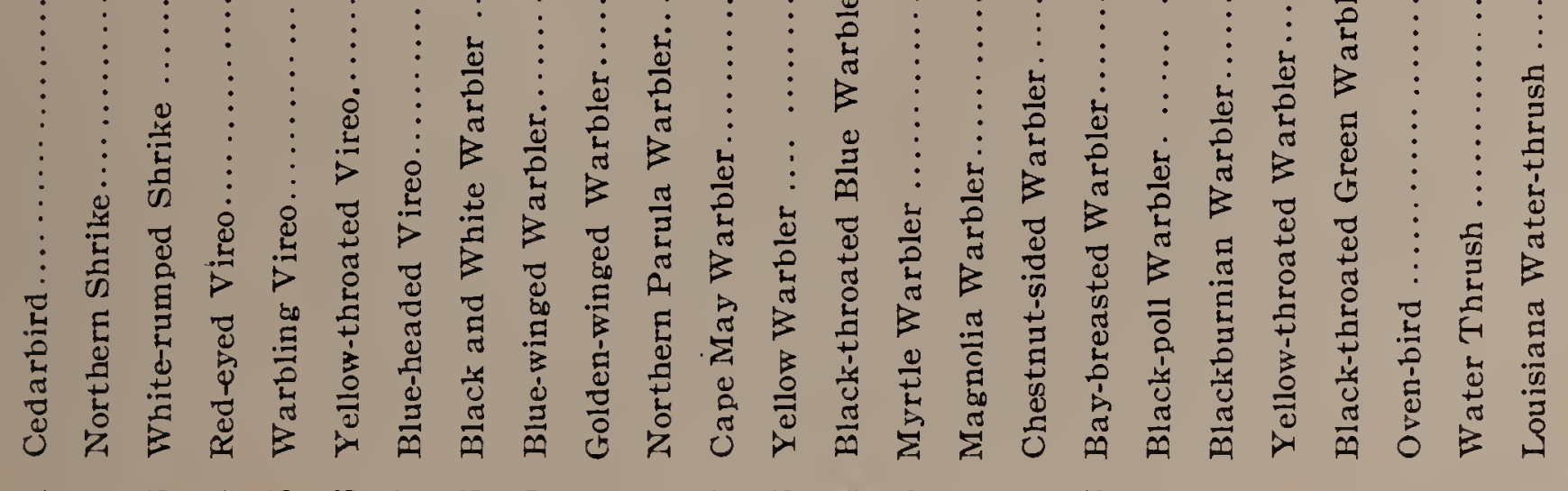

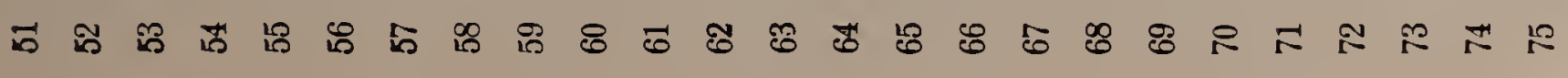




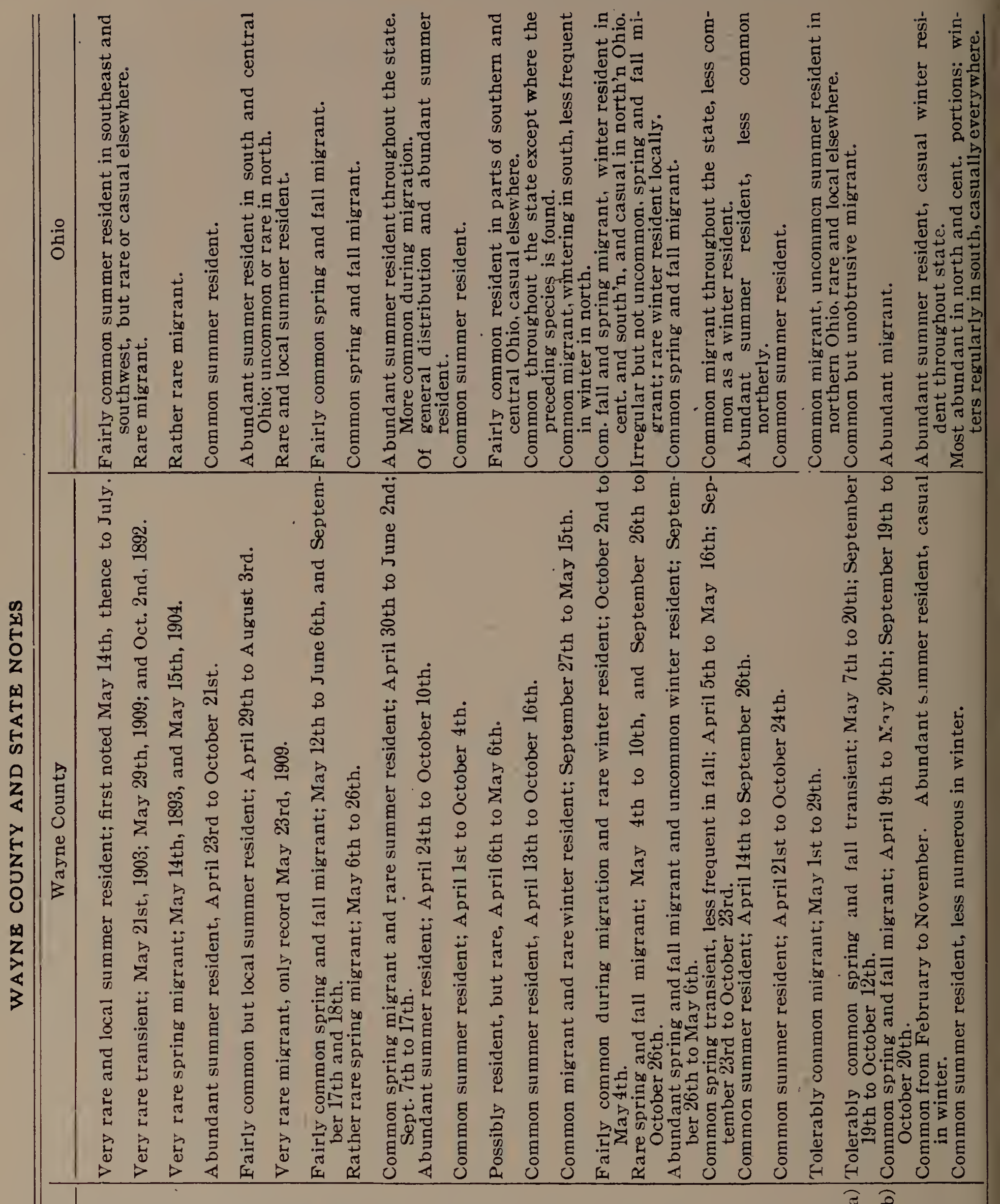

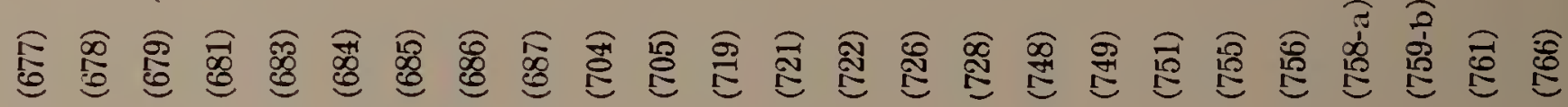

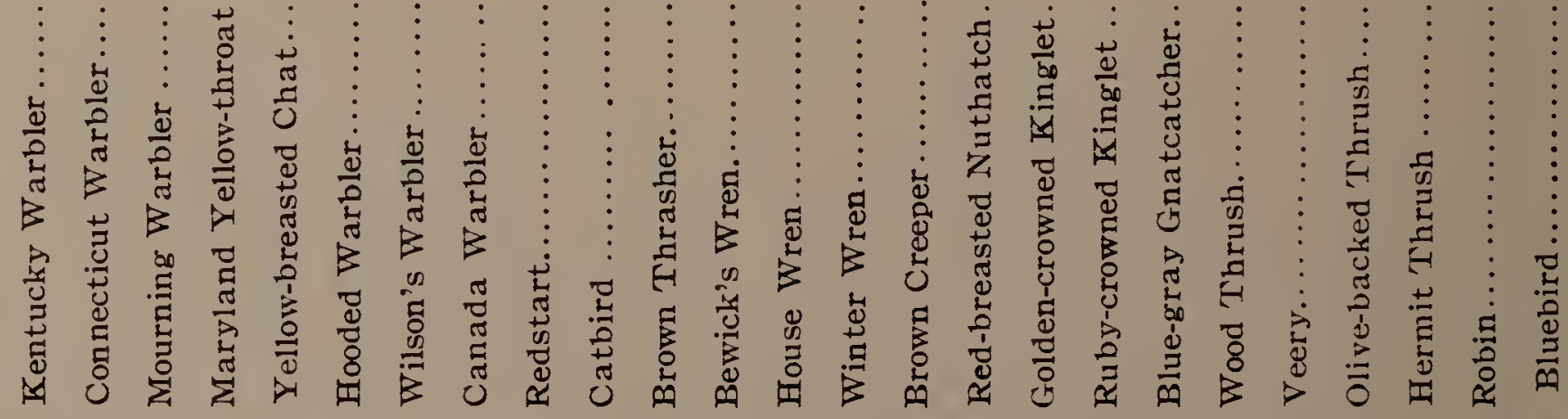

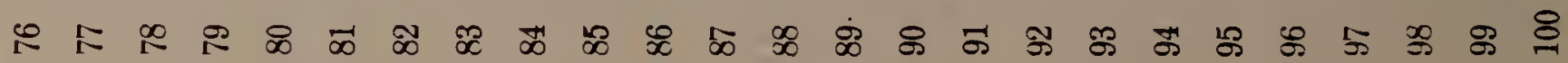




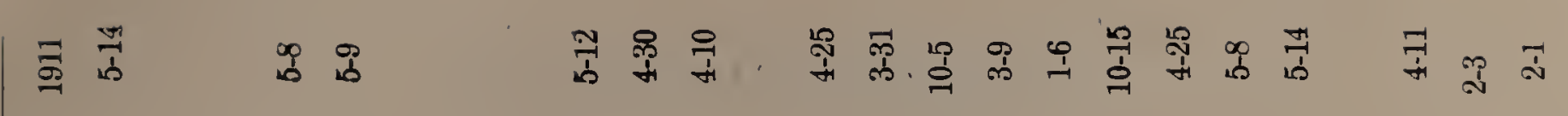

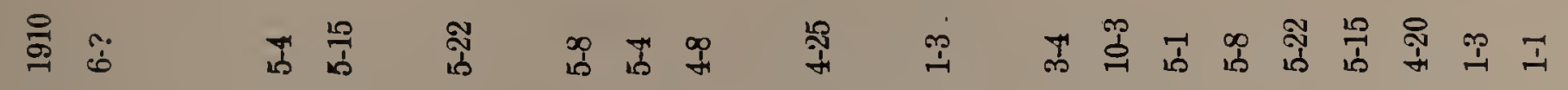

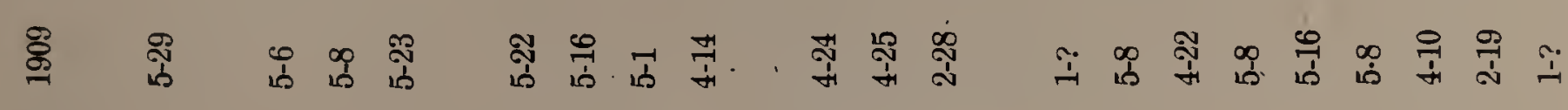

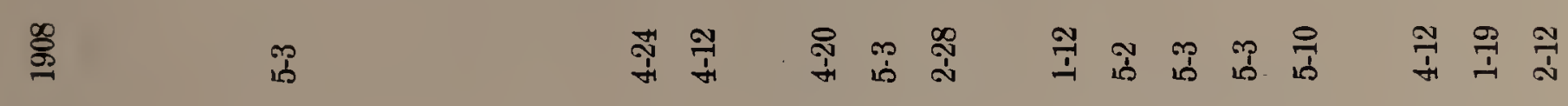

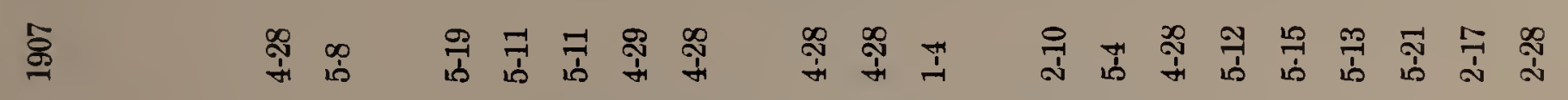

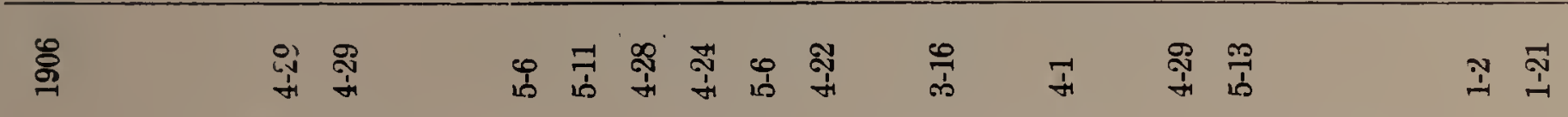

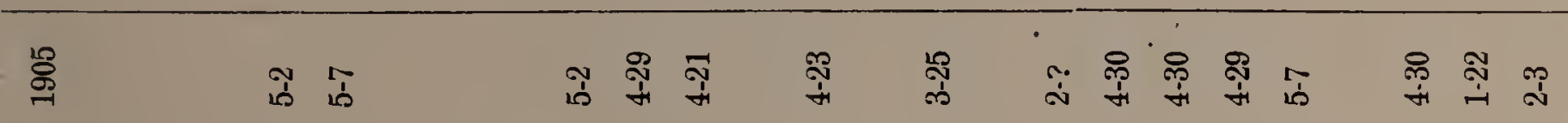

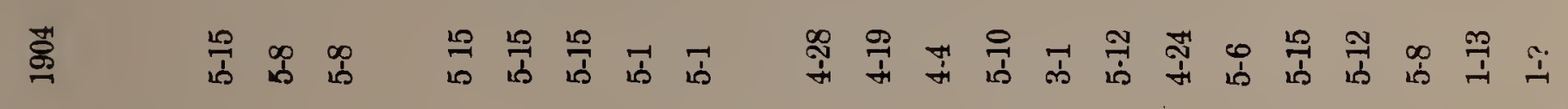

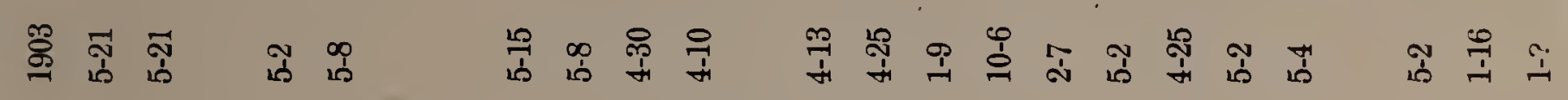

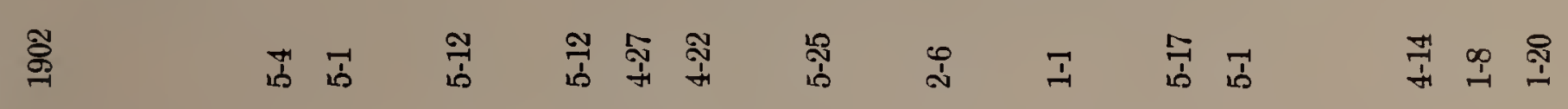

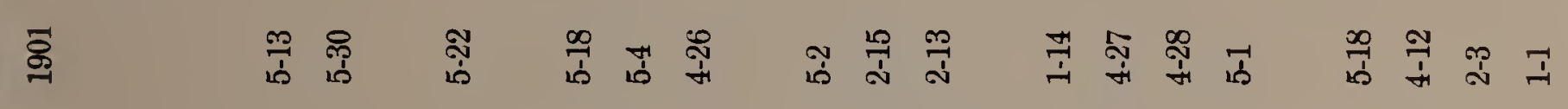

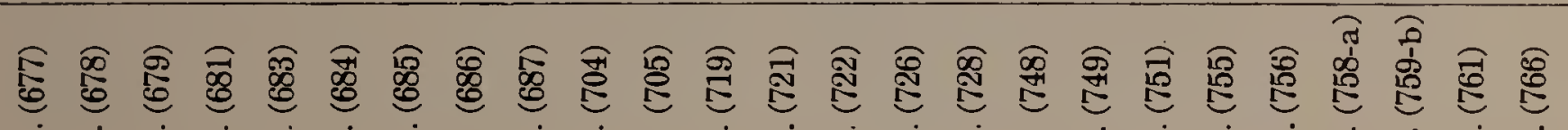

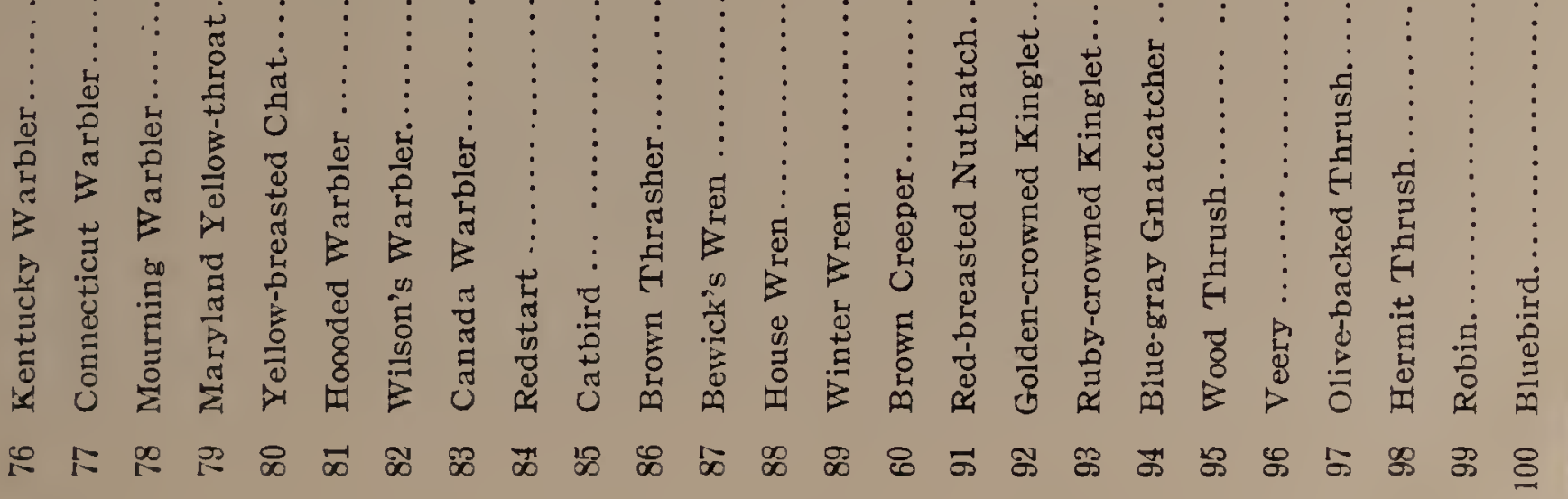




\section{REVISED DATES FOR MIGRATION AND RESIDENT RECORDS FOR SIXTY-THREE SPECIES}

The upper dates, following the name of the species, in the appended list, are from the Preliminary List of the Birds of Wayne County, O. These dates represented our knowledge of the extreme time limits for the occurrence of the listed species at the time of publication. The lower dates are revisions, agreeing with our present knowledge, and extending the time earlier or later for both spring and fall.

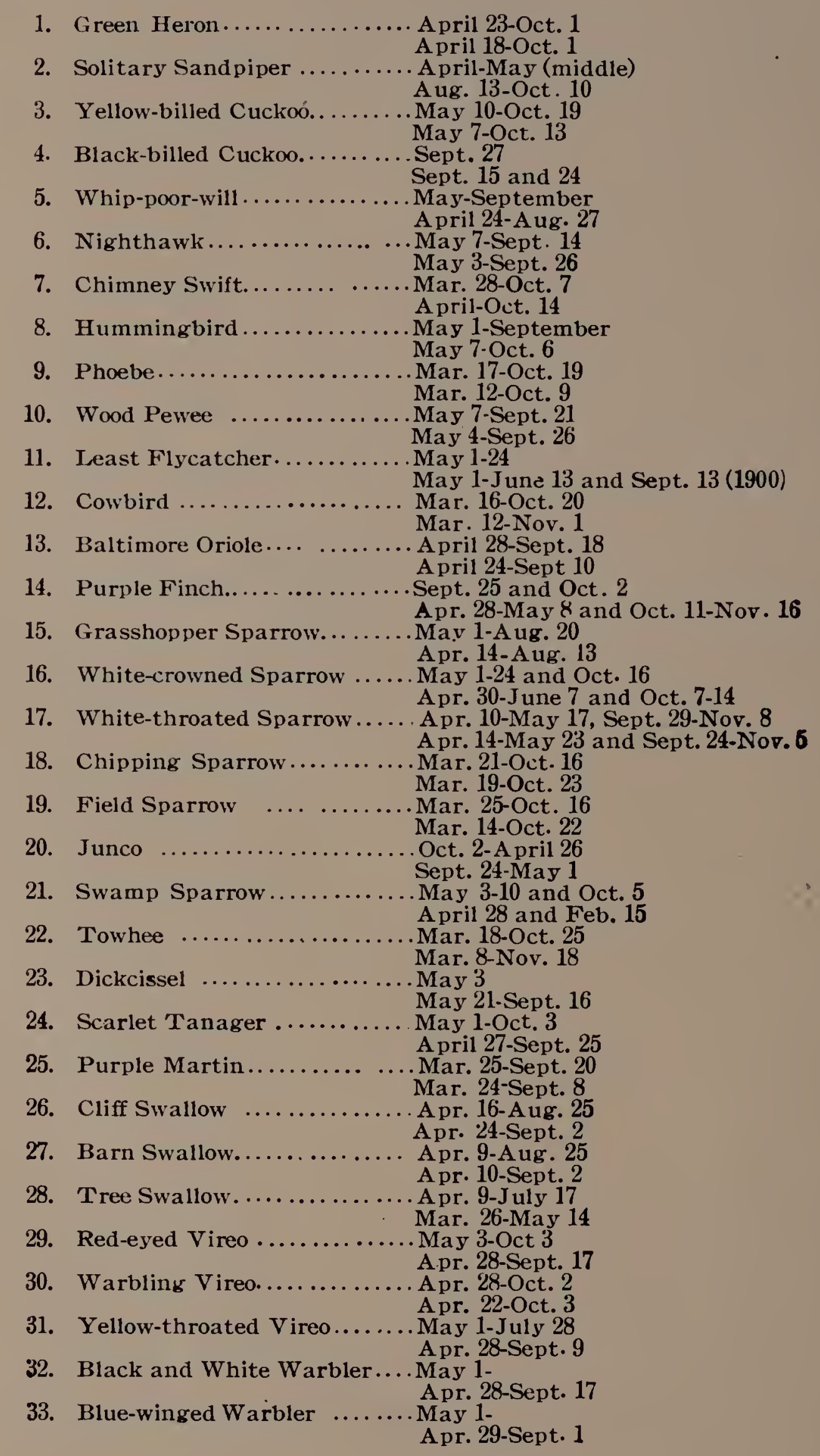




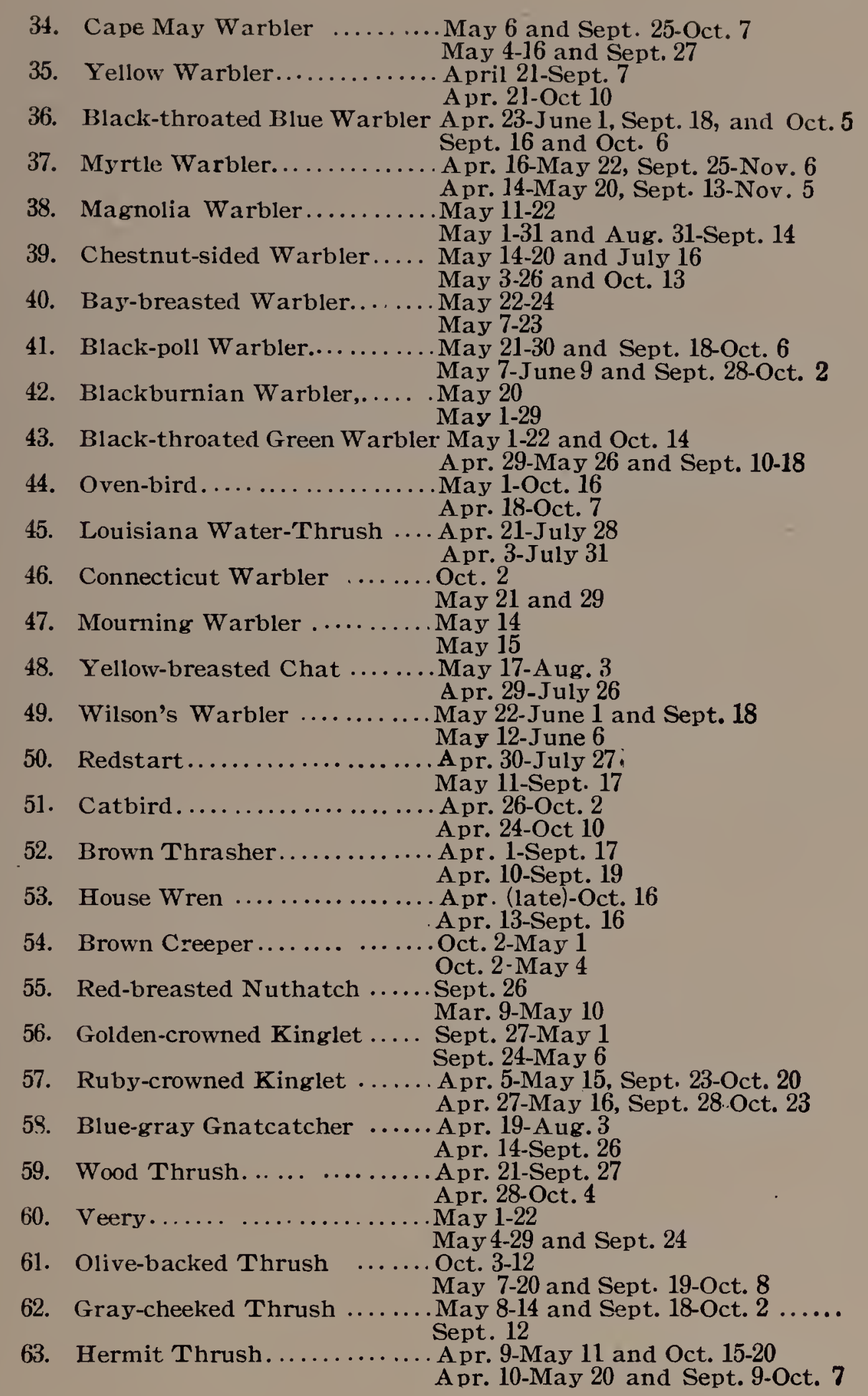

\section{ACKNOWLEDGMENTS}

We are under special obligations to Director John M. Clarke of the New York State Museum and to Mr. Louis Agassiz Fuertes for permission to copy the color plate of Bobwhite from the New York State Museum Memoir 12, and to Mr. Frank M. Chapman, Editor of Bird Lore for permission to use the cuts credited to that Magazine; and to the various photographers whose names appear with theillustrations for theirassent to such usage. The photographs of lithographic plates and other cuts, not especially accredited to some one else, were prepared by the station photographer, Mr. W. P. Beeching, Jr. To all of these we hereby express our thanks. 


\section{LIST OF USEFUL BOOKS ON BIRDS}

For those wishing more complete knowledge concerning our native birds, the following books and publications will be helpful.

1 Bird Homes-Dugmore. Doubleday, Page \& Co. $\$ 2.00$ net; $\$ 2.15$ postpaid.

2 Bird Life-Chapman. D. Appleton \& Co., N. Y. $\$ 2.00$ net.

3 Bird-Lore. Published bi-monthly by the National Association of Audubon Societies, Harrisburg, Pa. $\$ 1.00$ per year.

4 Bird Neighbors_Blanchan. Doubleday Page \& Co., N. Y. $\$ 2.00$.

5 Birds Every Child Should Know-Blanchan. Doubleday, Page \& Co., N. Y. $\$ 1.20$ net; $\$ 1.30$ postpaid.

6 Birds in Their Relation to Man-Weed \& Dearborn." L. B. Lippincott Co., Philadelphia, Pa. $\$ 2.50$.

7 Birds of Eastern North America, Hand-book of-Chapman. D. Appleton \& Co., N. Y. $\$ 3.00$ (pocket edition, flexible covers $\$ 3.50$ ).

8 Birds of Ohio-Dawson. Wheaton Publishing Co., Columbus, Ohio (out of print).

9 Birds of Ohio, Catalogue of The-Jones. Published by The Ohio State Academy of Science.

10 Birds of Ohio, Report of The-Wheaton, Geological Survey of Ohio, Vol. 4. (out of print).

11 Bird Studies with a Camera-Chapman. D. Appleton \& Co., N. Y. $\$ 1.75$.

12 Birds That Hunt and Are Hunted-Blanchan. Toubleday, Page \& Co., N. Y. $\$ 2.00$.

13 Bulletins of The Bureau of Biological Survey, Washington, D. C.

14 Camera Studies of Wild Birds in Their Homes-Reed. Doubleday, Page \& Co. $\$ .60$ net; $\$ .70$ postpaid.

15 Camps and Cruises of An Ornithologist-Chapman. D. Appleton \& Co., N. Y. $\$ 3.00$ net.

16 Check List of North American Birds. Published by The American Ornithologists' Union, N. Y. Obtained through the Secretary, J. Dwight, Jr. \$2.75.

17 Color Key to North American Birds-Chapman. Doubleday, Page \& Co. $\$ 2.50$ net; $\$ 2.75$ postpaid.

18 How to Attract the Birds-Blanchan. Doubleday, Page \& Co., N. Y. $\$ 1.35$ net; $\$ 1.50$ postpaid.

19 Life Histories of North American Birds-Bendire. Smithsonian Institution, special bulletin (out of print).

20 Useful Birds and Their Protection-Forbush. Published by The Massachusetts Board of Agriculture, Boston. $\$ 1.36$ postpaid.

21 Warblers of North America, The-Chapman. Doubleday, Page \& Co., N. Y. \$3.00 net.

22 Water-Fowl, Among The-Job. Doubleday, Page \& Co., N. Y. $\$ 1.35$ net; $\$ 1.50$.

23 Wilson Bulletin, The. Published by The Wilson Ornithological Club, Oberlin, Ohio, $\$ 1.00$ per year. 


\section{INDEX}

Acknowledgments.............. 75

American Crow................ 41

American Goldfinch............ 32

Attracting the birds, etc........ 9

Audubon societies.............. 15

Baltimore Oriole. ................ 36

Barred Ow1.................. 50

Barn Ow1.................. 48

Barn Swallow ................. 30

Belted Kingfisher ............. 47

Birds, As destroyers of insects.... 4

and noxious animals.........

Birds, As destroyers of weed seeds.

" consumers of grain, valu-

able insects, etc..............

Bird legislation............. 13

Blackbirds, Orioles and relatives.. 36

Black-billed Cuckoo............. 48

Blackbird, Red-winged ........... 39

Black and White Warbler ........ 24

Bluebird..................... 16

Blue Jay..................... 41

Blue-winged Teal............. 63

Bobolink.................... 40

Bob-white.................. 58

Bronzed Grackle .............. 39

Brown Creeper................. 22

Canada Goose................ 64

Canvas-back ................ 64

Cardinal.................... 35

Carolina Wren.............. 23

Catbird ................... 18

Catching and killing birds other than game birds............. 13

Cedar Waxwing .............. 28

Chat, Yellow-breasted.......... 26

Chickadee..................... 21

Chimney Swift............... 43

Cooper's Hawk................ 53

Cowbird................... 40

Crow, American .............. 41

Cuckoo, Yellow-billed............ 47

" Black-billed............ 48

Disturbing or destroying nests of birds....................... 14

Downy Woodpecker............ 46

Dove, Mourning.............. 57

Drinking fountains and baths..... 12

Ducks, Geese and Swans ........6 63

Duck, Ma1lard...............63 63

“ Green-winged Teal...........6 63

“ Blue ، “ ........66 63

“ Pin-tail .....................6 63

" $\quad$ Wood.......................... 63

" Canvas-back.............6 64

" Lesser Scaup.............. 64

Economic functions of birds........ 3 " treatment of groups and species.................... 15

English or House Sparrow ........ 34
Finch, Purple................ 33

Flicker, Northern ............ 44

Flycatchers .................... 42

Golden-crowned Kinglet ........ 20

Goldfinch, American........... 33

Goshawk.................... 54

Goose, Canada...............6 64

Great Blue Heron.............. 61

Great Horned Ow1............. 50

Grebs and Loons............... 62

Green Heron..................6 61

Green-winged Tea1 ..........6 63

Grosbeak, Rose-breasted......... 36

Grouse, Ruffed.................. 59

Gulls and Terns............. 62

Hairy Wookpecker............. 47

Hawks and Eagles ............ 51

Hawk, Marsh............... 52

“ Sharp-shinned ............ 52

" Cooper's ................... 53

“ Red-tailed............... 54

“ Sparrow............... 55

Heron, Green ..................... 61

Great Blue...........6 61

House Wren.................. 24

Humming-bird, Ruby-throated...... 43

Introduction ................ 1

Junco, S1ate-colored ............ 33

Killdeer................... 60

Kingbird................... 42

Kingfisher, Belted............ 47

Kinglets .................. 19

Kinglet, Golden-crow ned........... 20

Ruby-crowned......... 20

Lesser Scaup Duck............. 64

List of useful books on birds...... 76

Loggerhead Shrike ............. 28

Long-eared Ow1 ................. 51

Mallard.....................6 63

Marsh Hawk.................. 52

Maryland Yellow-throat........ 25

Meadowlark............... 38

Migration record, 1901-1911 inclusive...................6 64

Mourning Dove ................ 57

Myrtle Warbler............... 25

Nesting boxes and devices....... 10

Nighthawk................. 43

Northern Flicker.............. 44

Shrike............ 28

Nuthatches, Chickadees, Creepers

and Wrens................. 20

Nuthatch, White-breasted........ 20

Red " $\quad \ldots \ldots \ldots \ldots 21$

Orchard Oriole................. 38

Oriole, Baltimore ............. 36

"، Orchard.................... 38

Oven-bird.................. 25

Owls...................... 48

Ow1, Barn................... 48

Barred............... 50 
Ow1, Great Horned................... 50

“ Long-eared ........................ 51

" " Screech ............................ 48

" Short-eared ....................... 51

Permit to collect eggs for scientific

Phoebe ................................ 42

Pin-tai1................................. 63

Planting seeds ....................... 6

"، " trees, shrubs, etc....... 10

Martin .......................... 29

Quail and Grouse...................... 58

Red-breasted Nuthatch ............... 21

Red-eyed Vireo .......................... 26

Red-headed Woodpecker............... 43

Red-shouldered Hawk ................. 56

Red-tailed Hawk..................... 54

Red-winged Blackbird............... 39

Revised dates for migration and resident records................... 74

Robin.................................... 17

Ruby-crowned Kinglet.................. 20

Ruffed Grouse .......................... 59

Sandpiper, Spotted..................... 60

Sapsucker, Yellow-bellied........... 45

Scarlet Tanager....................... 30

Screech Ow1. ........................ 48

Sharp-shinned Hawk. . ............ 52

Shore birds................................ 60

Short-eared Ow1.......................... 51

Shrikes................................... 28

Shrike, Loggerhead ................... 28

Northern ..................... 28

Slate-colored Junco ................. 33

Song Sparrow ........................... 33

Sparrows and Finches................ 31

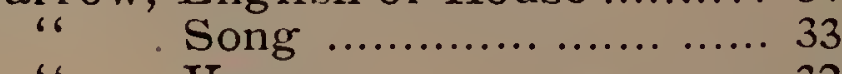

Vesper ..................... 32

Sparrow Hawk......................... 55

Spotted Sandpiper. ... ................ 60

Swallows. .............................. 29 purposes.......................... 14

Planting of shelter belts for winter. 10

Protection from enemies. .............. 12

Purple Finch ......................... 32

Red-bellied Woodpecker ........... . 46

Redstart ................................ 24

Rose-breasted Grosbeak .............. 36

Sparrow, English or House ......... 34

Swallow, Purple Martin.............. Barn...........................

Swan .................................... 64

Tanagers. .............................. 30

Tanager, Scarlet ................... 30

Thrush family ........................... 15

Thrush, Wilson's..................... 18

“ Wood ............................ 18

True Thrushes. ........................ 18

Turkey Vulture..................... 57

Vesper Sparrow ........................ 32

Vireo, Red-eyed......................... .. 26

“ Warbling........................ 27

“ Yellow-throated................... 27

Vultures.................................... 57

Vulture, Turkey..................... 57

Wading birds.......................... 61

Warblers and Vireos ................. 24

Warbler, Black and White ........... 24 ، ، Myrtle .......................... 25 ، Yellow............................ 25

Warbling Vireo...................... 27

Water-fowls............................. 61

Wayne County and State Notes......................66-68-70-72

Wayne County Migration Records....................67-69-71-73

Whip-poor-will ...................... 44

White-breasted Nuthatch............. 20

Wilson's Thrush...... .......... ...... 18

Winter birds...................... 19

Woodcock ........ ........................ 60

Wood Duck.............................. 63

Woodpeckers.......................... 44

Woodpecker, Downy..................... 46

، $\quad$ Hairy................... 47

" $\quad$ Red-bellied................ 46

، Red-headed.............. 44

Wood Thrush.......................... 18

Wrens.................................. 22

Wren, Carolina............................... 23

" House............................... 24

Yellow-bellied Sapsucker.............. 45

“ billed Cuckoo................... 47

" $\quad$ breasted Chat.... .............. 26

"، $\quad$ throated Vireo.................... 27

، Warbler ......................... 25

INDEX OF ILLUSTRATIONS

Barred Ow1 .......................... 50

Bluebird at nest ......................... 16

Catbird on nest...................... 19

Cooper's Hawk ...................... 53

Downy Woodpecker .................. 46

Eagle's nest, Frontispiece

House Wren at nest .................. 23

Making bird homes ................... 11

Red-eyed Vireo on nest.............. 27

Screech Owl, male and female....... 49

Sharp-shinned Hawk ................ 53

Some useful orchard visitors ........ 37

Sparrow Hawk ....................... 56

The Black-capped Chickadee. ........ 21

Yellow-bellied Sapsucker ............. 45

Young Chickadee ......................... 22 
